\title{
PRODUTIVIDADE, MORFOLOGIA, CARACTERÍSTICAS FÍSICAS E VALOR NUTRITIVO DA FORRAGEM DE CAPINS Panicum spp.
}

\author{
JOÃO MENEZES DE SOUZA NETO \\ Engenheiro Agrônomo
}

Orientador: Prof. Dr. CARLOS GUILHERME SILVEIRA PEDREIRA

Tese apresentada à Escola Superior de Agricultura "Luiz de Queiroz", Universidade de São Paulo, para obtenção do título de Doutor em Agronomia, Área de Concentração: Ciência Animal e Pastagens.

P I R A C I C A B A

Estado de São Paulo - Brasil

Dezembro - 2004 
Dados Internacionais de Catalogação na Publicação (CIP) DIVISÃO DE BIBLIOTECA E DOCUMENTAÇÃO -ESALQ/USP

\section{Souza Neto, João Menezes de}

Produtividade, morfologia, caracteristicas fisicas e valor nutritivo da forragem de capins Panicum spp. / João Menezes de Souza Neto. - - Piracicaba, 2005.

$86 \mathrm{p}$. : il

Tese (Doutorado) - - Escola Superior de Agricultura Luiz de Queiroz, 2005

Bibliografia.

1. Capins 2. Crescimento vegetal 3. Forragem 4. Irrigação 5. Morfologia vegetal 6. Mudança climática 7. Pastagens 8 . Plantas forrageiras 9 . Valor nutritivo I. Titulo

CDD 633.2

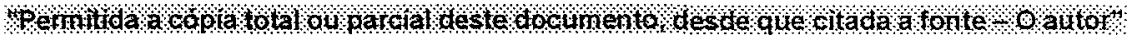

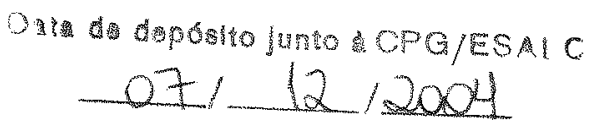




\section{DEDICO}

A Denise, minha esposa, com amor, admiração e gratidão por sua compreensão, carinho, presença e incansável apoio ao longo do período de elaboração deste trabalho.

A Luís Felipe, meu filho, por sua alegria e bom humor em meus momentos mais difíceis. 
"O sacrifício é temporário, o orgulho é para sempre"

Abílio Diniz 


\section{AGRADECIMENTOS}

A DEUS, por guiar o meu caminho e conceder a felicidade de uma família alegre e unida.

À CATI-SAA, por investir em seus funcionários e me conceder licença para realização deste trabalho.

Ao Professor Carlos Guilherme Silveira Pedreira, pela orientação, respeito, amizade, bom humor e presença de espírito.

Ao meu amigo Leonardo Simões de Barros Moreno, pela colaboração, companheirismo e incentivo.

A Waldir Crepaldi, meu sogro, pelo apoio e colaboração.

Ao Professor Luiz Gustavo Nussio pelos ensinamentos, orientações, amizade e apoio durante todo o período que durou este trabalho.

Ao Professor Sila Carneiro Da Silva pelos ensinamentos e amizade.

Aos Professores Wilson Roberto Soares de Mattos e Ricardo Andrade Reis pela colaboração e valiosas sugestões.

Ao Professor Alexandre Vaz Pires, coordenador do PPG - Ciência Animal e Pastagens e a todos os professores do Departamento de Zootecnia-ESALQ/USP. 
A Carla Maris Bittar Nussio e Fábio Prudêncio de Campos pela amizade, boa vontade e empenho na orientação das análises.

À Marília Gabriela Faustino e Vanessa Pillon dos Santos pela ajuda durante as análises.

Aos estagiários Flávio, Vanessa, Cláudio, Adriana, Hugo, Clayton, Guilherme e Diego pela dedicação e empenho.

A César Augusto Alves, Giovana Maria de Oliveira, Creide Ely Martins, Carlos Roberto da Cruz e aos funcionários do Departamento de Zootecnia-ESALQ/USP que contribuíram para a realização deste trabalho.

À Professora Beatriz Appezatto-da-Gloria, Marli Kasue Misaki Soares e Anderson Aparecido de Brito pelo auxílio nas amostras de anatomia.

À Professora Carmen Josefina Contreras Castillo e a Carlota Boralli Prudente dos Anjos pelo auxílio nas análises de resistência ao cisalhamento.

À Regiane Sartorelli pela ajuda na digitação dos dados e Helio Moraes pelas correções de português na versão inicial.

À Eliana Maria Garcia, da Biblioteca da ESALQ/USP pela revisão final do material.

Aos colegas de curso Henrique, Alexandre, Felipe, Lissa, Maria, Daniel Rodrigues, Bruno, Daniel Sarmento, Marco Antônio, Tadeu, Paulo Sérgio, Sérgio, Junio, Lucas pela convivência alegre, constante troca de experiências e conhecimento.

Aos Diretores do EDR-PP Roberto Iassuhico Inague, Fernando Antônio Nunes Carvalho, Norberto Fratini e Ivandeci José Cabral pelo apoio e amizade.

A José Eduardo Creste pelo apoio e amizade. 
À Fundação de Amparo à Pesquisa do Estado de São Paulo - FAPESP, pelo suporte financeiro para execução do trabalho.

A todas as pessoas que direta ou indiretamente contribuíram para a realização deste trabalho. 


\section{SUMÁRIO}

RESUMO

Página

SUMMARY.

$\mathrm{x}$

1 NTTRODUCÃO

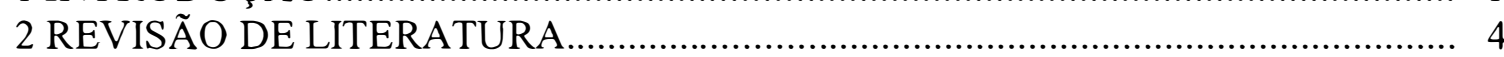

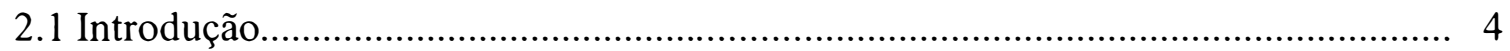

2.2 O gênero Panicum......................................................................................... 7

2.2.1 Origem do gênero Panicum e introdução no Brasil.............................................. 7

2.2.2 Variabilidade genética e cultivares do gênero Panicum...................................... 8

2.2.3 Potencial de produção................................................................................. 9

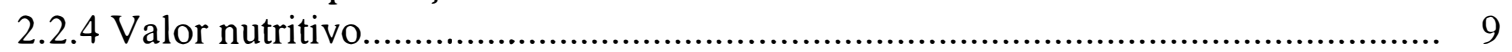

2.3 Efeitos de ambiente e genética na composição químico-bromatológica de plantas

2.3.1 Ambiente.

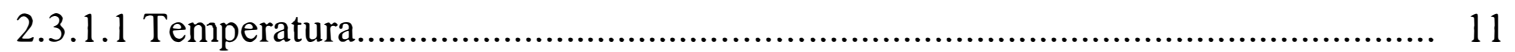

2.3.1.2 Radiação solar................................................................................... 14

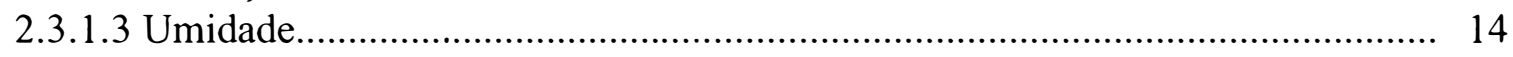

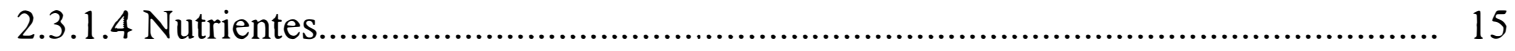

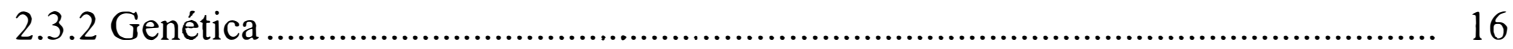

2.4 Crescimento estacional e morfologia de plantas forrageiras.................................. 19

2.5 Caracterização física de forragens.................................................................. 21

2.6 Composição químico-bromatológica...................................................................... 23

3 MATERIAL E MÉTODOS......................................................................... 27

3.1 Local do experimento, dados climáticos, delineamento experimental e

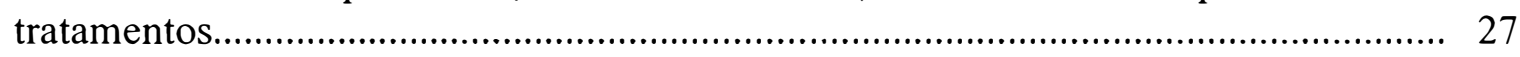

3.2 Amostras de produção............................................................................... 30

3.3 Amostras de acompanhamento da rebrotação........................................................ 32

3.4 Caracterizações físicas de forragem............................................................... 34

3.4.1 Densidade da forragem fresca................................................................... 34

3.4.2 Resistência ao cisalhamento...................................................................... 35

3.4.3 Resistência à moagem................................................................................ 36

3.4.4 Densidade da forragem moída................................................................ 36

3.4.5 Tamanho médio de partícula...................................................................... 37

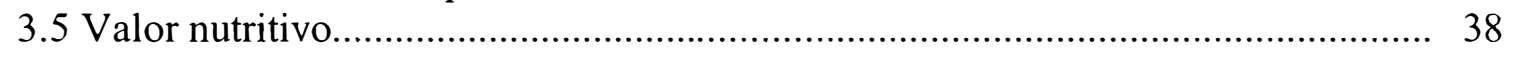

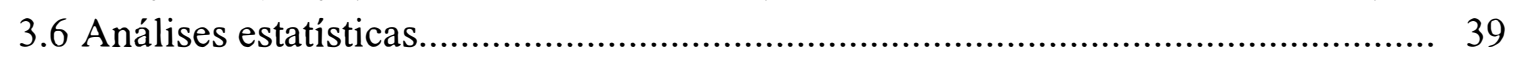


4 RESULTADOS E DISCUSSÃO

4.1 Acúmulo de forragem e composição morfológica de capins de Panicum spp...... 40

4.2 Caracterização física de capins de Panicum spp ............................................... 48

4.2.1 Densidade da forragem fresca.................................................................. 48

4.2.2 Resistência ao cisalhamento..................................................................... 49

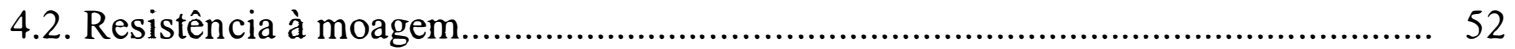

4.2.4 Densidade da forragem seca moída............................................................. 54

4.2.5 Tamanho médio de partículas...................................................................... 54

4.3 Caracterização químico-bromatológica de capins de Panicum spp ....................... 59

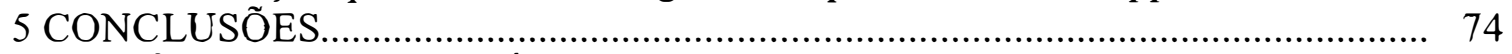

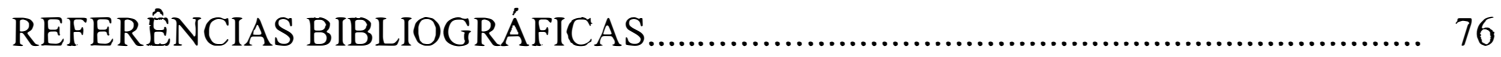




\title{
PRODUTIVIDADE, MORFOLOGIA, CARACTERÍSTICAS FÍSICAS E VALOR NUTRITIVO DA FORRAGEM DE CAPINS Panicum spp.
}

\author{
Autor: JOÃO MENEZES DE SOUZA NETO \\ Orientador: Prof. Dr. CARLOS GUILHERME SILVEIRA PEDREIRA
}

\section{RESUMO}

O desempenho animal em pastagens depende do valor nutritivo da forragem e do consumo voluntário. O manejo visando alto consumo de forragem de alto valor nutritivo exige informações sobre as características morfológicas, físicas e químicas que podem influenciar a ingestão de forragem bem como auxiliar na melhoria do manejo e na eficiência de colheita da forragem acumulada. Este estudo foi conduzido no Departamento de Zootecnia da ESALQ/USP em Piracicaba, SP com o objetivo de caracterizar capins Panicum spp. gerando um banco de dados com informações agronômicas e de valor nutritivo destas forragens, além de características morfológicas, e físicas que possam direcionar a seleção e melhoramento dessas espécies bem como sua utilização em pastagens. Foram utilizados cinco capins Panicum spp. (Atlas, Massai, Mombaça, Tanzânia e Tobiatã) cortados a cada 28 (Atlas, Massai e Mombaça) ou 35 dias (Tanzânia e Tobiatã) no 'verão' (21 de setembro a 22 de março) e 49 (Atlas, Massai, e Mombaça) ou 63 dias (Tanzânia e Tobiatã) no 'inverno' (23 de março a 20 de setembro), a uma altura de 35 (Atlas, Mombaça, Tanzânia e Tobiatã) ou $15 \mathrm{~cm}$ (Massai). Acompanharam-se semanalmente duas rebrotações de 'verão' e, bi-semanalmente, uma rebrotação de 'inverno', caracterizando o acúmulo de forragem e dos componentes da forragem (folha, haste e material morto). A forragem foi caracterizada quanto à sua composição morfológica, características físicas e composição bromatológica. $\mathrm{O}$ capim 
Massai produziu $29 \mathrm{Mg} \mathrm{MS} \mathrm{ha}^{-1} \mathrm{ano}^{-1}$, seguido dos capins Mombaça, Tanzânia e Tobiatã que acumularam em média $20 \mathrm{Mg} \mathrm{ha}^{-1} \mathrm{ano}^{-1} \mathrm{e}$ Atlas $\left(12 \mathrm{Mg} \mathrm{ha}^{-1} \mathrm{ano}^{-1}\right)$. Os capins apresentaram elevada participação de folhas na massa acumulada. A massa de hastes e material morto só aumentou a partir do $10^{\circ}$ dia de crescimento, mas em pequena proporção em relação ao total de forragem em todos os capins $\left(50-100 \mathrm{~g} \mathrm{~kg}^{-1}\right)$. As características físicas variaram quanto à efetividade em tipificar os materiais estudados. Resistência ao cisalhamento $(\mathrm{RC})$, resistência à moagem $(\mathrm{RM})$ e tamanho médio de partículas (TMP) foram efetivas para identificar diferenças entre os capins, diferentemente de densidade da forragem fresca (DFF) e densidade da forragem seca e moída (DFSM). A resistência ao cisalhamento correlacionou-se $(\mathrm{P}<0,05)$ com os teores de proteína bruta $(\mathrm{PB}, \mathrm{r}=-0,47)$, hemicelulose (HEM, $\mathrm{r}=0,40)$, fibra em detergente neutro (FDN, $\mathrm{r}=0,40)$, matéria mineral $(\mathrm{MM}, \mathrm{r}=0,51)$, e com as digestibilidades da FDN (DFDN, $r=0,19)$ e da fibra em detergente ácido (DFDA, r =0,23). O capim Atlas apresentou a maior digestibilidade in vitro da matéria orgânica (DIVMO) (700-730 g kg$\left.{ }^{\mathrm{I}}\right)$, teor de PB (160 $\left.\mathrm{g} \mathrm{kg}^{-1}\right)$ e os menores teores de FDN (680 $\left.\mathrm{g} \mathrm{kg}^{-1}\right)$ enquanto Tanzânia apresentou a menor digestibilidade $\left(665 \mathrm{~g} \mathrm{~kg}^{-1}\right)$ e Massai menores teores de PB (135 g $\mathrm{kg}^{-1}$ ). Os capins estudados possuem grande proporção de folhas, de alto valor nutritivo e altamente contrastantes morfologicamente. O capim Massai foi o mais produtivo e o capim Atlas foi de maior valor nutritivo. Apenas RC, TMP e RM parecem ter sido eficientes para caracterizar fisicamente as forragens estudadas neste trabalho. 


\title{
PRODUCTIVITY, MORPHOLOGY, PHYSICAL CHARACTERISCTICS, AND FORAGE NUTRITIVE VALUE OF Panicum spp. GRASSES
}

\author{
Author: JOÃO MENEZES DE SOUZA NETO \\ Adviser: CARLOS GUILHERME SILVEIRA PEDREIRA
}

\section{SUMMARY}

Animal performance is dependent upon forage nutritive value and voluntary intake. Management directed to high levels of intake of nutritious forage requires information on plant part composition, and both physical and chemical characteristics of the forage on offer, so that quality and quantity of harvested forage can be improved. This study was conducted at the Departamento de Zootecnia, ESALQ-USP, in Piracicaba, SP, with the objective of generating data libraries on the agronomic and quality-related traits of new Panicum spp. grasses, for multiple applications including selection and breeding, as well as optimizing management practices under clipping and grazing. Five Panicum spp. cultivars were clipped every 28 (Atlas, Massai, and Mombaça) or 35 days (Tanzânia and Tobiatã) during the 'summer' (21 Sept. to 22 March), and 49 (Atlas, Massai, and Mombaça) or 63 days (Tanzânia and Tobiatã) during the 'winter' (23 March to 20 Sept.), at a 35 (Atlas, Mombaça, Tanzânia, and Tobiatã) or $15 \mathrm{~cm}$ (Massai) height. Two 'summer' regrowth were characterized by weekly observations and one 'winter' regrowth was monitored bi-weekly. On these occasions, accumulated forage was separated into its morphological components (leaf, stem, dead material) and each fraction was subjected to chemical composition, digestibility, and physical evaluations. Massai 
produced $29 \mathrm{Mg} \mathrm{ha}^{-1} \mathrm{yr}^{-1}$ of forage dry matter (DM), followed by Mombaça, Tanzânia, and Tobiatã (mean $\left.=20 \mathrm{Mg} \mathrm{ha}^{-1} \mathrm{yr}^{-1}\right)$ and Atlas $\left(12 \mathrm{Mg} \mathrm{ha}^{-1} \mathrm{yr}^{-1}\right)$. All grasses yielded leafy forage and stem mass was only measurable $\left(50-100 \mathrm{~g} \mathrm{~kg}^{-1}\right)$ after the 10th day of regrowth. Physical characterization was not a consistently effective tool for describing these forages. Shear strength (SS), resistance to grinding (GR) and mean particle size (MPS) were useful physical descriptors, as opposed to fresh forage density (FFD) and dry ground forage density (DGFD). SS was correlated $(\mathrm{P}<0.05)$ to the forage concentrations of crude protein $(\mathrm{CP}, \mathrm{r}=-0.47)$, hemicellulose (HEM, $\mathrm{r}=0.40)$, neutral detergent fiber (NDF, $r=0.40)$, ash (ASH, $r=0.51)$, as wel as to NDF and acid detergent fiber (ADF) digestibilities $(r=0.19$ and $r=0.23$, respectively). Atlas forage had the highest in vitro organic matter digestibility (IVOMD, 700-730 $\mathrm{g} \mathrm{kg}^{-1}$ ) and CP concentration $\left(160 \mathrm{~g} \mathrm{~kg}^{-1}\right)$, and lowest NDF concentration $\left(680 \mathrm{~g} \mathrm{~kg}^{-1}\right)$. Tanzânia forage had the lowest IVOMD $\left(665 \mathrm{~g} \mathrm{~kg}^{-1}\right)$ and $\mathrm{CP}$ concentration $\left(135 \mathrm{~g} \mathrm{~kg}^{-1}\right)$. All grasses studied yield forage with high proportion of leaves, with high nutritive value, but with contrasting morphological traits. Massai is the highest yielding entry, whereas Atlas gives the highest nutritive value. Only SS, MPS, and GR seem to be adequate for physical characterization of the Panicum grasses used in this study. 


\section{INTRODUÇÃO}

O valor nutritivo de espécies forrageiras tem sido um recorrente objeto de pesquisa dada a sua seleção com o consumo de forragem e com o desempenho animal nos diferentes sistemas de produção. A determinação das características nutricionais da forragem permite o planejamento mais acurado das metas e objetivos a serem atingidos em sistemas de produção em pastagens, pois o conhecimento destas peculiaridades pode indicar o melhor momento de uso das diferentes espécies forrageiras, em cada época do ano e situação de manejo. Além disso, permite prever o desempenho animal, com a utilização de programas de simulação de desempenho, onde a partir do conhecimento do valor nutritivo da forragem consumida, estima-se os resultados de desempenho animal.

A maturidade é o principal fator que interfere no valor nutritivo da forragem. Neste contexto, o ambiente pode afetar a maturidade, modificando a composição química das várias partes da planta, ou atuando sobre a morfologia, como por exemplo, na relação folha:haste (Sinclair \& Seligman, 1995), e no peso de bocados, por alterar a densidade volumétrica da forragem, aspectos que afetam o consumo voluntário de animais em pastejo (Buxton \& Fales, 1994).

Gêneros de plantas forrageiras tropicais como os Panicum spp. precisam ser mais bem avaliados em relação às características nutricionais durante seu crescimento e ao longo das diferentes estações do ano, pois são plantas de desenvolvimento elevado e rápido que sofrem grandes alterações em sua composição morfológica e nutricional durante esse processo. O conhecimento desse comportamento e da dinâmica dessas alterações pode permitir que a forragem seja colhida no momento ideal em situações de manejo adequado. As gramíneas normalmente apresentam maior concentração de parede celular e um acúmulo mais rápido de lignina, quando comparados com leguminosas, o 
que ilustra um maior efeito da temperatura sobre a digestibilidade de gramíneas. Desse modo, as diferenças de valor nutritivo entre leguminosas tropicais e temperadas são menores que entre gramíneas tropicais e temperadas (Wilson, 1982). Buxton e Fales (1994) afirmaram que existe pouca informação sobre os efeitos diretos da temperatura sobre as reações que levam a formação de parede celular das plantas, porém Wilson (1982) asseguraram que o menor valor nutritivo das espécies forrageiras tropicais é um indicativo da influência da temperatura em latitudes mais baixas.

No manejo de pastagens de gramíneas tropicais, eventuais reduções de valor nutritivo são mais rápidas e o conhecimento do ponto ótimo de manejo, com a utilização da forragem no momento de maior valor nutritivo torna-se essencial, pois a partir deste momento, ele diminuirá rapidamente. Uma maior proporção de componentes da planta de elevado valor nutritivo, como as folhas, deve ser objetivo do manejo, pois a composição morfológica das plantas pode influenciar o consumo e o desempenho animal (Euclides et al, 1993). Em espécies de clima temperado, a altura do dossel é tida como o principal fator que influencia tamanho de bocado, mas em espécies forrageiras de clima tropical o consumo por bocado parece ser mais influenciado por porcentagem de folhas, massa de folhas, ou massa de forragem verde na parte superior do dossel (Sollenberger \& Burns, 2001). As diferenças de valor nutritivo entre folhas e hastes e proporção de material morto presente nos diferentes estratos, têm influência marcante sobre a digestibilidade in vitro da matéria seca (DIVMS) da forragem ingerida pelo animal. $\mathrm{O}$ consumo de forragem e o conseqüente desempenho do animal são influenciados pelos atributos da forragem consumida e, portanto, o conhecimento dos aspectos qualitativos da forragem ofertada é importante para o manejo.

Quando a estrutura do dossel, composição morfológica ou valor nutritivo não são suficientes para determinar diferenças de desempenho animal, em dietas de composição semelhante, pode ser que os atributos físicos, raramente quantificados em forragens e que também influenciam o consumo, estejam influenciando a resposta do estudo. Avaliações físicas podem auxiliar na explicação do papel da flora microbiana do rúmen, o que não pode ser explicado apenas pela composição química da forragem, pois a estrutura física da planta pode permitir maior ou menor acesso dos microorganismos aos 
componentes de maior degradabilidade. Dessa forma podem proporcionar um melhor entendimento dos motivos que levam a diferentes taxas de degradação de alimentos de composição semelhante, mas com características físicas contrastantes, que podem favorecer maior ou menor acesso e colonização do alimento por microorganismos ruminais afetando sua degradação (Giger-Reverdin, 2000).

As avaliações nutricionais de espécies forrageiras permitiriam enriquecer o banco de dados para elaboração sistemas de simulação e melhorar previsão de desempenho animal em pastagens, com economia de recursos em pesquisa e melhor planejamento dos resultados obtidos em condições de campo na atividade pecuária.

O objetivo do presente estudo foi quantificar comparativamente o valor nutritivo e as características fisicas de forragem de capins Panicum spp., bem como explicar as variações estacionais das respostas quantitativas e qualitativas, através de atributos morfológicos, químicos e físicos que possam ser afetados pelas variações climáticas ao longo do ano. Além disso, objetivou-se gerar banco de dados com a caracterização químico-bromatológica e física de capins do gênero Panicum sob irrigação. 


\section{REVISÃO DE LITERATURA}

\subsection{Introdução}

A pecuária no Brasil, durante o período colonial, a despeito de sua contribuição fundamental para a vida da colônia, era considerada atividade acessória. As fazendas de pecuária eram localizadas no interior para não disputar as terras férteis do litoral, com pastagens de valor nutritivo inadequado a bons desempenhos animal, em áreas extensas de terra e prejudicadas por fatores climáticos, como as secas prolongadas (Furtado, 2002). Essa filosofia de exploração pecuária continua até os dias atuais, sendo a pecuária de corte pioneira na ocupação territorial no Brasil, ocupando cerca de $20 \%$ da área territorial do Brasil (IBGE, 1998), muitas vezes utilizada mais como reserva de valor que atividade produtiva.

Esse cenário, todavia, não pode continuar, pois assim como a atividade agrícola, que, pressionada pelos mercados internacionais, foi forçada a se ajustar rapidamente, com adoção de tecnologias comparadas às de países desenvolvidos e tornou-se competitiva, essas mudanças chegarão aos empresários pecuaristas de forma a tornar a pecuária tão rentável quanto a agricultura empresarial (Corsi et al., 2004). A intensificação do manejo da pastagem é chave para o processo de aumento da produtividade dos sistemas pecuários e, portanto, fundamental para garantir lucros ao produtor. Assim, o manejo deve ter entre seus objetivos minimizar as perdas e maximizar a eficiência de uso dos nutrientes pelas plantas e pelos animais, garantindo sustentabilidade do sistema produtivo (Dubeux Jr et al., 2004).

O rebanho bovino brasileiro é de aproximadamente 185 milhões de cabeças (IBGE, 2002) e a principal fonte de alimento desses animais são as pastagens, o que 
deve ser encarado como poderosa ferramenta de redução de custos (já que o pastejo é o meio de alimentação mais barato, pois em geral não é onerado pelos custos de colheita, de armazenamento e de fornecimento da forragem), o que reforça a necessidade de se fazer bom uso desse recurso produtivo. $\mathrm{Na}$ sua maioria, entretanto, as áreas de pastagem não são exploradas de forma racional e intensiva. Idealmente, é "chave" que se obtenha elevada produção de forragem e que o animal consiga colher a maior parte da forragem produzida quando esta se apresenta com alto valor nutritivo, a fim de obter consumo elevado e para que o animal possa expressar o máximo de seu potencial genético, possibilitando otimizar a produção vegetal e animal no ambiente de pastagem. A escolha do método de pastejo e o seu manejo são determinantes da quantidade de forragem consumida diariamente por animal, assim como podem determinar a produção subseqüente dos animais e das pastagens, influenciando o desempenho tanto da planta forrageira como do animal (Pedreira et al., 2001). Infelizmente o bom manejo das pastagens não tem ocorrido, principalmente pela falta de profissionalismo de muitos pecuaristas brasileiros, que são agricultores ruins ou não encaram as pastagens como cultura que requer práticas culturais e técnicas de manejo esmeradas. Os sistemas de exploração são na sua maioria empíricos e exploram áreas extensivas, tornando a pecuária brasileira pouco produtiva e pouco lucrativa. É então fundamental, para a reversão dessa situação, que haja incremento (quantitativo e qualitativo) na produção de forragem, não só visando incremento na produção animal, mas também na eficiência do sistema produtivo (Rolim, 1980). A busca de melhor eficiência econômica do sistema deve aliar técnicas adequadas de manejo e planejamento que permitam a tomada de decisão direcionada ao máximo lucro e mínimo de perdas, pois, mesmo sendo explorada de maneira extensiva, a pecuária é uma das principais atividades econômicas do país, geradora de empregos e saldos na balança comercial.

O lançamento de novos capins de plantas forrageiras, associado à recomendação e utilização por técnicos e produtores, respectivamente, muitas vezes sem critérios, tem preocupado e incentivado pesquisadores a procurar determinar o manejo adequado dessas pastagens, através de ensaios de avaliação da forragem e do animal, quando submetidos a diferentes condições edafoclimáticas e de manejo. O manejo adequado das 
pastagens, melhorando sua resposta produtiva, eficiência de colheita e persistência sob pastejo, evitaria que produtores sempre estivessem à procura de espécie forrageira "milagrosa", que acumula grandes quantidades de forragem de alto valor nutritivo, mesmo em solos de baixa fertilidade e manejo inadequado. A simples troca de espécie forrageira no sistema de produção não determina, qualquer melhoria na produtividade animal em longo prazo, a não ser que seja acompanhadas por mudanças planejadas e, de caráter global, no sistema de produção (Lupinacci, 2003).

Mesmo com estes problemas, a partir da década de 1970 houve crescimento significativo da área ocupada por pastagens no Brasil, passando de 147 milhões de hectares em 1970 para 179 milhões em 1984 (Faria et al., 1996). Essa expansão esteve associada ao desbravamento das regiões de Cerrado e da Amazônia, pois, em ecossistemas que já haviam sido intensamente exploradas, ocorreu redução na taxa de expansão de pastos cultivados. No Estado de São Paulo, a expansão da cultura da canade-açúcar (Saccharum officinarum L.) e de citros (Citrus spp) foi realizada principalmente em áreas de pastagens, que, por serem usualmente exploradas em sistemas essencialmente extrativistas e de forma ineficiente, não conseguem competir economicamente com culturas intensivas e de elevada produtividade.

Um dos fatores que afetam a rentabilidade da pecuária é a dificuldade de produtores e técnicos planejarem a atividade. Com isto há, por parte dos produtores e de técnicos, preocupação excessiva com fatores como qual espécie forrageira adotar para atingir determinadas metas de desempenho animal, quando o que freqüentemente falta é conhecimento sobre a espécie já estabelecida e qual o manejo deve ser adotado visando êxito no alcance destas. Por outro lado, informações detalhadas sobre as características quantitativas (produção) e qualitativas (valor nutritivo e aspectos físicos) da forragem são importantes para que os processos biológicos envolvidos nas respostas das plantas forrageiras ao ambiente e suas variações possam ser elucidados de maneira lógica, consistente e racional. 


\subsection{O gênero Panicum}

\subsubsection{Origem do gênero Panicum e introdução no Brasil}

A origem dos capins do gênero Panicum é a África Tropical (Parsons, 1972), sendo encontradas formas nativas até a África do Sul, em margens florestais, como capim pioneiro ocupando o solo recém-desmatado e em pastagens sob sombra rala de árvores. Seu habitat abrange altitudes desde o nível do mar até 1.800 m (Jank, 1995).

Existem controvérsias com relação à data e à forma de introdução de capins do gênero Panicum no Brasil. Segundo Parsons (1972), a introdução no Brasil desses capins (bem como a de outras espécies de gramíneas africanas) se deu durante o período áureo do comércio de escravos africanos para as colônias americanas (século XVIII) quando eram utilizados como cama nos navios negreiros. Outra versão, atribui a introdução desses capins à Tomé de Sousa, no século XVII.

A notável adaptação aos tipos de solo e ao clima brasileiros e características inerentes à plantas do gênero Panicum que lhes conferem a classificação de plantas pioneiras, como a capacidade de utilizar eficientemente altas intensidades de luz associadas com a formação de clareiras na vegetação, desenvolvimento rápido e grande produção de sementes (Dias-Filho, 1995), aliadas à rápida substituição de áreas de floresta da América Tropical por áreas de agricultura (Parsons, 1972) favoreceram a ampla disseminação das espécies de Panicum pelo Brasil. Além disso, atributos como elevadas taxas de crescimento, tolerância à seca e bom valor nutritivo chamou a atenção de pecuaristas, que passaram a implantar grandes áreas de pastagens com capins do gênero Panicum. 


\subsubsection{Variabilidade genética e cultivares do gênero Panicum}

Em extensa revisão à literatura, Jank (1995) descreveu a situação atual dos programas de melhoramento genético de gramíneas do gênero Panicum no Brasil. O caráter apomítico da reprodução da maioria das espécies de Panicum aumenta a importância da coleta de materiais nos centros de origem, a fim de garantir a variabilidade necessária (ou seja, coleções de materiais que representem a variabilidade natural) a programas de melhoramento genético, problema esse atualmente contornado no Brasil pelas diversas introduções de materiais trazidos diretamente da África (como é o caso do capim Aruana) ou desenvolvidos por outros países (como os capins Gatton e Hamil lançados na Austrália e o Tobiatã, lançado pelo ORSTOM - França) e pelo convênio firmado em 1982 entre a Embrapa (Empresa Brasileira de Pesquisa Agropecuária) e o ORSTOM (Institut Français de Recherche Scientifique pour le Développement en Coopération) (Jank et al., 1994), detentor da mais ampla coleção do gênero, colocando-o, frente às demais forrageiras tropicais, em posição de vantagem.

Aronovich (1995) citou vários cultivares já lançados, porém atualmente em desuso como o Colonião (já foi o mais plantado no país, provavelmente a forma como o gênero Panicum foi introduzido no Brasil, originário do oeste africano), Búfalo, Gatton Panic e Green Panic (provenientes da Austrália), Guiné, Makueni (originário do Quênia) e Sempre Verde. Em 1986 e 1988 foram lançados pelo IAC, os capins Centenário e Centauro; em 1990 o Centro de Pesquisas Agropecuárias dos Cerrados (EMBRAPA - CPAC) lançou o cv. Vencedor, no mesmo ano foi lançado pelo Centro Nacional de Pesquisa de Gado de Corte (EMBRAPA - CNPGC) lançou o capim Tanzânia - 1 e em 1993 o capim Mombaça (Jank, 1995) e, mais recentemente foram lançados os capins Massai (em 2001 pelo CNPGC) e Atlas (em 2002, pelo IAC).

A falta de estudos aprofundados sobre as diferenças morfológicas (Jank, 1995), morfológicas e nutritivas entre os materiais genéticos lançados, e sobre o 
impacto que tais diferenças causam na eficiência de utilização de recursos do meio e, em última instância em produtividade, impede que avanços direcionados a esta ou àquela direção ocorram.

\subsubsection{Potencial de produção}

Diversos experimentos utilizando capins do gênero Panicum comprovaram o seu elevado potencial produtivo. Uebele (2002) e Bueno (2003) também relatam produções da ordem de $25 \mathrm{Mg} \mathrm{ha}^{-1} \mathrm{ano}^{-1}$ de MS. Santos et al. (1999) relatam produções médias de 5,5, 8 e $9 \mathrm{Mg} \mathrm{ha}^{-1}$ de MS e 4,5, 6 e $7 \mathrm{Mg} \mathrm{ha}^{-1}$ de MS por pastejo com intervalos de 28, 38 e 48 dias, para os capins mombaça e Tanzânia respectivamente de setembro a maio; Cecato et al. (1996) encontraram produção média de 7 e $2 \mathrm{Mg} \mathrm{ha}^{-1}$ de MS por corte para o capim Mombaça no verão e inverno respectivamente. Rosseto (2000) encontrou acúmulos de forragem variando de 1,2 a $4 \mathrm{Mg} \mathrm{ha}^{-1}$ de $\mathrm{MS}$ em ciclos de pastejo durante o período das chuvas. Teixeira (1998) relatou acúmulo de forragem de $34 \mathrm{Mg} \mathrm{ha}^{-1} \mathrm{ano}^{-1}$ de MS com o capim tobiatã e Tosi (1999) obteve $30 \mathrm{Mg} \mathrm{ha}^{-1} \mathrm{ano}^{-1}$ de MS com o capim Tanzânia. Penati (2002) mediu acúmulo de forragem de 20 a $30 \mathrm{Mg} \mathrm{ha}^{-1} \mathrm{ano}^{-1}$ de MS para o capim Tanzânia com resíduos variando de 1 a $3 \mathrm{Mg} \mathrm{MS} \mathrm{ha}^{-1}$.

\subsubsection{Valor nutritivo}

O valor nutritivo da forragem, quando comparado sob as mesmas condições (i.e. estado físiológico), observa-se que a variabilidade é pequena entre capins e até entre espécies e gêneros de gramíneas forrageiras tropicais, comparativamente às variações entre idades físiológicas (Euclides, 1995). Machado et al. (1998) encontraram teores semelhantes em oito capins, trabalhando com alturas de resíduo de 20 e $40 \mathrm{~cm}$ (FDN 710 a $760 \mathrm{~g} \mathrm{~kg}^{-1}$, FDA 400 a $440 \mathrm{~g} \mathrm{~kg}^{-1}$, PB 10 a $13 \mathrm{~g} \mathrm{~kg}^{-1}$ de digestibilidade in vitro da matéria seca de 56 a 68\%). Bueno (2003), também para o capim Mombaça encontrou 
valores semelhantes com resíduos de 30 e $50 \mathrm{~cm}$. Tosi (1999) encontrou, para o capim Tanzânia, valores de digestibilidade in vitro da matéria seca, PB e FDN de 710, 100 e $700 \mathrm{~g} \mathrm{~kg}^{-1}$; Teixeira (1998) encontrou teores semelhantes para o capim Tobiatã (130 g $\mathrm{kg}^{-1}$ de PB, $650 \mathrm{~g} \mathrm{~kg}^{-1}$ de FDN, $440 \mathrm{~g} \mathrm{~kg}^{-1}$ de FDA e $740 \mathrm{~g} \mathrm{~kg}^{-1}$ de digestibilidade in vitro da matéria seca).

Valor nutritivo foi, em todos os trabalhos, melhor quando a forragem foi colhida mais jovem. Reid et al. (1973) observaram taxas de redução na digestibilidade in vitro da matéria seca de 1 a $4 \mathrm{~g} \mathrm{~kg}^{-1}$ por dia de rebrota.

Moreno (2004) destacou que características com elevada produtividade agronômica, bom valor nutritivo e, conseqüentemente possibilidade de altas taxas de lotação e de desempenho animal satisfatório são bastante interessantes e se enquadram na proposta de exploração intensiva buscando máxima lucratividade e produtividade elevada. Brâncio et al. (2003b) concluíram que, quando pastejada a cada 35 dias, ao longo de todo o ano, a planta apresenta maior valor nutritivo no início do período chuvoso. Algumas dessas variações são inevitáveis e inerentes à planta e ao ambiente em que estão inseridas, porém apenas através do conhecimento das bases teóricas e dos mecanismos que geram tais variações, evitando-se generalizações, é que se pode conviver com a estacionalidade (inevitável), tentar evitar grandes variações (principalmente em qualidade, por se colher a planta em estádios fisiológicos diferentes) e antever as respostas do sistema.

\subsection{Efeitos de ambiente e genética na composição químico-bromatológica de plantas}

A qualidade da forragem é fundamental para um desempenho animal satisfatório em sistemas de produção baseados em pastagens. O menor valor nutritivo, especialmente das gramíneas $\mathrm{C}_{4}$, limita o desempenho inviabilizando o uso planta forrageira em sistemas onde as metas são desempenhos animal elevados.

A parede celular é um importante componente na avaliação da qualidade de forragem, pois sua composição influencia a digestibilidade da planta. Dentre os componentes da parede celular, a lignina, ligada à estrutura dos polissacarídeos celulose 
e hemicelulose, é determinante na qualidade da parede celular (Watson, 1990). Para Buxton \& Fales (1994) a redução na digestibilidade da matéria seca da forragem não é causada simplesmente pelo aumento da proporção de fibra em relação ao conteúdo celular mas também por mudanças qualitativas na fibra.

A parede celular tem sua composição influenciada por vários fatores ambientais e genéticos que refletem em alterações na digestibilidade da planta. $\mathrm{O}$ conhecimento do mecanismo de ação dessas variáveis é importante para o entendimento do processo de desenvolvimento da parede celular e como isto influencia em a qualidade da planta.

Os estudos sobre o efeito do ambiente e da genética sobre a composição e qualidade da parede celular realizados até o momento mostram que estes têm grande influência sobre a digestibilidade da planta e apontam para a necessidade de identificar e conhecer melhor os fatores e mecanismos que são determinantes neste processo.

\subsubsection{Ambiente}

Dentre os fatores de ambiente que influenciam a qualidade da forragem destacam-se a temperatura, a umidade, a radiação solar, os nutrientes minerais, pragas e doenças. Atualmente tem merecido destaque as mudanças climáticas ocorridas no planeta e que projetam para um futuro próximo, elevação da concentração do $\mathrm{CO}_{2}$ atmosférico e alteração nos modelos de precipitação, afetando o crescimento, desenvolvimento e a qualidade das plantas (Sinclair \& Seligman, 1995).

\subsubsection{Temperatura}

Os componentes da parede celular têm sua síntese mediada por reações enzimáticas que normalmente potencializam sua ação com a elevação da temperatura, que dentre todos os fatores do meio ambiente é aquele que maior influência exerce sobre a qualidade das plantas forrageiras. Segundo Buxton \& Fales (1994) existe pouca informação sobre os efeitos diretos da temperatura sobre as reações que levam à 
formação da parede celular das plantas. Vários trabalhos evidenciam que existe uma estreita correlação entre temperatura e concentração de componentes estruturais da célula, sugerindo que existem pontos de controle dependentes da temperatura no processo de partição de fotoassimilados entre a parede celular e conteúdo celular.

A adaptação térmica das plantas é o fator determinante na distribuição das espécies forrageiras pelo globo terrestre. O menor valor nutritivo das espécies forrageiras tropicais é um indicativo da influência negativa da temperatura em latitudes mais baixas (Wilson, 1982; Minson \& McLeod, 1970), limitando a produção animal nessas regiões. Estudos de campo com plantas forrageiras para a avaliação do efeito de temperatura exigem máximo controle do meio, já que muitos efeitos podem ser atribuídos à maturidade e ontogenia da planta (Buxton \& Fales, 1994).

As gramíneas normalmente apresentam maior concentração de parede celular e um acúmulo mais rápido de lignina, quando comparadas às leguminosas, o que acaba determinando um menor efeito da temperatura sobre a digestibilidade das leguminosas. Deste modo, as diferenças de valor nutritivo entre leguminosas tropicais e temperadas são menores que entre gramíneas tropicais e temperadas (Wilson, 1982).

Vários estudos têm mostrado que temperaturas elevadas promovem crescimento mais rápido, principalmente nas espécies tropicais e esses efeitos geralmente estão negativamente associados com a digestibilidade da parede celular, talvez devido ao aumento proporção de lignina constatada nesta condição. Apesar disso, Fales (1986) não observou correlação entre o aumento nas concentrações de lignina e queda na digestibilidade de festuca (Festuca arundinacea Schreb.) e considerou que isto poderia estar associado à presença de ácidos fenólicos, e ligações destes com polissacarídeos da parede celular, e, estas associações podem ser aceleradas pela elevação da temperatura.

Akin et al. (1987) estudaram os efeitos de temperatura sobre a concentração de ácidos fenólicos e a digestibilidade da festuca (Festuca arundinacea Schreb.) e comparando com o trabalho de Fales (1986) verificou que a concentração de ácido pcomárico variou com a temperatura de maneira similar ao FDN, mais do que o ácido ferúlico, sugerindo assim que os diferentes ácidos fenólicos afetam a digestibilidade de 
diferentes maneiras, o que explica o fato de muitas vezes a lignina, por si só, não ser um bom preditor da digestibilidade de plantas forrageiras.

Hendrickson et al. (1997) verificaram que o decréscimo na digestibilidade da parede celular foi o principal responsável pela queda da digestibilidade da matéria seca em gramíneas $\mathrm{C}_{4}$, já que não foram constatadas ao longo da estação de crescimento mudanças nos teores de FDN e lignina. Jung (1989) constatou que mudanças na composição da lignina foram mais significativas para a queda da digestibilidade do que sua concentração.

$\mathrm{O}$ efeito da temperatura é mais pronunciado nas hastes devido às alterações de anatomia e morfologia e da mesma forma esse efeito é mais sentido em tecidos mais velhos (Buxton \& Fales, 1994). Akin et al. (1987) verificaram em tecidos específicos da lâmina foliar diferentes taxas de digestibilidade, com maiores valores para os tecidos considerados digestíveis como no caso do mesófilo, da epiderme e do parênquima da bainha em detrimento dos tecidos parcialmente degradáveis como no caso dos tecidos vasculares e do esclerênquima.

Sinclair \& Seligman (1995) verificaram que o aumento de temperatura causou aumento na relação folha:haste de gramínea $\mathrm{C}_{3}$, devido principalmente, ao desenvolvimento mais rápido das folhas. Estes mesmos autores verificaram que concentrações elevadas de $\mathrm{CO}_{2}$ atmosférico causaram decréscimo na relação folha:haste de gramínea $\mathrm{C}_{3}$, pois a biomassa gerada pelo aumento do $\mathrm{CO}_{2}$ ficou localizada nas hastes. Entretanto, esta queda pode não representar uma diminuição na qualidade da forragem se o crescimento da haste é conseguido através do aumento da proporção de carboidratos não estruturais, de modo que mudanças na relação folha:haste podem ter uma implicação ambígua na qualidade da forragem .

A consistência da resposta qualitativa da forragem às elevadas concentrações de $\mathrm{CO}_{2}$ e temperatura quando consideradas separadamente, tende a desaparecer quando estes dois fatores são combinados. Estes fatores tendem a se anular, mas algumas vezes um ou outro mantêm uma dominância residual sobre determinada característica. Estes efeitos estão mais presentes nas respostas fisiológicas e bioquímicas, levando à conclusão, de que são necessários mais estudos sobre os efeitos do clima sobre 
determinantes da qualidade das forragens como metabolismo de lignina, partição de carboidratos e parede celular (Sinclair \& Seligman, 1995).

\subsubsection{Radiação Solar}

Mudanças na estrutura de uma comunidade de plantas forrageiras influenciam tanto a qualidade como a quantidade de radiação recebida por essas plantas. Por sua vez, variações na qualidade e quantidade de luz absorvida e refletida pelas diferentes partes da planta determinam alterações na morfologia da planta, como é o caso da relação folha:haste. Variações no fotoperíodo têm importante papel na indução do florescimento em muitas espécies forrageiras, o que acaba afetando a qualidade da forragem (Buxton \& Fales, 1994).

O sombreamento é uma condição freqüente para a maioria das plantas forrageiras e isto pode ocorrer de diversas formas como em períodos nublados, no uso de consorciação de espécies com diferentes alturas, ou mesmo no sombreamento de partes da planta mais próximas do solo pelas partes mais próximas do topo. Numa condição de sombreamento a planta mantém ou aumenta a interceptação de luz para sua atividade fotossintética enquanto que o crescimento das raízes é diminuído, ao contrário do défícit hídrico, em que o crescimento das raízes é inalterado. Esta adaptação da planta ao meio é explicada pela sua plasticidade fenotípica que altera a morfologia e possibilita a planta se

adaptar às alterações do ambiente. Vários estudos vêm demonstrando que o sombreamento causa uma queda na concentração de parede celular e concomitante aumento na digestibilidade, embora existam evidências em contrário, o que mostra um certo conflito na literatura sobre o tema (Buxton e Fales, 1994).

\subsubsection{Umidade}

A água é um elemento essencial nas células das plantas, já que todos os processos metabólicos dependem de sua presença. Além disso, uma quantidade 
adequada é requerida para a manutenção da turgescência e difusão. Solos alagados impõem um elevado estresse nas plantas, pois o nível de oxigênio cai rapidamente, levando o sistema radicular a uma condição de anóxia, que tem forte impacto na produção, porém pouca informação existe sobre seus efeitos na qualidade da forragem (Buxton e Fales, 1994). O déficit hídrico é geralmente a maior limitação física na produção de forragem. A turgescência tem um papel crucial expansão da célula, possibilitando a pressão necessária para a extensão da parede celular. Quando a parede celular expande, a turgescência diminui, causando queda do potencial da água dentro da célula. Isto cria uma diferença de potencial entre o exterior e o interior, movendo mais água para o interior da célula (Buxton \& Fales, 1994). A parte aérea das plantas é comparativamente mais afetada pelo déficit hídrico do que as raízes. Esta adaptação existe para preservar a habilidade das raízes para extrair água do solo, ao mesmo tempo em que a perda da água pela transpiração diminui (Buxton \& Fales, 1994).

Akin et al. (1995) avaliando os efeitos da concentração de $\mathrm{CO}_{2}$ e da irrigação sobre a digestibilidade e concentração dos componentes da parede celular do trigo (Triticum aesturim L.) verificaram que o uso de lâminas de água maiores causou decréscimo na digestibilidade, com concomitante aumento nos teores de lignina, principalmente nas folhas mais velhas. $\mathrm{O}$ ambiente enriquecido com $\mathrm{CO}_{2}$ causou aumento em vários dos constituintes aromáticos (ácidos fenólicos) em lâminas com 32 dias de idade. Segundo os autores é comum que estes componentes em folhas jovens sejam perdidos durante a análise de LDA (lignina em detergente ácido) e, portanto não seriam refletidos nos teores de lignina, como foi o caso.

\subsubsection{Nutrientes}

Dentre todos os nutrientes, o $\mathrm{N}$ tem o maior impacto no crescimento da planta, seja pela fixação simbiótica por bactérias em leguminosas ou suprido pela fertilização ou mineralização do N orgânico, no caso das gramíneas (Buxton \& Fales, 1994). O efeito dos fertilizantes nitrogenados sobre a digestibilidade da matéria seca em plantas forrageiras é complexo e variável. Wilson (1982) listou 80 referências sobre o efeito do $\mathrm{N}$ sobre a digestibilidade de gramíneas e indicou que os efeitos encontrados foram 
igualmente distribuídos em positivos, negativos e nulos. O efeito líquido final irá depender do balanço entre os efeitos benéficos e prejudiciais do $\mathrm{N}$ na planta. Os efeitos benéficos são observados ao estimular o crescimento de novos tecidos na planta que tenham alto conteúdo de proteína bruta e baixo conteúdo de parede celular, notadamente lignina. Mas com o crescimento mais rápido, há um aumento da parede celular na composição da planta, bem como o aumento dos teores de lignina na parede celular.

Cox et al. (1993) testaram doses de N sobre os teores de N, FDA, FDN e DIVMS do milho e constataram que houve resposta linear em função da dose aplicada, com houve queda dos teores de fibra e aumento da DIVMS e dos teores de N. Segundo Buxton \& Fales (1994) o aumento da digestibilidade em virtude da fertilização nitrogenada pode associada às baixas concentrações de $\mathrm{N}$ normalmente encontradas em gramíneas $\mathrm{C}_{4}$, que limitam o desenvolvimento microbiano no rúmen. A adubação nitrogenada também pode alterar a relação folha:haste, contribuindo para a elevação da digestibilidade. De acordo com Buxton \& Fales (1994), nutrientes como P e o K têm mostrado pouco efeito sobre a digestibilidade de plantas forrageiras. Em solos com defíciência de $\mathrm{Ca}$, foram observados pequeno aumento na digestibilidade de plantas com a aplicação desse nutriente devido às mudanças ocorridas na planta.

\subsubsection{Genética}

A qualidade da forragem sempre foi relegada ao segundo plano em programas de melhoramento de forragens, pois plantas jovens para a maioria das espécies estudadas possuíam alto valor nutritivo. Além disso, o manejo de pastejo e corte, em diferentes idades, influencia mais a qualidade do que os ganhos obtidos com o melhoramento. No entanto, como plantas com maior maturidade proporcionam melhores ganhos de produtividade e menores custos de produção, o uso de forragens com melhor qualidade em estágios mais avançados de maturidade podem trazer maior retorno econômico. Sendo assim, a busca de plantas com melhor qualidade deve ser uma preocupação de programas de melhoramento. 
A qualidade da forragem está relacionada à sua digestibilidade, e esta é diretamente influenciada pelo teor de fibra da planta. Casler (2001) sugeriu que há correlação alta e negativa entre digestibilidade in vitro da matéria seca (DIVMS) e fibra em detergente neutro (FDN).

Buxton \& Casler (1993) consideraram os principais fatores que influenciam a digestibilidade, todos estes relacionados à presença de fibra da planta, como sendo: a) avanço da maturidade e crescimento; b) mudança na proporção relativa dos tipos de células através de mudança nos tecidos estruturais de suporte; e c) espessamento e alongamento da célula per si.

As mudanças que ocorrem na composição da parede celular são principalmente devido à alteração nos teores de lignina, além de mudanças na composição de outros compostos fenólicos da parede celular. Casler (2001) afirmou que a concentração de lignina e sua composição parecem regular geneticamente a variação da DIVMS das culturas forrageiras. Seleção para baixa lignificação da parede celular pode ser mais efetiva para o aumento da digestibilidade in vitro da matéria seca e dos carboidratos da parede celular do que a seleção para altas DIVMS.

Jung \& Buxton (1994) encontraram baixa correlação entre concentração de lignina e de parede celular. Esta baixa correlação, segundo os autores, torna possíveis desenvolver híbridos de milho para silagem com baixo conteúdo de parede celular e deste modo melhorar o potencial de ingestão dos animais, e também com baixa lignificação, o que aumentaria a digestibilidade da parede celular.

Buxton \& Casler (1993) citam que a seleção para redução de tecidos que limitam a digestibilidade da forragem aumenta a qualidade da forragem. Plantas mutantes por indução natural ou química foram isoladas em milho, sorgo e milheto. Folhas e hastes destas plantas também chamadas de mutante "brown-midrib" (bm, brm) têm concentrações menores de lignina (25-50\%) do que plantas normais, com aumento em sua digestibilidade. Isto sugere a possibilidade de melhorar a qualidade de forragens através da alteração genética do processo de lignificação.

Um processo de melhoramento a ser empregador pode ser a engenharia genética, pois através da tecnologia do DNA recombinante pode-se clonar os genes envolvidos na 
biossíntese de lignina e tentar através da mutação genética reduzir a manifestação destes genes. Casler \& Jung (1999) consideram teoricamente possível criar genótipos com alteração na taxa de formação da ligação lignina-polissacarídeos durante o seu desenvolvimento.

A seleção de plantas visando exclusivamente o aumento na qualidade pode trazer efeitos indesejáveis na seleção de materiais forrageiros. Os componentes da lignina assim como compostos fenólicos têm efeito importante na resistência de plantas a doenças e estresse tais como temperaturas elevadas (Buxton \& Casler, 1993). Buxton \& Casler, 1993, avaliaram o efeito de seleção de capins de alfafa para alto e baixo teor de lignina e observaram que após dois anos de crescimento no campo, 34\% de plantas com baixo teor de lignina sobreviveram contra $64 \%$ das com altos teores de lignina. A seleção para melhoria da qualidade é importante, porém sem esquecer o lado econômico de utilização das plantas quanto à produção de matéria seca e sanidade.

A seleção de forrageiras quanto a digestibilidade pode resultar em plantas que apresentam mudanças na anatomia ou morfologia e não em sua composição. Casler (2001) afirmou que selecionando plantas segundo seu valor nutritivo, as mudanças alcançadas podem não estar associada a modificação na quantidade dos constituintes e no desenvolvimento da parede celular. As mudanças podem se dar pelo aumento da participação de células com maior degradabilidade (parênquima) ou menor degradabilidade (células de esclerênquima). Alterações morfológicas também podem mascarar o resultado, pois quando se seleciona para maior digestibilidade ocorre um aumento de partes da planta com maior digestibilidade, como, por exemplo, um aumento da relação folha:haste. Casler (2001) citou uma maior relação folha:haste para plantas de alfafa com baixos teores de lignina.

Os estudos sobre o efeito do ambiente e da genética sobre a composição e qualidade da parede celular realizados até o momento mostram que estes têm grande influência sobre a digestibilidade da planta e apontam para a necessidade de identificar e conhecer melhor os fatores e mecanismos que são determinantes neste processo. Os teores de carboidratos estruturais e de lignina não são suficientes para explicar a digestibilidade da parede celular, sendo necessário um maior entendimento sobre o 
metabolismo e as interações que envolvem estes componentes, inclusive entre os diversos ácidos fenólicos.

\subsection{Crescimento estacional e morfologia de plantas forrageiras}

A grande maioria dos setores da atividade pecuária é passível de planejamento e entre os principais está a produção de alimento. No caso de planejamento da alimentação baseada em pastagens, a principal dificuldade está na estacionalidade produtiva que as gramíneas forrageiras apresentam. Crescimento muito rápido, num curto período de tempo, embora possa resultar em altas produções de forragem, pode não significar alta produção animal, devido ao longo período de escassez no restante do ano (Pedreira, 1972). Diversos trabalhos mostraram que as produções de forragem das espécies tropicais mais utilizadas na região Centro-Sul do Brasil concentram-se no período quente e chuvoso do ano (de Outubro a Março), correspondendo a cerca de 75 a $90 \%$ da produção total, enquanto no inverno (de Abril a Setembro) a produção é da ordem de 10 a 25\% do total anual (Pedreira, 1972; Ghelfi Filho, 1972; Corsi, 1972; Rolim, 1980; Pedreira \& Mattos, 1981; Müller, 2000). Pedreira \& Mattos (1981), estudando a estacionalidade de 25 capins no Estado de São Paulo, encontraram concentrações da produção no verão (proporção da produção total anual) de $94 \%$ para a espécie mais estacional (Digitaria valida, Stent) e $77 \%$ para a melhor distribuída (Andropogon gayanus Kunth. - var. squamulatus - Gamba e Cynodon spp L.C. Rich - cv. Coastcross 1), o que mostra que há variação considerável nessa característica entre espécies.

Vários são os fatores determinantes da estacionalidade de produção de forragem, dentre os quais temperatura do ar, radiação global incidente, fotoperíodo e umidade do solo são consideradas os principais (Villa Nova et al., 1999). Pedreira (1972) apontou que as curvas de taxa de crescimento acompanhavam as curvas de disponibilidade de chuvas durante o verão para várias espécies em Nova Odessa, SP. Segundo Corsi (1972), todavia a concentração da produção forrageira no verão deve-se à temperatura e ao fotoperíodo favoráveis durante esta época do ano. 
Ghelfi Filho (1972) não encontrou variações significativas na distribuição de produção de forragem no capim elefante (Penninsetum purpureum Schum.) irrigado, comparado à testemunha não irrigada de Abril a Setembro, o que poderia ser explicado pelas baixas temperaturas durante o período, associadas aos dias mais curtos, embora o uso da irrigação no inverno tenha proporcionado acréscimo de 28 a 30\% em relação à produção de inverno sem irrigação. Botrel et al. (1991) relataram taxas de acúmulo de forragem médias mensais para capins de capim elefante cerca de quatro vezes superiores (929 vs. $210 \mathrm{Mg} \mathrm{ha}^{-1}$ ) em pastagens irrigadas em relação às não irrigadas durante 0 inverno, embora Herrera Soto (1981) e Monteiro (1996) tenham registrado baixas respostas à irrigação na época seca, no que diz respeito a incrementos na produção forrageira. Pedreira (1972) relatou pequeno ou nenhum acréscimo na produção de forragem em função da adubação nitrogenada, durante a seca, e não verificou variações no número médio de perfilhos das pastagens durante o inverno. A redução no peso médio dos perfilhos, todavia, foi significativa, sugerindo que essa seja a causa da redução da produção durante o inverno.

Em algumas regiões dos trópicos e subtrópicos, as baixas temperaturas noturnas são apontadas como sendo os principais agentes causadores da estacionalidade de crescimento de plantas forrageiras tropicais. No entanto, um dos principais problemas da interpretação de resultados experimentais em ambientes sob condições controladas pode ser a dificuldade de se separar os efeitos de luz (fotoperíodo e intensidade de luz) e de temperatura no crescimento de plantas (Rolim, 1980). Segundo Corsi (1976), o efeito da temperatura é preponderante, embora a importância relativa de cada fator seja difícil de ser quantificada no campo.

A composição morfológica pode variar com a espécie forrageira ou com o manejo empregado. Gerdes et al. (1998) trabalhando com P. maximum (Jacq.) cv. Tanzânia, B. brizantha cv. Marandu e Setaria sphacelata Stapf cv. Kazungula não encontraram diferença entre maturidades (21, 28 e 35 dias), mas encontraram diferença entre espécies, sendo a porcentagem de lâminas maior em Tanzânia que em Marandu e nesta maior que em Kazungula. Silva (1977), trabalhando com capim buffel (Cenchrus ciliaris L.) em intervalos de corte de 14 dias até a idade de 84 dias, reportou maior taxa 
de acúmulo de folhas pela planta, $40 \mathrm{~kg} \mathrm{ha}^{-1} \mathrm{dia}^{-1}$, em relação às hastes, $21 \mathrm{~kg} \mathrm{ha}^{-1} \mathrm{dia}^{-1}$, até 42 dias de crescimento; a partir desta idade, o acúmulo se inverteu e a planta acumulou maior quantia de haste, $82 \mathrm{~kg} \mathrm{ha}^{-1} \mathrm{dia}^{-1}$ em relação a folhas, $40 \mathrm{~kg} \mathrm{ha}^{-1} \cdot \mathrm{dia}^{-1}$. Brâncio et al. (2003a) trabalharam com três capins de Panicum spp. (Tanzânia, Mombaça e Massai) e encontraram diferentes porcentagens de folha, haste e material morto entre os capins e entre épocas do ano. Os capins apresentaram porcentagem de folhas semelhantes $\left(440 \mathrm{~g} \mathrm{~kg}^{-1}\right)$, mas o Mombaça apresentou mais hastes $\left(191 \mathrm{~g} \mathrm{~kg}^{-1}\right) \mathrm{e}$ menos material morto (355 $\left.\mathrm{g} \mathrm{kg}^{-1}\right)$ que Tanzânia e este, mais hastes $\left(159 \mathrm{~g} \mathrm{~kg}^{-1}\right)$ e menos material morto (408 $\mathrm{g} \mathrm{kg}^{-1}$ ) que o Massai que teve respectivamente, 109 e $449 \mathrm{~g} \mathrm{~kg}^{-1}$, de porcentagens de hastes e folhas. Para os três capins, foram encontrados resultados com maiores quantidades de folhas, de novembro a março, mais hastes de setembro a novembro e maior porcentagem de material morto de junho a setembro.

\subsection{Caracterização física de forragens}

O desempenho animal nem sempre pode ser explicado valor nutritivo da forragem e seu consumo voluntário e somente a caracterização bromatológica de alimentos nem sempre é suficiente para explicar as diferenças entre suas digestibilidades. Alimentos de mesma composição podem proporcionar diferenças no desempenho. Magalhães et al. (2002) encontraram diferenças entre a digestibilidade de várias forrageiras e esta, em alguns casos, não estava correlacionada com maior teor de fibra. Nesse trabalho, o capim Tifton 85 (Cynodon spp) apresentou teores de FDN, FDA, celulose e lignina maiores que de Brachiaria decumbens, mas com digestibilidade ligeiramente superior $\left(557 \mathrm{~g} \mathrm{~kg}^{-1}\right.$ contra $\left.527 \mathrm{~g} \mathrm{~kg}^{-1}\right)$. Esta característica foi atribuída ao menor impedimento físico à ação microbiana.

A caracterização física de forragens pode ser importante na avaliação de alimentos e pode auxiliar na explicação de respostas de desempenho animal, porém é raramente determinada, e suas propriedades não são consideradas na formulação de rações (Giger-Reverdin, 2000). Essas avaliações podem auxiliar na explicação do papel da flora microbiana do rúmen e proporcionar melhor entendimento dos motivos que 
levam a diferentes taxas de degradação de alimentos de composição semelhante, mas com características físicas contrastantes, que podem favorecer maior ou menor acesso à colonização do alimento por bactérias ruminais, afetando sua degradação (GigerReverdin, 2000).

O tempo que a forragem é retida no rúmen afeta o consumo voluntário (Minson \& Wilson, 1994). A correlação entre o consumo e a composição química reflete a resistência da forragem à quebra e diminuição do tamanho de partícula. As características fisicas da forragem podem, assim, ajudar a prever e explicar o consumo voluntário de forragem por ruminantes em pastejo (Minson \& Wilson, 1994), pois plantas que possuem caracterização física correlacionada a um maior tempo de retenção no retículo-rúmen podem ser indicativos de um menor consumo voluntário. Mackinnon et al. (1988) testou as diferenças entre espécies forrageiras selecionadas para alta e baixa resistência ao cisalhamento em folhas de azevém (Lolium perenne L.). A força de cisalhamento pode indicar fragilidade da haste e prover uma razoável diferenciação de materiais quanto à sua quebra durante a mastigação (Iwaasa et al., 1998), assim como pode estar mais bem correlacionada com a quebra da forragem durante a mastigação que a composição química da parede celular (Iwaasa et al., 1997).

Forragens de pior valor nutritivo apresentam maior resistência à redução de tamanho no rúmen, aumentando o enchimento ruminal e diminuindo o consumo pelo animal. Pond et al. (1987) trabalharam avaliando tamanho de partícula no material ruminal presente na parte superior e inferior do compartimento do retículo-rúmen e nas fezes, onde animais tinham acesso a dois tipos de forragem de capim bermuda cv. Coastal (Cynodon spp): uma mais nova (DIVMS $=643 \mathrm{~g} \mathrm{~kg}^{-1}$ ) e outra com maior maturidade (DIVMS $=548 \mathrm{~g} \mathrm{~kg}^{-1}$ ). Foi encontrado maior tamanho de partícula quando os animais pastejavam a forragem de qualidade inferior, porém o tamanho médio encontrado nas fezes foi semelhante nas duas forragens indicando que a redução de tamanho para abandonar o rúmen é necessária mesmo para forragens de maior maturidade. Quando os animais consumiram forragem imatura que continha menores teores de FDN encontrou-se menor enchimento do rúmen, maior consumo, menor tempo de retenção no rúmen e maior taxa de renovação. $\mathrm{O}$ valor nutritivo da forragem é 
determinado em grande parte pela degradação física da fibra e a saída da digesta do rúmen (Akin et al., 1990). A fragmentação de forragens consumidas por ruminantes depende de combinação dos processos de mastigação inicial durante a ingestão, subseqüente mastigação durante a ruminação, detrição pelos movimentos da digesta e digestão microbiana e química (Pond et al., 1987).

Avaliações fỉsicas podem ser usadas para desenvolver modelos que relacionem as características físicas a teores de nutrientes na forragem, tais como PB, FDA, FDN e (DIVMS). Mir et al. (1995) encontraram equações que relacionavam resistência à moagem e valor nutritivo de forragens, com coeficientes de determinação $\left(R^{2}\right)$ variando entre 0,5 a 0,94 no capim-timóteo (Plheum pratense cv. Clímax), 0,4 a 0,96 em capim cevadilha (Bromus inermis cv. Manchar), 0,82 a 0,93 em capim caniço malhado (Phalaris arundinacea $\mathrm{cv}$. Vantage), 0,65 a 0,96 na alfafa (Medicago sativa cv. Beaver) e 0,71 a 0,97 para trevo vermelho (Trifolium pratense cv.Norlac). Esses autores afirmaram que o teor de PB e a DIVMS de $P$. pratense e $B$. inermis podem ser estimados pela resistência à moagem de forragens, usando-se suas respectivas equações. A regressão entre os vários parâmetros nutricionais e a resistência à moagem é melhor quando as forragens são analisadas individualmente e equações incluindo todas as forragens não são possíveis, pois as diferentes plantas apresentam coeficientes de determinação diversos para os parâmetros analisados onde, por exemplo, estes coeficientes para PB $(0,59)$ e DVMS $(0,76)$ são elevados para $P$. pratense e não o são para B. inermis, respectivamente 0,02 e 0,04 (Mir et al., 1995).

\subsection{Composição químico-bromatológica}

A qualidade da dieta obtida pelo animal em pastagem é fundamental para o seu desempenho, pois como citado por Ruffier (1918), "Pode haver gado sem raça, mas por muito boa que seja a raça, si o boi não tem o que comer...".

Fatores relacionados à forragem, como valor nutritivo, afetam o desempenho e a produtividade animal em pastagens. Dentre os fatores inerentes ao animal podem ser incluídos espécie, peso vivo, sexo, tamanho e taxa de bocado, tempo de pastejo (Seman 
et al, 1991). Entre os fatores "da pastagem" pode-se destacar altura do dossel, densidade volumétrica ("bulk density") da forragem e grau de maturidade, assim como fatores inerentes à espécie e ao meio, tais como digestibilidade, concentração de PB e de componentes da parede celular.

O principal fator que afeta o desempenho animal é o consumo voluntário, ou seja, a quantidade de alimento que o animal ingere diariamente quando não há restrição quantitativa ao consumo (Minson \& Wilson 1994). Em estudo com Brachiaria decumbens (Stapf), o ganho médio diário (GMD) foi de $460 \mathrm{~g}$ no período chuvoso, e 235 $\mathrm{g}$ no período seco. Contudo, os animais foram capazes de produzir GMD de $800 \mathrm{~g} \mathrm{dia}^{-1}$ em outubro e novembro quando a produção foi maior e a forragem possuía melhor valor nutritivo (Euclides et al., 1993). Teixeira Neto (1977) reportou que a digestibilidade "in vitro" da forragem de capim colonião (Panicum maximum Jacq.) caiu 0,23 unidades percentuais por dia. Perdas maiores foram registradas com capim buffel (Cenchrus ciliaris L.), quando o tempo da rebrotação variou de 42 a 84 dias com queda média diária da digestibilidade in vitro de 0,47 unidades percentuais por dia para a planta inteira; os valores foram menores para folhas $(0,11$ unidades percentuais por dia) e maiores para haste $(0,62$ unidades percentuais por dia), demonstrando a maior influência das hastes na perda total de digestibilidade da forragem (Silva, 1977).

Em capim-jaraguá (Hyparrenia rufa (Ness) Stapf) cortado nas idades de 28, 56, $84,112,140$ e 168 dias, as maiores digestibilidades e teores de proteína e os menores teores de FDA nos materiais foram obtidos de forragem nova (28 dias), sendo as amostras de lâmina sempre de melhor composição que as hastes em todas as idades. Apesar disso houve queda mais acentuada dos teores de proteína $\left(6 \mathrm{~g} \mathrm{~kg}^{-1} \mathrm{dia}^{-1}\right) \mathrm{e}$ digestibilidade das lâminas $\left(1 \mathrm{~g} \mathrm{~kg}^{-1} \mathrm{dia}^{-1}\right)$ que dos hastes, respectivamente, $4 \mathrm{~g} \mathrm{~kg}^{-1} \mathrm{dia}^{-1}$ e $7 \mathrm{~g} \mathrm{~kg}^{-1} \mathrm{dia}^{-1}$ (Pinheiro, 1975).

Existe correlação negativa entre teores de fibra e lignina e a digestibilidade de lâmina, haste e planta inteira. A queda da digestibilidade in vitro, com o aumento de 1,0 $\mathrm{g} \mathrm{kg}^{-1}$ no teor de fibra e lignina é mais acentuada na lâmina foliar, respectivamente $4,0 \mathrm{~g}$ $\mathrm{kg}^{-1}$ e $2,0 \mathrm{~g} \mathrm{~kg}^{-1}$ que em hastes, respectivamente de $2,8 \mathrm{~g} \mathrm{~kg}^{-1}$ e $0,7 \mathrm{~g} \mathrm{~kg}^{-1}$. O menor efeito do aumento dos teores de lignina e fibra sobre digestibilidade de hastes do que desse 
aumento nas folhas pode ser porque já há alta concentração de tecidos lignificados e com maior presença de parede celular nas hastes (Pinheiro, 1975). A maior concentração de tecido lignificado é encontrada no caule e nervura central, enquanto o limbo concentra a maior parte do tecido epidérmico e vascular não lignificado. Em plantas novas há maior proporção de tecido parenquimático e a proporção de tecidos lignificados aumenta com a maturidade (Brito et al., 1997b).

A forragem pode sofrer alterações qualitativas em função da época do ano e em resposta ao manejo empregado nas pastagens. Ruffier (1918) confeccionou tabela com a composição de diferentes alimentos, a partir de dados de diferentes autores, comparando o valor nutritivo de vários alimentos onde era acentuada a melhor composição bromatológica de plantas novas e não florescidas. Esse autor apontava para a importância do manejo e do momento da colheita da forragem pelo animal, relatando a influência da idade da planta sobre sua digestibilidade e recomendando o pastejo de "plantas com folhas novas, não maduras, pois estas são mais nutritivas". Em capim elefante foi encontrado maior produção de forragem com o aumento do intervalo entre cortes, que variou de 4 a 14 semanas; porém, a produção de proteína por área, porcentagem de proteína na folha e proporção de folhas na massa seca, foi maior no corte de 4 semanas e reduzindo com o aumento do intervalo entre cortes. O maior aumento do teor de fibra foi maior com a idade das hastes que das folhas, respectivamente 0,11 unidades percentuais por dia e 0,04 unidades percentuais por dia (Brito et al., 1962).

Balsalobre (2002) reportou menor valor nutritivo da forragem em amostra de pastejo simulado de capim Tanzânia de julho a setembro, o que foi atribuído à menor renovação de tecidos durante o período de inverno e ao provável acúmulo de perfilhos florescidos desde abril. Naquele experimento, o autor encontrou maior valor nutritivo da forragem, durante o verão, no tratamento de menor resíduo pós-pastejo (pastejo mais intenso - $1000 \mathrm{~kg} \mathrm{MS} \mathrm{ha}^{-1}$ ), assim como foi o tratamento que apresentou menor redução do valor nutritivo entre verão para a primavera. Ventrella et al. (1997) trabalhando com três espécies de Cynodon spp encontraram maior proporção de tecidos mais facilmente digestíveis e melhor composição bromatológica durante o inverno. Flores et al. (1993) 
encontraram maior consumo voluntário de matéria orgânica e menor tempo de retenção ruminal em amostras de forragem cortadas na primavera que aquelas cortadas no verão, para capim elefante cv. Mott e capim Pensacola (Paspalum notatum Flugge). Minson \& McLeod (1970) encontraram elevada correlação entre temperaturas média $(r=-0,76)$, evaporação $(r=-0,64)$ e temperatura e evaporação $(r=-0,83)$ e a digestibilidade da matéria seca e concluíram que a diferença entre a digestibilidade de forrageiras temperadas e tropicais são altamente correlacionadas com diferenças climáticas.

A produtividade das pastagens e o desempenho animal obtido a partir delas são objeto de numerosos estudos. O acúmulo de forragem varia com a espécie forrageira e ambiente a qual está inserida e a manipulação destes fatores pode determinar a produção da planta. A proporção dos componentes morfológicos (folha, haste e material morto) influencia tanto a resposta da planta como a do animal. Uma maior proporção de folhas pode ser indicativo uma forragem de maior valor nutritivo e maior consumo por animais daquela pastagem.

A caracterização da forragem presente na pastagens é importante para se conhecer e estimar resposta do animal. Várias são as maneiras de avaliar a forragem e exame das características físicas tem se mostrado um bom indicativo por se correlacionar tanto o processo físico da digestão (preensão, mastigação, detrição e ruminação) como com o valor nutritivo da forragem.

O valor nutritivo é o principal indicativo para caracterização de forragens, tanto por sua influência no consumo que aumenta com o valor nutritivo, como a resposta do animal a uma maior ingestão de nutrientes. O conhecimento do valor nutritivo e o uso de modelos que estimam o desempenho animal podem ser ferramentas importantes para prever respostas animal em pastagens.

A avaliação de forragens existentes e de lançamentos permite conceber um grande número de informações que auxiliem na seleção e melhoramento de espécies, indicação de espécies e capins adequados e o seu melhor manejo em diferentes ambientes e condições de uso, além de permitir a estimativa dos resultados a serem alcançados em sistemas de produção baseados em pastagens. 
ambientes e condições de uso, além de permitir a estimativa dos resultados a serem alcançados em sistemas de produção baseados em pastagens.

\section{MATERIAL E MÉTODOS}

\subsection{Local do experimento, dados climáticos, delineamento experimental e tratamentos}

O experimento foi realizado em área experimental (Figura 1) pertencente ao Departamento de Zootecnia da ESALQ/USP, em Piracicaba, SP, a $580 \mathrm{~m}$ de altitude, $22^{\circ} 42^{\prime \prime} 30^{\prime \prime} \mathrm{S}$ e $47^{\circ} 30^{\prime} \mathrm{W}$, onde as características médias das normais meteorológicas incluem precipitação $1.247 \mathrm{~mm} / \mathrm{ano}, 20,8^{\circ} \mathrm{C}$ de temperatura (Figura 2), 69\% de umidade relativa do ar. O experimento teve início em 20 de dezembro de 2002 e término em 08 de abril de 2004.

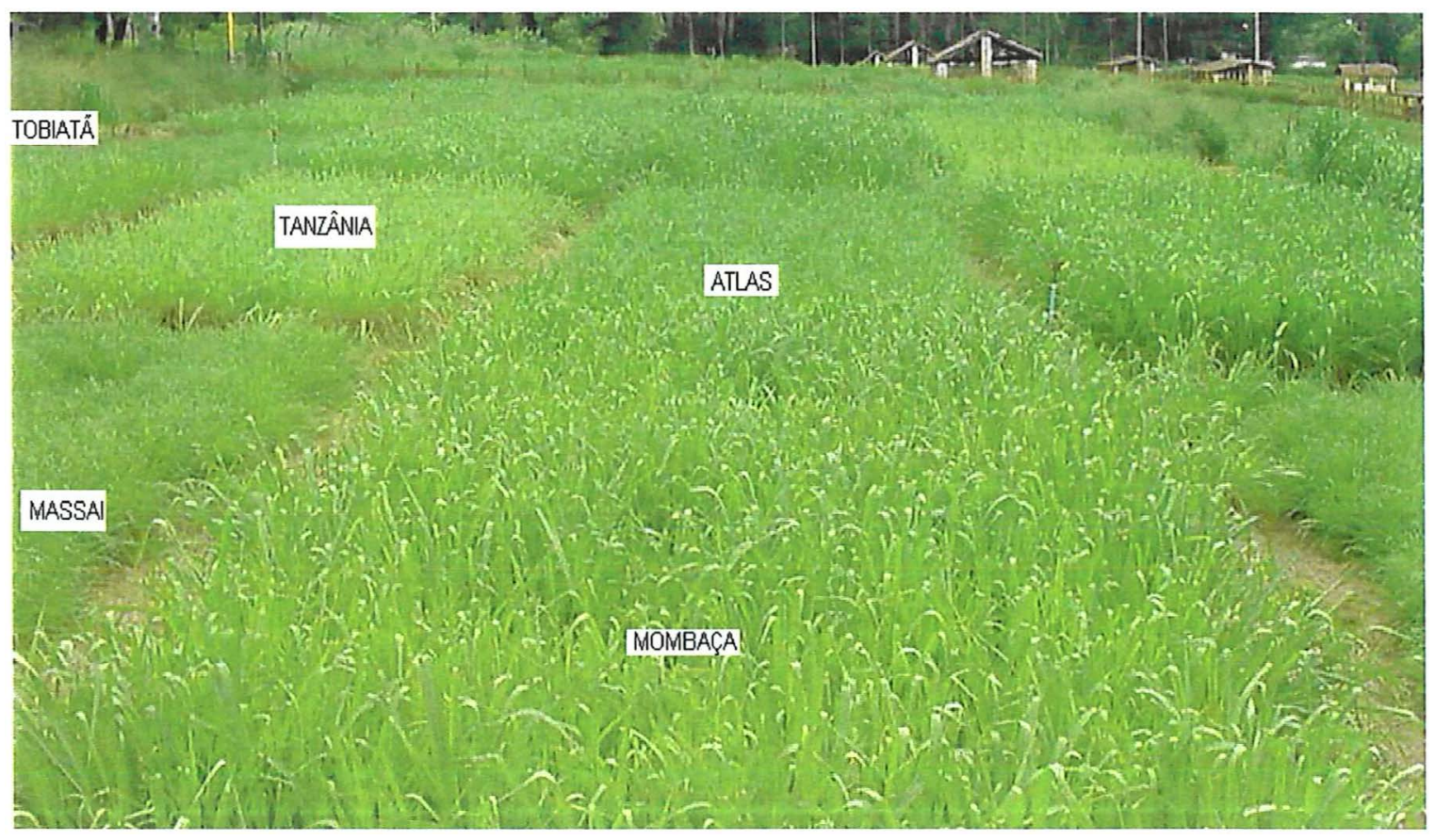

Figura 1 - Área experimental 


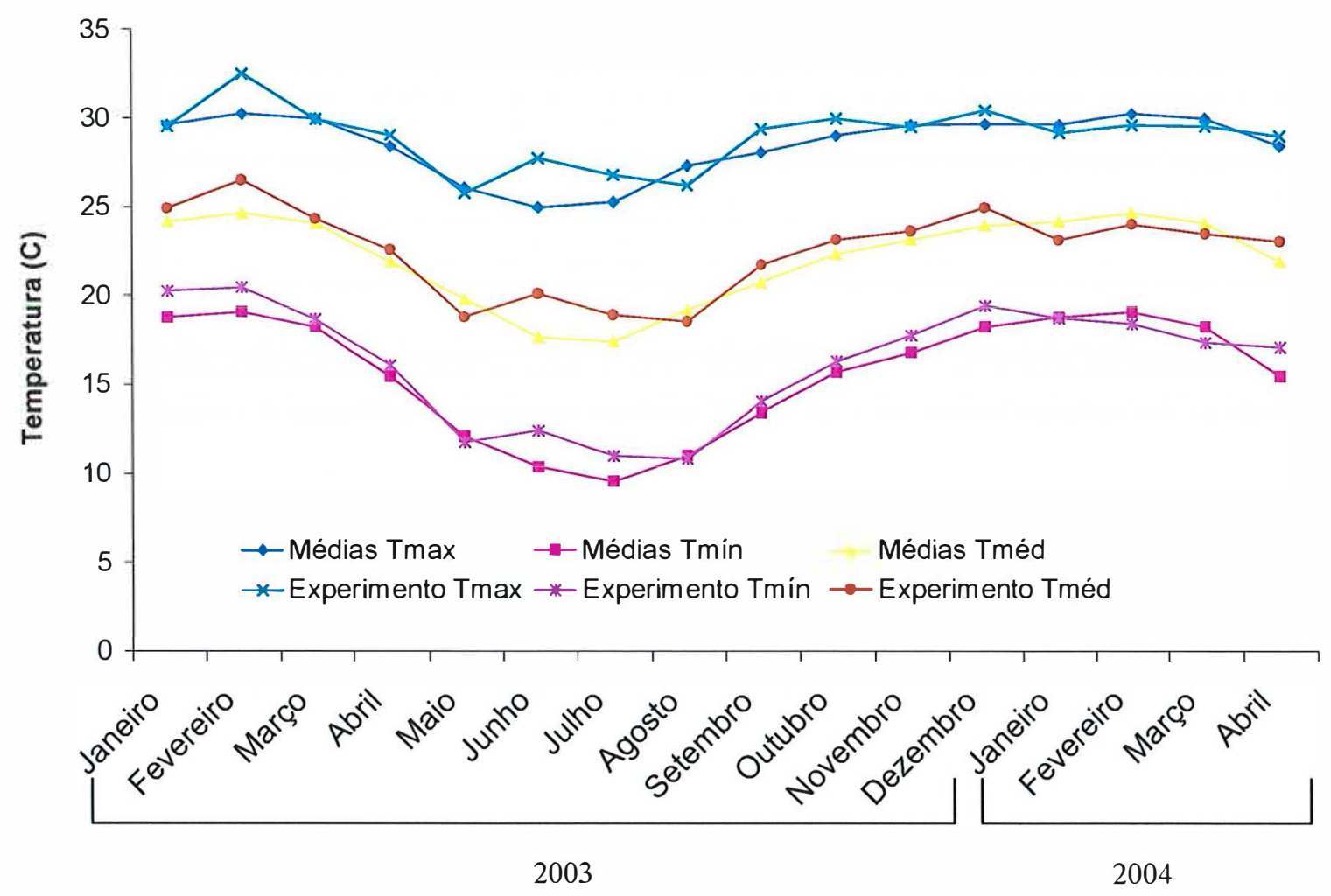

Figura 2 - Médias mensais de temperaturas máximas, médias e mínimas durante todo o período experimental comparadas com dados médios de 1917 a 2003

O solo da área experimental é classificado como Nitossolo Vermelho Eutrófico típico (EMBRAPA, 1999) ou Kandiudalfic Eutrodox (Soil Survey Staff, 1990) e de fertilidade elevada (Tabela 1).

Tabela 1. Valores de fertilidade da área experimental

\begin{tabular}{|c|c|c|c|c|c|c|c|c|c|}
\hline $\begin{array}{c}\mathrm{pH} \\
\mathrm{CaCl}_{2}\end{array}$ & $\begin{array}{l}\text { M.O. } \\
\mathrm{g} / \mathrm{dm}^{3}\end{array}$ & $\begin{array}{c}\mathrm{P} \\
\mathrm{mg} / \mathrm{dm}^{3}\end{array}$ & $\mathrm{~K}$ & $\mathrm{Ca}$ & $\begin{array}{r}\mathrm{Mg} \\
\mathrm{mm}\end{array}$ & $\begin{array}{l}\mathrm{H}+\mathrm{Al} \\
/ \mathrm{dm}^{3}\end{array}$ & SB & $\mathrm{T}$ & $\begin{array}{c}\% \\
\%\end{array}$ \\
\hline 5,5 & 32 & 70 & 2,2 & 56 & 25 & 22 & 82,6 & 105,1 & 79 \\
\hline
\end{tabular}

Durante dois verões e um inverno (dezembro de 2002 a abril de 2004) foram estudados quatro capins de Panicum maximum: Atlas, Massai, Mombaça, Tanzânia, e Tobiatã e um híbrido natural de $P$. maximum e $P$. virgatum, o capim Massai, em um 
delineamento experimental de blocos completos casualisados, com cinco tratamentos correspondendo aos cinco capins e quatro repetições, totalizando 20 unidades experimentais (parcelas), cada uma medindo $10 \times 4 \mathrm{~m}$, e separadas por corredores de aproximadamente $0,8 \mathrm{~m}$ de largura (Figura 1).

A escolha de freqüência de corte foi tomada com base em algumas características inerentes aos cultivares (Moreno, 2004). O cultivar Massai tem ciclo de florescimento precoce (Jank, comunicação pessoal) e floresce o ano todo (Savidan et al., 1990) e de forma similar, o cultivar Atlas possui ciclo de florescimento médio (Usberti Filho, comunicação pessoal) devendo ambos serem manejados com cortes mais freqüentes. $\mathrm{O}$ cultivar Tanzânia tem como características abundância de folhas e menor porte (Jank, 1995 ) permitindo cortes a uma freqüência menor. A maioria dos trabalhos descritos na literatura reportam 35 dias de intervalo de desfolhas para o capim Tanzânia (Tosi, 1999; Rosseto, 2000 e Penati, 2002). O cultivar Mombaça, com maior porte e maior crescimento de hastes (Jank, 1995) apresenta vantagens se desfolhado com maior freqüência. Para o cultivar Tobiatã os dados são mais escassos sendo que Teixeira (1998) utilizou intervalo entre desfolhas de 35 dias.

Com o intuito de simular situação de produção intensiva de forragem sob desfolha intermitente, foram feitas adubações com $450 \mathrm{~kg} \mathrm{ha}^{-1} \mathrm{ano}^{-1}$ de $\mathrm{N}$ e $\mathrm{K}_{2} \mathrm{O}(2.250$ $\mathrm{kg}$ da fórmula 20-00-20), aplicados de forma parcelada, onde o total de adubo a ser aplicado em cobertura foi dividido pelo número de cortes efetuados no ano e realizadas aplicações manuais imediatamente após cada corte, parcelando equanimente o total anual.

Para que a água não fosse fator limitante à produção (um dos fatores causadores da estacionalidade de produção), a área foi irrigada uma ou duas vezes por semana, durante todo o período experimental, sendo o manejo da irrigação baseado no monitoramento das condições hídricas do solo, com a utilização de tensiômetros instalados a $20 \mathrm{~cm}$ de profundidade. Antes que a tensão se elevasse a valores próximos a $-30 \mathrm{~cm} \mathrm{Hg}$, que equivale a $83 \%$ da capacidade de campo, a irrigação era ligada por 4 horas. Este turno de rega equivalia à precipitação de $30 \mathrm{~mm}$. O procedimento se repetiu 
após as adubações com a finalidade de reduzir as perdas de nitrogênio por volatilização, melhorando a eficiência da adubação.

Os cortes e coleta de amostras foram feitos com aparador de cerca viva, deixando-se resíduo de aproximadamente $0,35 \mathrm{~m}$ para todos os capins, com exceção do Massai que foi cortado a $0,15 \mathrm{~m}$ do solo, pois apresenta porte mais baixo que o dos outros materiais estudados, procurando fazer com que a intensidade de desfolha fosse equivalente entre capins (Figura 3).

Foram efetuados dois tipos de cortes para obtenção das amostras: cortes para obtenção de produção e cortes para obtenção de amostras de acompanhamento da rebrotação.

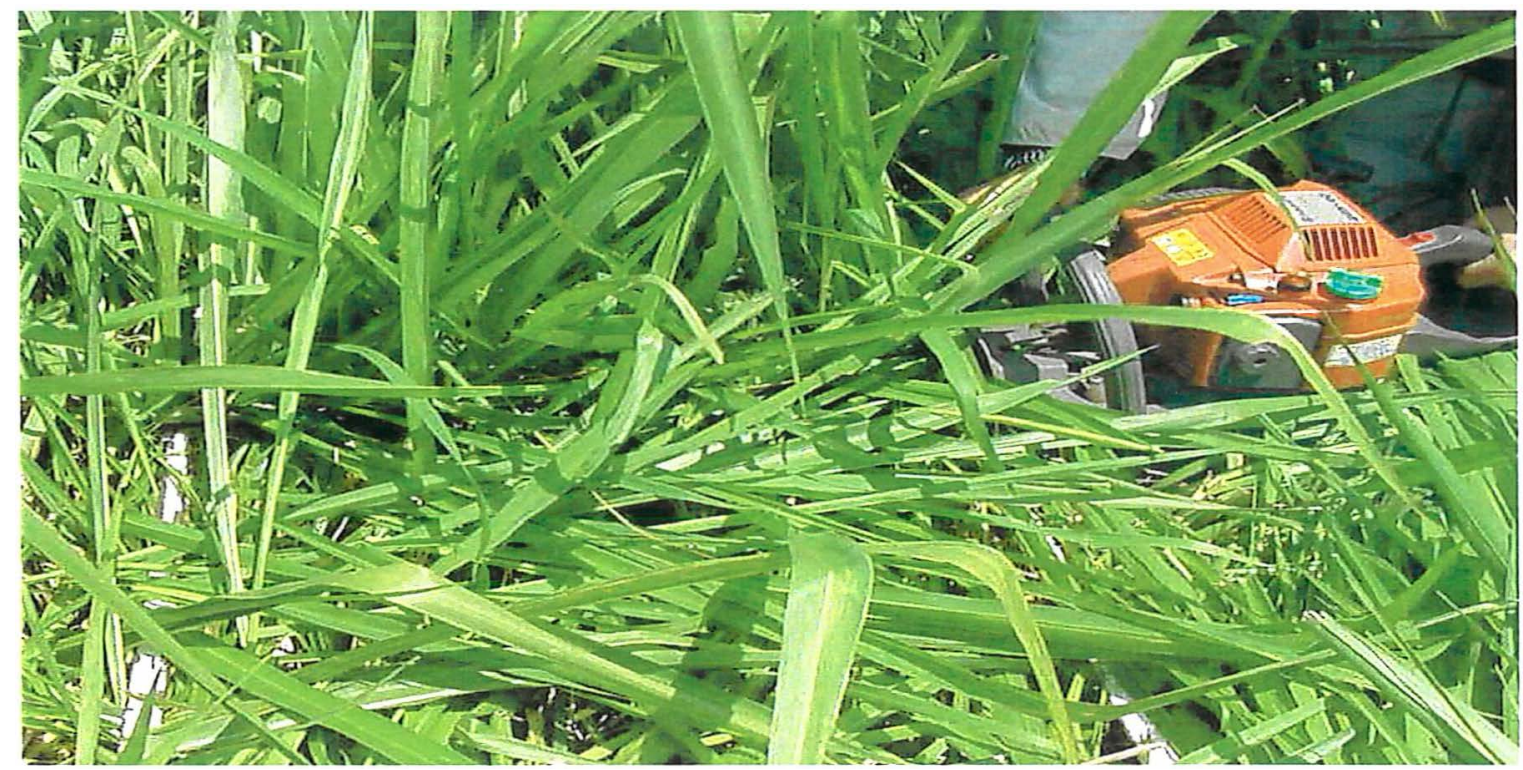

Figura 3 - Amostragem da massa de forragem

\subsection{Amostras de produção}

Os cortes foram feitos a cada quatro (verão) ou sete semanas (inverno) nas parcelas de Atlas, Massai e Mombaça e de cinco (verão) ou nove semanas (inverno) nas de Tanzânia e Tobiatã e a cada data de corte foram feitas amostragens para quantificação da massa de forragem (MF) acumulada acima do resíduo (cortes de produção) (Tabela 
2). A massa de forragem era obtida como a média da massa amostradas dentro de três quadrados de $1 \mathrm{~m}^{2}$. A forragem fresca proveniente de cada quadrado foi pesada e subamostrada em aproximadamente $600 \mathrm{~g}$ e as sub-amostras foram acondicionadas em sacos de pano, colocadas em estufa de circulação forçada a $65^{\circ} \mathrm{C}$ até peso constante e novamente pesadas para a determinação do teor de matéria seca e, conseqüentemente, massa seca de forragem da amostra.

Tabela 2. Cronograma de corte da forragem nas unidades experimentais

\begin{tabular}{|c|c|c|c|c|}
\hline Corte & $\begin{array}{l}\text { Tobiatã / } \\
\text { Tanzânia }\end{array}$ & Estação & $\begin{array}{c}\text { Atlas / Massai / } \\
\text { Mombaça }\end{array}$ & Estação \\
\hline 0 & 20/dez/02 & verão & $20 / \mathrm{dez} / 02$ & verão \\
\hline 1 & 24/jan/03 & verão & 17/jan/03 & verão \\
\hline 2 & $4 / \mathrm{mar} / 03$ & verão & 18/fev/03 & verão \\
\hline 3 & 8/abr/03 & verão & $18 / \mathrm{mar} / 03$ & verão \\
\hline 4 & 10/jun/03 & inverno & 15/abr/03 & verão \\
\hline 5 & 12/ago/03 & inverno & 3/jun/03 & inverno \\
\hline 6 & 14/out/03 & inverno & 22/jul/03 & inverno \\
\hline 7 & 18/nov/03 & verão & $9 /$ set/03 & inverno \\
\hline 8 & 23/dez/03 & verão & 7/out/03 & verão \\
\hline 9 & 27/jan/04 & verão & 4/nov/03 & verão \\
\hline 10 & $2 / \mathrm{mar} / 04$ & verão & $2 / \mathrm{dez} / 03$ & verão \\
\hline 11 & 6/abr/04 & verão & 30/dez/03 & verão \\
\hline 12 & - & - & 27/jan/04 & verão \\
\hline 13 & - & - & $24 / \mathrm{fev} / 04$ & verão \\
\hline 14 & - & - & $23 / \mathrm{mar} / 04$ & verão \\
\hline
\end{tabular}




\subsection{Amostras de acompanhamento da rebrotação}

Durante o período experimental foram acompanhadas, semanal (verão) ou bissemanalmente (inverno), três ciclos de crescimento (três rebrotações): um no primeiro verão, um no inverno e outro no segundo verão agrostológico (Tabela 3). Estabeleceu-se como 'verão' o período de 21 de setembro a 22 de março, que corresponde ao período de melhores condições para o crescimento de forragem (primavera e verão) e 'inverno' o período de 23 de março a 20 de setembro. Durante estes três ciclos a partir do $7^{\circ}$ dia de rebrotação. Nessas ocasiões foram cortadas duas amostras de forragem por parcela (cortes de acompanhamento), colocando-se dois quadrados de $0,5 \mathrm{~m}^{2}$ na parcela e, em cada quadrado cortava-se a forragem contida dentro do quadrado acima da altura de corte. Em seguida, as amostras colhidas eram congeladas para posterior separação em quatro sub-amostras com seus componentes morfológicos (planta toda, folha, haste e material morto) (Figura 4). Para as sub-amostras de folhas foram considerada apenas a lâmina foliar e para material morto consideraram-se folhas e hastes senescidas e mortas. Após a separação, o material foi colocado em estufa de circulação forçada a $65^{\circ} \mathrm{C}$ até peso constante. 
Tabela 3. Cronograma de amostragem das rebrotações acompanhadas

\begin{tabular}{lccc}
\hline Estação & Dia & Tanzânia/Tobiatã & Atlas/Massai/Mombaça \\
\hline Verão 1 & 0 & $24 / \mathrm{jan} / 03$ & $17 / \mathrm{jan} / 03$ \\
& 7 & $31 / \mathrm{jan} / 03$ & $24 / \mathrm{jan} / 03$ \\
& 14 & $7 / \mathrm{fev} / 03$ & $31 / \mathrm{jan} / 03$ \\
& 21 & $14 / \mathrm{fev} / 03$ & $7 / \mathrm{fev} / 03$ \\
& 28 & $21 / \mathrm{fev} / 03$ & $14 / \mathrm{fev} / 03$ \\
Inverno & 35 & $28 / \mathrm{fev} / 03$ & - \\
& 0 & $10 / \mathrm{jun} / 03$ & $3 / \mathrm{jun} / 03$ \\
& 7 & $17 / \mathrm{jun} / 03$ & $10 / \mathrm{jun} / 03$ \\
& 21 & $1 / \mathrm{jul} / 03$ & $24 / \mathrm{jun} / 03$ \\
& 35 & $15 / \mathrm{jul} / 03$ & $8 / \mathrm{jul} / 03$ \\
& 49 & $29 / \mathrm{jul} / 03$ & $22 / \mathrm{jul} / 03$ \\
& 63 & $12 / \mathrm{ago} / 03$ & - \\
Verão 2 & 0 & $23 / \mathrm{dez} / 03$ & $30 / \mathrm{dez} / 03$ \\
& 7 & $30 / \mathrm{dez} / 03$ & $6 / \mathrm{jan} / 04$ \\
& 14 & $6 / \mathrm{jan} / 04$ & $13 / \mathrm{jan} / 04$ \\
& 21 & $13 / \mathrm{jan} / 04$ & $20 / \mathrm{jan} / 04$ \\
& 28 & $20 / \mathrm{jan} / 04$ & $27 / \mathrm{jan} / 04$ \\
& 35 & $27 / \mathrm{jan} / 04$ & \\
\hline
\end{tabular}




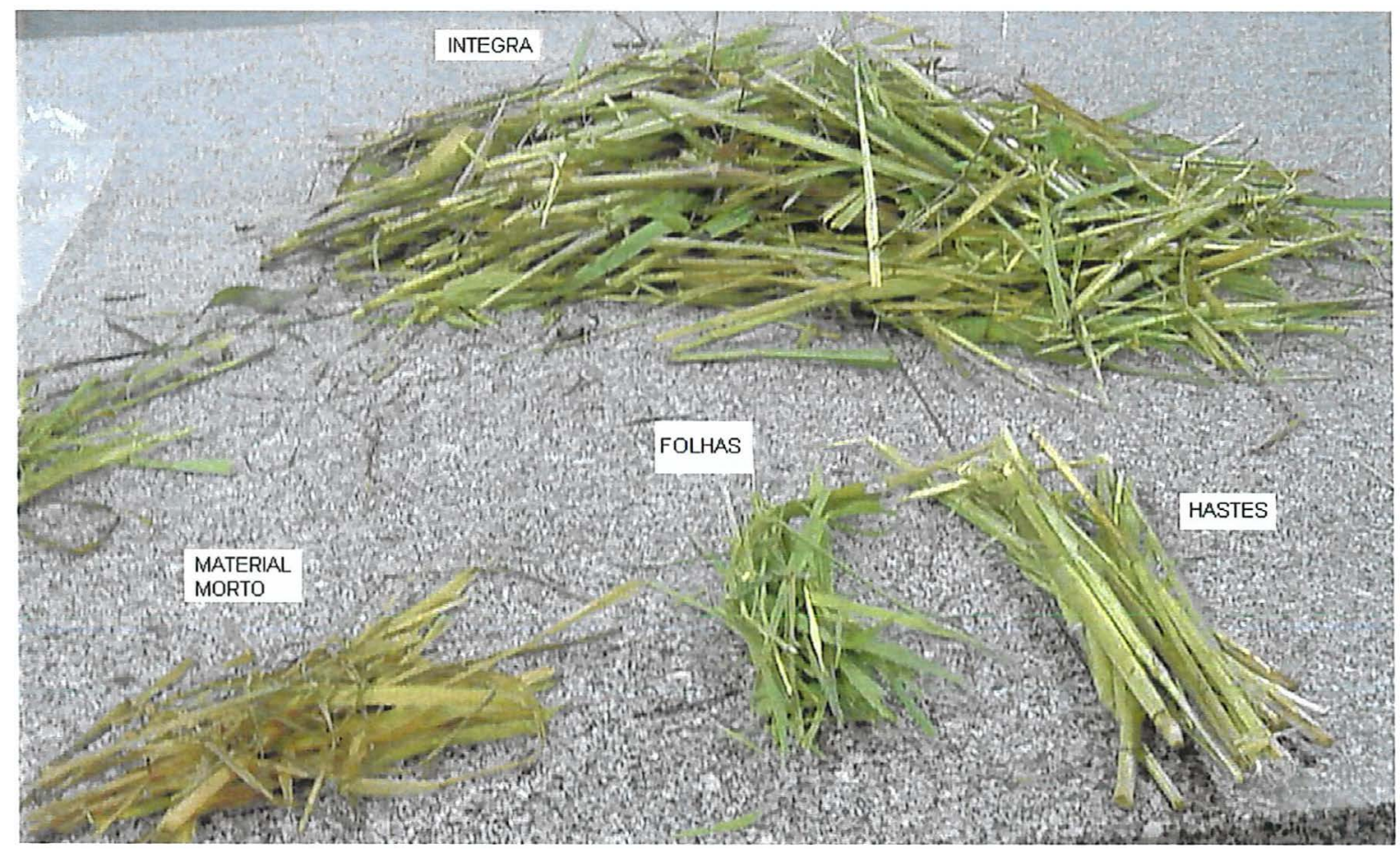

Figura 4 - Amostra separada

\subsection{Caracterizações físicas de forragem}

\subsubsection{Densidade da forragem fresca}

As amostras dos cortes de acompanhamento da rebrotação foram utilizadas nesta determinação, que consistiu numa avaliação da planta antes da secagem, com sua umidade natural e separada em quatro sub-amostras: íntegra (uma sub-amostra não separada), folha, haste e material morto. Essas sub-amostras tinham sua massa e volume determinados. A massa era determinada em balança digital, onde se procurou padronização em aproximadamente $100 \mathrm{~g}$ e o volume foi determinado em um recipiente graduado (volumímetro) (Figura 5). Era colocada uma certa quantia de água, aproximadamente $1 \mathrm{~L}$, no volumímetro, medido este volume e então, a sub-amostra pesada era colocada no recipiente e embebida totalmente na água, e o volume do recipiente era novamente medido. A diferença entre o volume antes e depois de se 
mergulhar a amostra foi considerado o volume da amostra. A densidade foi calculada dividindo-se a massa pelo volume obtido.

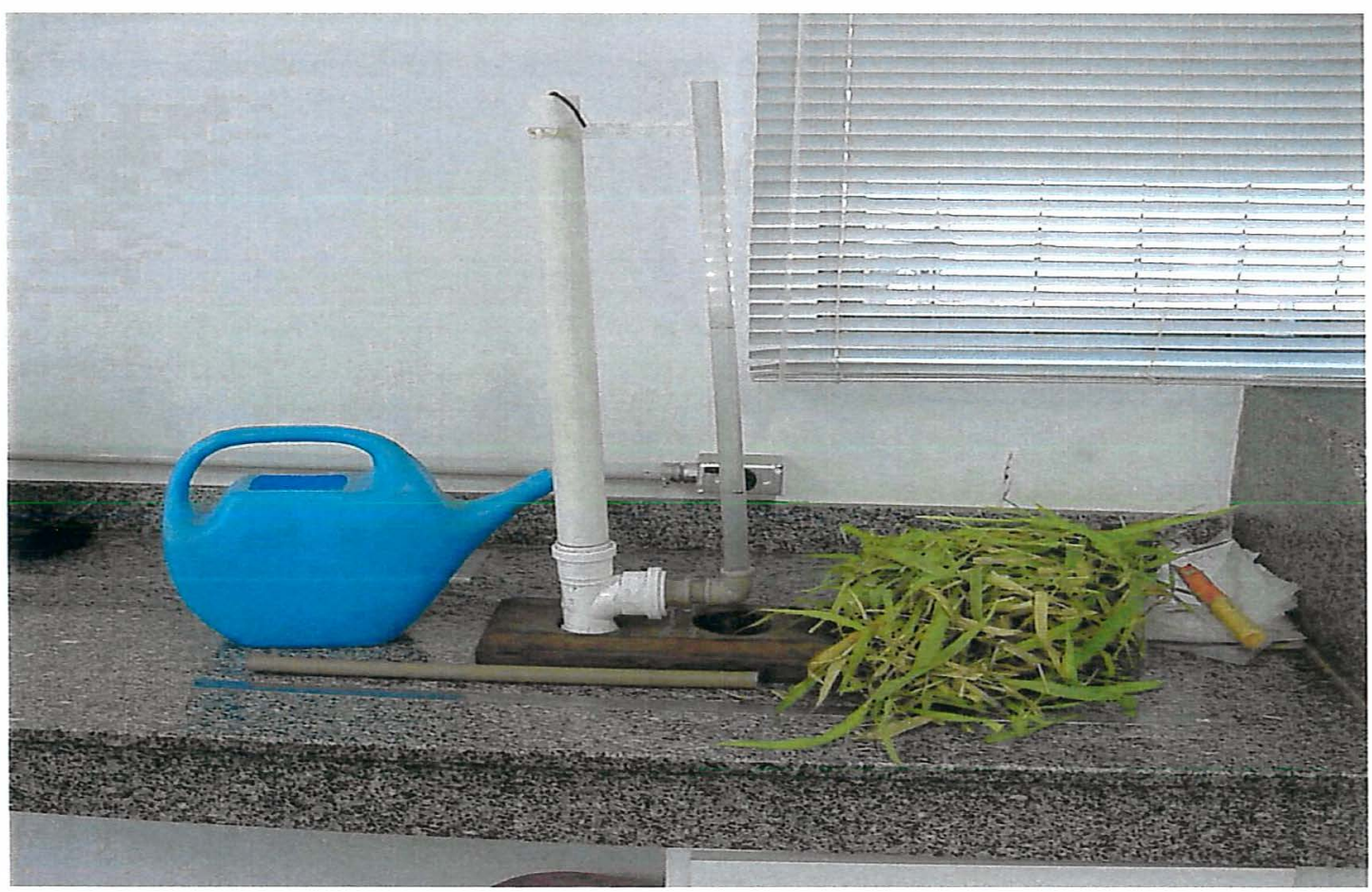

Figura 5 - Volumímetro usado para medir o volume de forragem

\subsubsection{Resistência ao cisalhamento}

Com as amostra frescas provenientes do corte de crescimento do segundo verão, onde foram separadas sub-amostras de hastes e folhas de cada amostra obtida. Essas subamostras continham cinco folhas e cinco hastes representativas da amostra colhida. Cada folha e haste da sub-amostra era então marcada com tinta plástica, pesada, medida o seu comprimento, espessura (folhas) e diâmetro (hastes), acondicionada em saco plástico e armazenadas a $-18^{\circ} \mathrm{C}$. Estas amostras eram então levadas à sala do texturômetro, um aparelho modelo TP 2 - Texture Test System (Food Technology Corporation - FTC, Reston, Virginia, USA) para avaliação. O procedimento, adaptado de Hughes et al. (1998), se repetiu para cada folha e haste em dois locais do material, a 1/3 e 2/3 de seu comprimento. 


\subsubsection{Resistência à moagem}

As amostras secas, tanto dos cortes de produção como acompanhamento da rebrotação, foram processadas em moinho tipo Wiley com peneira de abertura 5,0 mm; após esta moagem inicial, $20 \mathrm{~g}$ deste material moído, que passou pela abertura da peneira 5,0 $\mathrm{mm}$, foi moído novamente com peneira de abertura $1 \mathrm{~mm}$ por um tempo fixo de 25 segundos. O material que passou na peneira de abertura 1,0 $\mathrm{mm}$ foi pesado e o restante do material, que não passou pela peneira, foi considerado resistente à moagem. Os materiais com maior resíduo não moído em relação ao total da amostra foram considerados mais resistentes à moagem (Hughes et al., 1998).

\subsubsection{Densidade da forragem moída}

A densidade da forragem moída foi medida conforme o método adaptado de Giger-Riverdin (2000). Cerca de 25 g de amostra já moída foram colocadas em recipiente de $100 \mathrm{~mL}$ graduado (cilindro com tampa) (Figura 6), suficiente para atingir o volume de $50 \mathrm{~mL}$ e efetuaram-se batidas leves sobre o balcão com o recipiente por 15 segundos. Em seguida, adiciona-se mais material da mesma amostra até o volume de 100 mL, então efetuaram-se batidas leves novamente por 10 segundos. Completou-se o volume com o mesmo material da amostra até $100 \mathrm{~mL}$ e efetua-se batidas leves por 5 segundos, medindo-se então o volume final ocupado pelo material dentro do cilindro e seu peso. A densidade foi calculada dividindo-se o peso da amostra colocada no cilindro pelo volume final ocupado pela amostra (Giger-Riverdin, 2000). Esta avaliação foi realizada sempre pela mesma pessoa. 


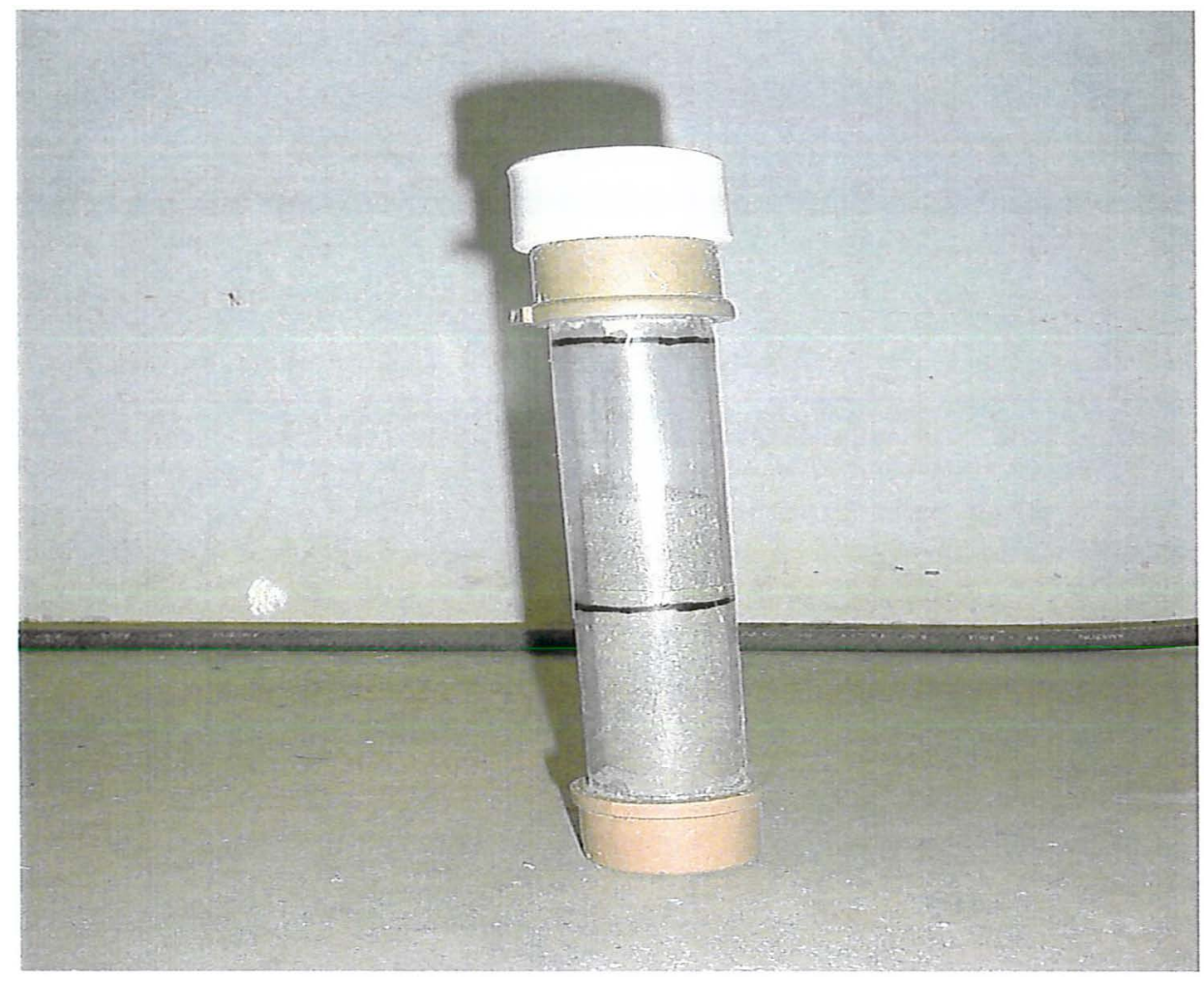

Figura 6 - Recipiente utilizada na avaliação da densidade da forragems seca e moída

\subsubsection{Tamanho médio de partícula}

O tamanho médio de partícula foi determinado usando método adaptado daquele descrito por Giger-Riverdin (2000), onde, após a moagem das amostras de forragem em peneira de abertura de $1,0 \mathrm{~mm}$, uma amostra $50 \mathrm{~g}$ foi colocada por 15 minutos em agitador com jogo de seis peneiras com malhas de $0,420,0,297,0,250,0,180,0,105$ e $0,053 \mathrm{~mm}$ (Figura 7). O material retido em cada peneira foi pesado em balança eletrônica. O tamanho médio de partícula retida em cada peneira foi considerado como sendo a média entre os tamanhos das peneiras que a partícula ficou retida e a de tamanho imediatamente superior. O tamanho médio de partícula de cada amostra foi determinado a partir da média ponderada do tamanho de partícula retido em cada peneira, calculado pela somatória da multiplicação da massa de amostra retida em cada peneira por seu tamanho de partícula e dividido pela massa total da amostra. 


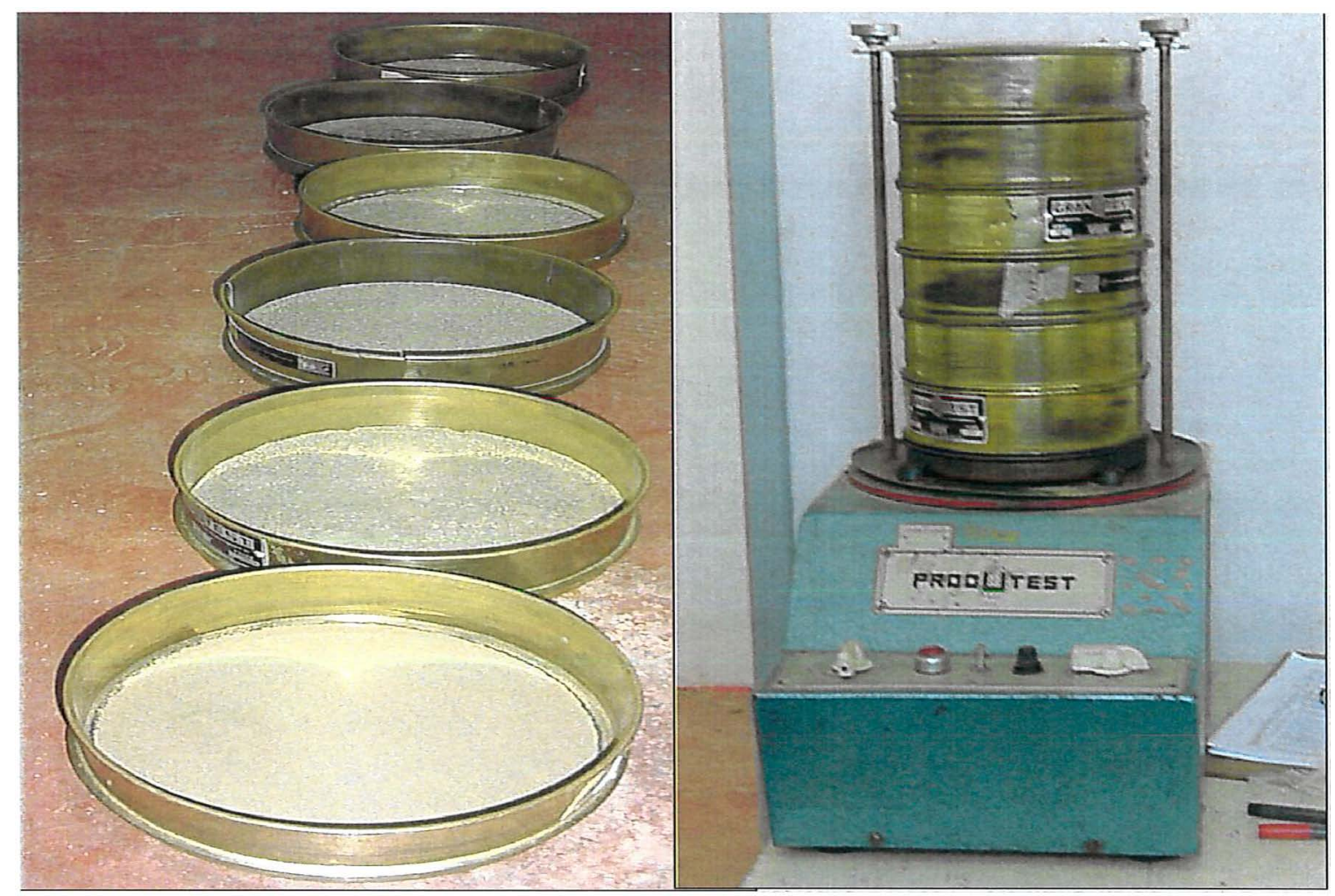

Figura 7 - Peneiras e agitador usado na separação de partículas por tamanho

\subsection{Valor nutritivo}

O valor nutritivo da forragem foi avaliado através da determinação dos teores de PB, FDN, FDA, LIG, HEM, além da DIVMO, DIVMS, DIVFDN e DIVFDA.

As amostras foram analisadas utilizando-se o método de espectroscopia de refletância infravermelho proximal (NIRS) (Jung et al., 1998, Berzaghi et al, 1997 e Cozzolino et al., 2001). Após secas e pesadas, as amostras foram moídas em moinho tipo Wiley com peneira de abertura de $1,0 \mathrm{~mm}$ e submetidas a leituras de infravermelho proximal em aparelho NIRS (Near Infrared Reflectance Spectrometer) para a geração de suas curvas espectrais. O aparelho utilizado foi o monocromato NIRS 5.000 (NIR Systems, Silver Springs, MD, USA) que trabalha lendo comprimentos de onda entre 700 e $2.100 \mathrm{~nm}$, que são convertidos em curvas de $\log (1 / \mathrm{R})$ em intervalos de $2 \mathrm{~nm}$ e armazenadas em seu banco de dados. Após a leitura de todas as amostras, o software integrante do sistema NIRS foi empregado para selecionar $30 \%$ das amostras para 
análise convencional cujos resultados foram inseridos no software integrante do sistema NIRS, para que este realizasse as estimativas dos parâmetros bromatológicos de interesse, utilizando a "biblioteca" de dados do Laboratório de Bromatologia da ESALQ - USP.

\subsection{Análises estatísticas}

Os dados de produção, componentes morfológicos, caracterização física e químico-bromatológica foram submetidos à análise de variância utilizando-se software

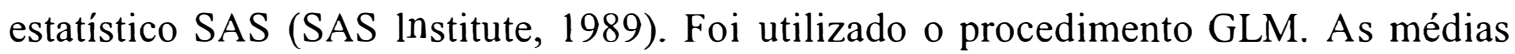
foram comparadas pelo teste de Tukey usando-se o comamdo 'PDIFF' do 'LSMEANS' adotando-se o nível de significância de $5 \%$.

Foram realizadas análises de correlação entre a variável resistência ao cisalhamento e variáveis de valor nutritivo por meio do procedimento estatístico CORR, do software estatístico SAS (SAS Institute, 1989).

Foram realizadas análises de regressão entre proporção de folhas e hastes, variáveis de valor nutritivo e parâmetros cronológicos (dias) e climáticos (graus dias e unidade fototérmica) por meio do procedimento estatístico REG, do software estatístico SAS (SAS Institute, 1989). 


\section{RESULTADOS E DISCUSSÃO}

\subsection{Acúmulo de forragem e composição morfológica de capins de Panicum spp.}

O maior acúmulo de forragem durante o período experimental foi o do capim Massai (Tabela 4), seguido pelos capins Tobiatã, Tanzânia e Mombaça. O capim Atlas foi o que produziu menos forragem em todo o período experimental. $\mathrm{O}$ acúmulo total de forragem obtido durante um ano (18 de março de 2003 a 25 de março de 2004 para os capins Atlas, Massai e Mombaça e 08 de abril de 2003 a 08 de abril de 2004 para os cultivares Tanzânia e Tobiatã) foi inferior aos conseguidos por Santos et al. (1999). Estes autores, em experimento de pastejo, obtiveram acúmulo anual de forragem de $41 \mathrm{e}$ $33 \mathrm{Mg}$ ha. $^{-1}$ ano, respectivamente para Tanzânia e Mombaça. A diferença obtida nos experimentos pode ser creditada em parte às maiores quantidades de nitrogênio (70 a $100 \mathrm{~kg} \mathrm{ha}^{-1}$ por pastejo) aplicadas no experimento de Santos et al. (1999) e nesta pesquisa $\left(50 \mathrm{~kg} \mathrm{ha}^{-1}\right.$ por corte). Os intervalos entre cortes também foram diferentes nos dois trabalhos e podem ter influenciado a produção total obtida. 
Tabela 4. Acúmulo de forragem dentro de cada 'estação' de acompanhamento da rebrotação

\begin{tabular}{cccc}
\hline Capim & Acúmulo total & Acúmulo 'verão' & Acúmulo 'inverno' \\
\cline { 2 - 4 } Atlas & $12,0(1,69) \mathrm{c}$ & $8.6(1,22) \mathrm{c}$ & $3,3(0,52) \mathrm{b}$ \\
Massai & $29,0(1,69) \mathrm{a}$ & $20.4(1,22) \mathrm{a}$ & $8.6(0,52) \mathrm{a}$ \\
Mombaça & $19,7(1,69) \mathrm{b}$ & $15.5(1,22) \mathrm{ab}$ & $4,1(0,52) \mathrm{b}$ \\
Tanzânia & $20,5(1,85) \mathrm{b}$ & $13.6(1,33) \mathrm{bc}$ & $7,0(0,56) \mathrm{a}$ \\
Tobiatã & $21,0(1,69) \mathrm{b}$ & $14.3(1,22) \mathrm{b}$ & $6,8(0,52) \mathrm{a}$ \\
Média & $\mathbf{2 0 , 0}$ & $\mathbf{1 5 , 9}$ & $\mathbf{4 , 6}$ \\
CV (\%) & $\mathbf{3 1 , 7}$ & $\mathbf{2 9 , 8}$ & $\mathbf{4 5 , 3}$ \\
\hline
\end{tabular}

Médias na mesma coluna seguidas da mesma letra não diferem entre si (Tukey, $\mathrm{P}<0,05)$.Valores entre parênteses correspondem ao erro padrão da média

Singh et al. (1995) testaram seis genótipos de Panicum maximum (Jacq.), classificados de acordo com a produtividade de matéria seca em mais produtivos (PGG1, PGG-4 e PGG-8) e menos produtivos (PGG-5, PGG-6 e PGG-7), e obtiveram produções semelhantes às obtidas neste experimento. A produção média obtida naquele experimento foi de $11,2 \mathrm{Mg} \mathrm{ha}^{-1}$ (corte a cada 20 dias), 16,7 $\mathrm{Mg} \mathrm{ha}^{-1}$ (corte a cada 30 dias) e 23,2 $\mathrm{Mg} \mathrm{ha}^{-1}$ (corte a cada 40 dias), tendo ficado a média de produção anual dos genótipos mais produtivos em $19 \mathrm{Mg} \mathrm{ha}^{-1}$ e os menos produtivos em $15 \mathrm{Mg} \mathrm{ha}^{-1}$. Botrel et al. (1999) testou vários capins e entre eles três de Panicum maximum (Jacq), Tobiatã, Green Panic e Makueni, onde se mediu a produção e distribuição estacional de forragem e obtiveram produção de $16 \mathrm{Mg} \mathrm{ha}^{-1}$ para Tobiatã e $7 \mathrm{Mg} \mathrm{ha}^{-1}$ para os demais e a proporção da produção total do ano medida no inverno foi de $15 \%$ para o Tobiatã e $10 \%$ para Gren Panic e Makueni.

A participação de folhas na massa total de forragem do capim Atlas, durante o primeiro verão, foi menor que para o capim Massai e não diferiu dos demais capins (Tabela 5). No segundo verão, a proporção de folhas foi menor para o capim Atlas, que para capins Mombaça, Tanzânia e Tobiatã, não diferindo apenas daquela obtida para o 
Massai. No inverno os capins não apresentaram diferenças entre si. A proporção de folhas na forragem não variou entre os capins Massai, Mombaça, Tanzânia e Tobiatã em nenhuma das épocas analisadas.

Tabela 5. Proporção da massa de folhas na massa total de forragem em três épocas analisadas no último corte de acompanhamento da rebrotação, 28 (Atlas, Massai e Mombaça) e 35 dias (Tanzânia) no verão e 49 (Atlas, Massai e Mombaça) e 63 dias (Tanzânia) no inverno

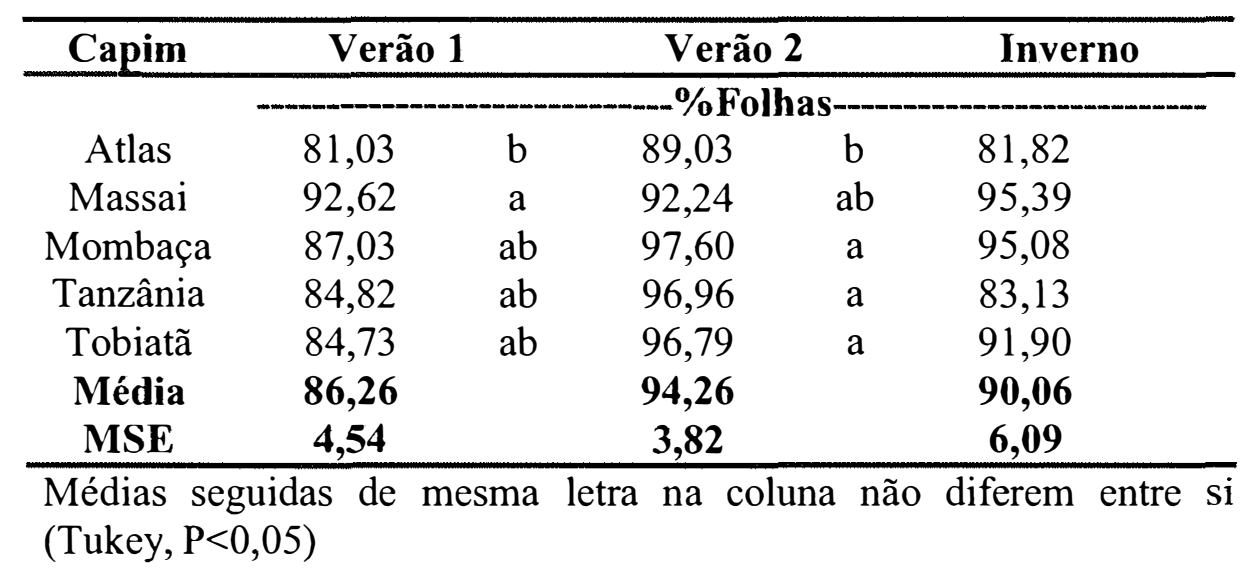

As proporções de folhas foram altas em todas as épocas do ano, sendo um indicativo que pode haver elevados consumos de matéria seca por animais em pastejo nestas condições, uma vez que o consumo de forragem e o conseqüente desempenho do animal são altamente influenciados pelos atributos da forragem consumida. Em trabalho realizado por Euclides et al. (1993) com Brachiaria spp, a massa de forragem não apresentou correlação com desempenho animal, mas a massa de folhas verdes foi positivamente correlacionada $(r=0,81)$ com ganho médio diário (GMD).

As alturas de corte adotadas, $15 \mathrm{~cm}$ para o Massai e $35 \mathrm{~cm}$ para os demais capins, pode ter contribuído para a elevada proporção de folhas encontrada na forragem colhida. Balsalobre (2002) trabalhou com três alturas de resíduo, baixo (800-1.800 kg MSV ha ${ }^{-1}$ ), média (2.500-3.300 $\mathrm{kg} \mathrm{MSV} \mathrm{ha}^{-1}$ ) e alta (3.100-5500 $\mathrm{kg} \mathrm{MSV} \mathrm{ha}^{-1}$ ), período de descanso de 33 dias e taxa de lotação variável, e obteve diferentes ofertas de folhas, sendo as maiores (19 a $28 \mathrm{~kg} \mathrm{MS} \mathrm{UA}^{-1} \mathrm{dia}^{-1}$ ) nos resíduos de maior massa pós pastejo

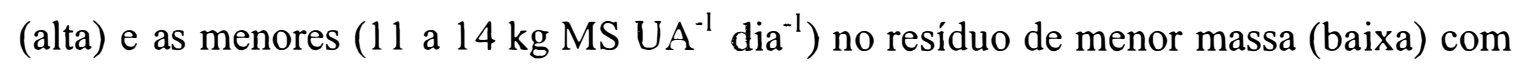


valores intermediários (15-18 $\left.\mathrm{kg} \mathrm{MS} \mathrm{UA}^{-1} \mathrm{dia}^{-1}\right)$ nos tratamentos de altura intermediário (média). Brâncio et al. (2003a) trabalharam com três dos capins avaliados, Tanzânia, Mombaça e Massai, e encontraram menores proporções de folhas nas amostras obtidas, nas diferentes épocas de avaliação realizadas (Junho/98, Setembro/98, Novembro/98 e Março/98), que as obtidas neste trabalho. Os valores médios alcançados por estes autores para a proporção de folhas na massa de forragem foram, respectivamente $43,2 \%$, 45,3\% e 43,7\% para Tanzânia, Mombaça e Massai. Esses valores inferiores ao deste trabalho pode ser explicado pela altura de corte utilizada para obtenção das amostras, que foi ao nível do solo naquele trabalho e 15 e $35 \mathrm{~cm}$ respectivamente para Massai e os demais capins neste estudo. Gerdes et al. (1998) trabalharam com Tanzânia, Setária cv. Kazangula (Setária sphacelata Stapf.) e Brachiaria brizantha cv. Marandu cortados a 15 $\mathrm{cm}$ do solo e obtiveram maiores proporções de lamina foliar na matéria seca na amostras de Tanzânia (84\%) que naquelas obtidas de setária (53\%) ou B. brizantha $(75 \%)$.

O capim Atlas produziu forragem com menor proporção de folhas que os demais e isso pode estar relacionado com o menor acúmulo de forragem obtida por este capim. Singhi et al. (1995) sugeriu que a maior quantidade de folhas pode ser um indicativo da produção e valor nutritivo de forragens obtidas a partir de genótipos de Panicum maximum (Jacq). Esses autores testaram seis genótipos de Panicum maximum (Jacq.) e os três genótipos mais produtivos (19 $\left.\mathrm{Mg} \mathrm{ha}^{-1} \mathrm{ano}^{-1}\right)$ apresentaram maior número de folhas por perfilho $(3-3,5)$ em relação aos menos produtivos $\left(15 \mathrm{Mg} \mathrm{ha}^{-1} \mathrm{ano}^{-1}\right)$, onde o número de folhas por perfilho foi menor (2).

Os resultados do presente trabalho sugerem que o acúmulo de massa, tanto nos dois verões como no inverno, corresponde a massa de folhas (Tabela 4 e Tabela 5). Estes dados corroboram com os de Gerdes et al. (1998), Brâncio at al. (2003a), Singh et al. (1995) e Balsalobre (2002). Silva (1977) trabalhou com capim buffel (Cenchrus ciliaris L.) e este capim apresentou taxa de acúmulo inicial de folhas superior ao de hastes, porém esta taxa se inverteu a partir de 42 dias do início da rebrotação. Queiroz Filho et al. (2000) avaliou a proporção de folhas durante o crescimento de capim-elefante (Pennisetum purpureum Schum.) e encontraram uma diminuição da proporção de folhas 
quando o capim foi cortado aos $40(74,4 \%), 60(62,9 \%), 80(51,4 \%)$ e 100 dias $(45,2 \%)$ em relação à massa total de forragem.

A participação de folhas na massa de forragem tende a diminuir à medida que a planta cresce (Figura 8), pois outros componentes do crescimento (hastes e material morto) que praticamente inexistem na fase inicial de rebrota passam a aumentar sua participação na massa de forragem (Figura 8). Resultados semelhantes foram obtidos por Santos et al. (1999), Gerdes et al. (1998) e Brito (1962).

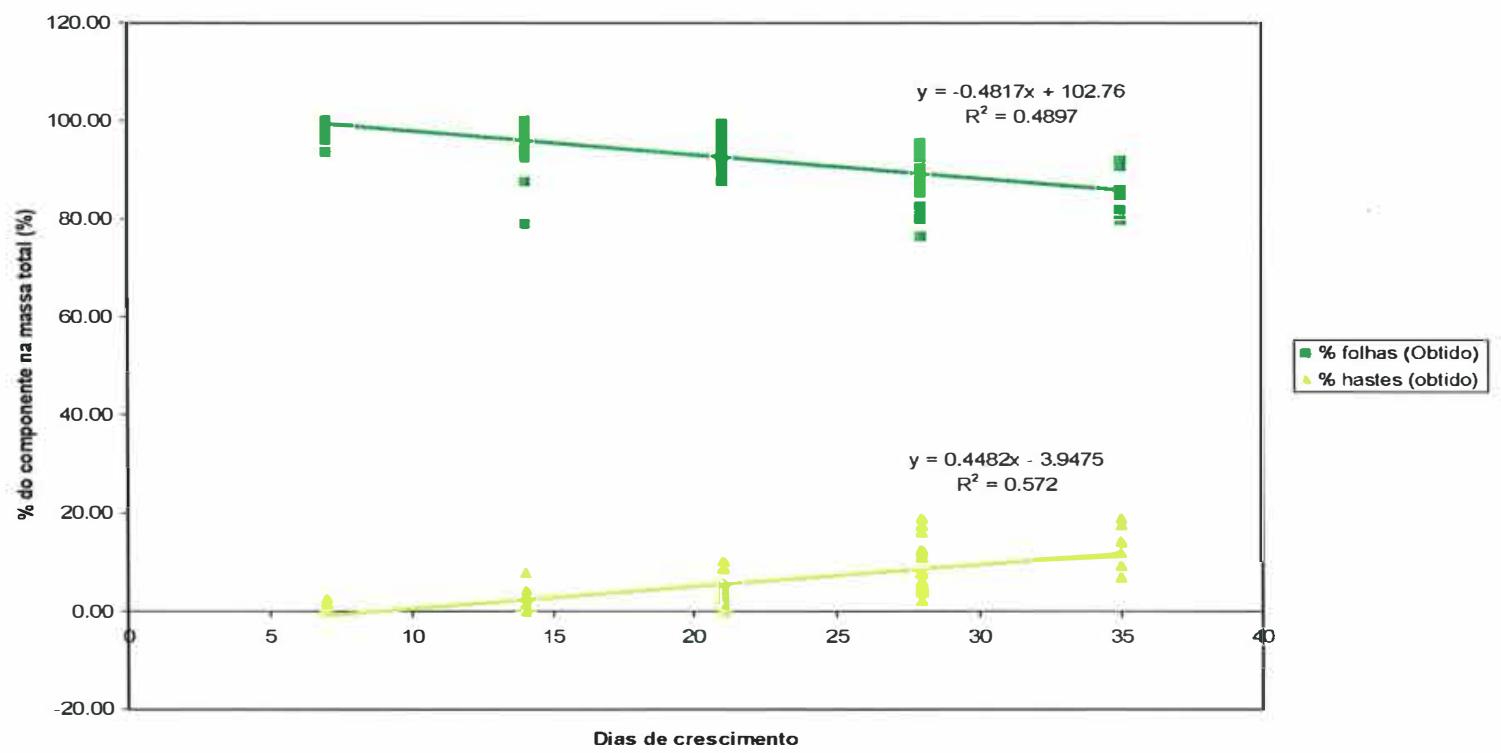

Figura 8 - Proporção de folhas e hastes ao longo de um corte de crescimento (primeiro verão), média de todos os capins

Nas amostragens semanais de acompanhamento da rebrotação foi acumulada pequena quantidade de hastes por todos os capins durante seu crescimento, média variando entre 3 e 12\% (Tabela 6). Maior proporção de hastes foi encontrada no capim Atlas, maior no Massai no primeiro verão e maior que Massai e Mombaça no inverno. Mombaça, Tanzânia e Tobiatã não diferiram entre si nem de Atlas e Massai nos dois verões. Durante o inverno a presença de hastes nos capins Massai e Mombaça foi muito pequena. 
Tabela 6. Participação da massa de hastes na massa total de forragem em três épocas analisadas no último corte de crescimento, 28 (Atlas, Massai e Mombaça) e 35 dias (Tanzânia) no verão e 49 (Atlas, Massai e Mombaça) e 63 dias (Tanzânia) no inverno

\begin{tabular}{|c|c|c|c|}
\hline Capim & Verão 1 & Verão 2 & Inverno \\
\hline & & Hastes-- & \\
\hline Atlas & 15,99 a & 6,24 & 12,42 a \\
\hline Massai & $4,68 \mathrm{~b}$ & 3,71 & $0,02 \quad \mathrm{c}$ \\
\hline Mombaça & $11,50 \mathrm{ab}$ & 1,82 & $0,68 \quad b c$ \\
\hline Tanzânia & $13,45 \quad a b$ & 1,60 & 4,78 abc \\
\hline Tobiatã & 13,29 ab & 1,11 & 1,77 abc \\
\hline Média & 11,66 & 3,03 & 3,74 \\
\hline MSE & 40.84 & 31.48 & 47.13 \\
\hline
\end{tabular}

Médias seguidas de mesma letra na coluna não diferem entre si (Tukey, $\mathrm{P}<0,05$ )

Santos et al. (1999) encontraram maiores proporções de hastes no verão e outono com Panicum maximum (Jacq.), cultivares Tanzânia e Mombaça, em experimento de pastejo não irrigado. Nas amostras avaliadas no verão (14/11/1995 a 17/02/1996) foram obtidas relação folha:haste entre 1,1 e 1,9 tanto para Tanzânia como Mombaça. No outono (06/04/1996 a 23/05/1996) estas relações diminuíram, ficando entre 0,4 e 1,0 para Tanzânia e 0,71 para Mombaça. Brâncio et al. (2003a) mediram pequena participação de hastes na massa total de forragem, em amostras colhidas ao nível do solo, em experimento de pastejo com Tanzânia, Mombaça e Massai e o capim Massai foi que menos acumulou hastes (média de 11\%) em comparação com o Tanzânia (média de 16\%) e Mombaça (19\%).

A pequena participação de hastes na massa de forragem medida no presente trabalho pode ser atribuída a três fatores principais: características morfológicas do gênero Panicum, altura de manejo e intervalo entre cortes. O gênero Panicum é constituído por espécies que quando manejadas adequadamente apresentam elevadas proporções de folhas comparativamente a outras espécies forrageiras tropicais. Gerdes et 
al.(1998) compararam três espécies (Panicum maximum (Jacq.) cv. Tanzânia, Setaria sphacelatta Stapf. cv Kazangula e Brachiaria brizantha cv. Marandu) cortados ao 21, 28 e 35 dias de maturidade e as amostras de $P$. maximum resultaram em $11 \%$ e $56 \%$ a mais de massa de folhas na matéria seca em relação, respectivamente, à $B$. brizantha e $S$. sphacelata. A maior quantidade de hastes se situou abaixo da altura de corte empregada neste trabalho. Moreno (2004) afirmou que mesmo mantendo a altura do resíduo constante durante o experimento, houve aumento da massa do resíduo, o que permitiu maior acúmulo do componente haste abaixo da altura de corte utilizada. No presente trabalho, as forrageiras foram cortadas quando o dossel já interceptava quase toda a radiação incidente e não muito posterior a esta fase quando há um aumento acentuado de massa de hastes e material morto, ou seja, no limite entre o período ideal e o de elevado acúmulo destes componentes. O momento da rebrotação em que o aumento de hastes começa a ser expressivo é muito próximo ao ponto de máxima taxa média de acúmulo, um indicativo de que a forragem colhida quando a taxa média de acúmulo é máxima contém baixa proporção de hastes, com interceptação média de luz de $96 \%$ no verão e 91\% no inverno (Moreno, 2004).

Ocorreu pequeno acúmulo de material morto acima do resíduo, não havendo diferença entre os capins, quanto à sua massa acumulada no primeiro verão (Tabela 7). No segundo verão, houve maior acúmulo de material morto para o capim Atlas, superior a todos os demais. No inverno o capim que apresentou maior acúmulo de material morto foi o Tanzânia.

A quantidade de material morto não foi elevada, mas o maior acúmulo de material morto no segundo verão para capim Atlas e no inverno para o Tanzânia pode ser conseqüência de um período de crescimento um pouco acima do ideal nestas épocas para esses cultivares. Moreno (2004) observou maior acúmulo de hastes e material morto quando o intervalo entre cortes foi superior a 95\% de interceptação luminosa. Brâncio et al. (2003a) encontrou proporções de material morto superiores às encontradas neste trabalho com amostras de capins Tanzânia, Mombaça e Massai, em experimento de pastejo amostrado ao nível do solo (valores médios entre 36\% e 45\%). Os dados obtidos para capim Massai por Brâncio et al. (2003a) contrastam com os do presente trabalho. 
Brâncio et al (2003a) obteve proporções de material morto para o capim Massai entre $29 \%$ e $56 \%$ em quatro épocas de coletas (junho/1998, setembro/1998, novembro/1998 e março de 1999) e estes valores não apresentaram diferenças em relação ao capim Tanzânia, mas foram superiores ao Mombaça. Neste trabalho, a massa de material morto do capim Massai não diferiu do Mombaça e foi inferior ao Tanzânia no inverno, provavelmente devido às diferenças de massa de resíduo empregado nos dois trabalhos. Naquele trabalho se manejou o Massai com massa de resíduo igual ao dos demais capins e neste a massa foi 50\% menor para Massai (Moreno, 2004).

Tabela 7. Participação da massa de material morto na massa total de forragem em três épocas analisadas no último corte de crescimento, 28 (Atlas, Massai e Mombaça) e 35 dias (Tanzânia) no verão e 49 (Atlas, Massai e Mombaça) e 63 dias (Tanzânia) no inverno

\begin{tabular}{crrrrrr}
\hline Capim & Verão 1 & Verão 2 & \multicolumn{2}{c}{ Inverno } \\
\cline { 2 - 7 } Atlas & 2,96 & a & 5,55 & a & 5,74 & b \\
Massai & 2,71 & a & 3,53 & ab & 4,59 & b \\
Mombaça & 1,47 & a & 0,44 & b & 4,23 & b \\
Tanzânia & 1,72 & a & 1,22 & b & 12,08 & a \\
Tobiatã & 1,97 & a & 1,09 & b & 6,32 & b \\
Média & $\mathbf{2 , 0 7}$ & $\mathbf{2 , 4 1}$ & $\mathbf{6 , 1 9}$ & \\
MSE & $\mathbf{2 , 1 0}$ & $\mathbf{1 , 5 7}$ & $\mathbf{2 , 2 8}$ & \\
\hline
\end{tabular}

Médias seguidas de mesma letra na coluna não diferem entre si (Tukey, $\mathrm{P}<0,05)$ 


\subsection{Caracterização física de capins de Panicum spp.}

\subsubsection{Densidade da forragem fresca}

A iniciativa de usar este tipo de análise foi testar um método de baixo custo e fácil realização e obter uma medida física da forragem que se relaciona-se aspectos físicos da digestão, uma vez que muitos métodos descritos pela literatura (GigerRiverdin, 2000; Akin et al., 1990) exigem aparelhos de elevado custo e nem sempre disponíveis. Pond et al. (1987) encontraram maior taxa de passagem e menor tempo de retenção ruminal para partículas da parte superior do rúmen, provavelmente a forragem de menor densidade, enquanto que o inverso foi observado para o material da parte inferior do rúmen, provavelmente de menor densidade.

A densidade da forragem fresca (DFF) não foi uma medida eficiente para diferenciar os capins e os valores obtidos foram iguais em todas as épocas acompanhadas $(\mathrm{P}<0,05)$. Os capins apresentavam proporções de seus componentes semelhantes e o método não se mostrou sensível para avaliar pequenas diferenças de densidade de um mesmo componente morfológico, por exemplo, folha. O método, porém foi eficiente para caracterizar os diferentes componentes morfológicos da planta (Tabela 8). A DFF de hastes foi superior às obtidas para planta toda, folhas e material morto. Ponde et al. (1987) encontraram maior presença de material originado de lâmians foliares nas partículas da parte superior do rúmen e maior presença de tecidos vasculares na parte inferior do rúmen.

Houve efeito de época na DFF de planta toda, folhas, haste e material morto (Tabela 8). Os valores de DFF obtidos no primeiro verão, para a planta toda e material morto foram superiores àqueles obtidos no segundo verão e no inverno e os resultados de folha e haste para o primeiro verão foram iguais aos do inverno e superiores aos do segundo verão. A DFF para material no primeiro verão foi o dobro das demais épocas, provavelmente porque este componente contém resíduo de haste e folha e a proporção entre ele pode afetar sua densidade. O primeiro verão foi a época que houve maior presença de haste na forragem (Tabela 8). 
Tabela 8. Densidade da forragem fresca da planta toda, folhas, hastes e material morto na forragem obtida nos cortes de acompanhamento da rebrotação (média de todos os capins)

\begin{tabular}{|c|c|c|c|c|}
\hline & Planta toda & Folha & Haste & M. Morto \\
\hline & & & & \\
\hline Verão 1 & 1,18 & 1,16 a & $1,31 \quad a$ & 1,18 \\
\hline Inverno & $0,77 \quad b$ & $1,03 \mathrm{ab}$ & $1,16 \mathrm{ab}$ & 0,60 \\
\hline Verão 2 & 0,82 & 0,84 & $0,89 \quad b$ & 0,68 \\
\hline Média & 0,98 B & 0,96 & 1,16 A & 0,87 \\
\hline
\end{tabular}

Médias seguidas de mesma letra minúscula na mesma coluna, ou letra maiúscula na mesma linha, não diferem entre si (Tukey, $\mathrm{P}<0,05)$

A haste foi o componente que apresentou maior DFF e isso pode ser usado como indicativo da proporção de hastes na forragem. A maior DFF para planta toda ocorreu no primeiro verão e este foi o que apresentou maior proporção de haste na forragem (117 g $\left.\mathrm{kg}^{-1}\right)$ em relação ao segundo verão $\left(30 \mathrm{~g} \mathrm{~kg}^{-1}\right)$ e inverno $\left(37 \mathrm{~g} \mathrm{~kg}^{-1}\right)$.

\subsubsection{Resistência ao cisalhamento}

Os capins apresentaram diferenças $(\mathrm{P}<0,05)$ quanto à resistência ao cisalhamento (Tabela 9). Os dados de folhas do capim Tobiatã indicam maior RC que todos os capins nos cortes efetuados a $2 / 3$ e quando esta medida foi feita a $1 / 3$ do comprimento, a $\mathrm{RC}$ não diferiu de Mombaça e foi superior aos demais capins. As hastes de Tobiatã também apresentaram maior RC, porém não diferiram dos resultados de hastes de Mombaça e Tanzânia.

O capim Mombaça não diferiu do Tobiatã quanto à RC de folhas (1/3) e hastes, porém foi superior aos demais capins. No corte a 2/3 do comprimento, RC de Mombaça foi semelhante ao do Tanzânia e inferior ao do Tobiatã e superior aos demais. Suas hastes apresentaram RC semelhantes aos valores de Tanzânia e Tobiatã e superiores a Atlas e Massai.

O Tanzânia apresentou menor resistência que o Tobiatã para cortes tanto a 1/3 como $2 / 3$ do comprimento de folhas e mas estes capins apresentaram igual RC para 
hastes. Atlas apresentou valores inferiores a Tobiatã, Tanzânia e Mombaça e superiores ao Massai. O capim Massai apresentou os menores valores de RC tanto para folhas como para hastes.

Quando se analisou o valor médio de todos os cultivares para folhas foi observado para cortes a 1/3 do comprimento, menor RC que a 2/3 do comprimento, que por sua vez foi menor que hastes a $1 / 3$ do comprimento, o qual apresentou menor $\mathrm{RC}$ que a cortes na haste a $2 / 3$ do comprimento. Houve efeito do local da amostragem na $\mathrm{RC}$ e também entre os componentes morfológicos. Componentes de maior valor nutritivo, folhas, apresentam menor RC que outros de menor valor nutritivo, hastes, sendo um bom indicativo do valor nutritivo e podendo ser usado para caracterizar forragens.

Tabela 9. Resistência ao cisalhamento de folhas e hastes de capins de Panicum spp.

\begin{tabular}{ccccccccc}
\hline CAPIM & FOLHAS (1/3) & FOLHAS (2/3) & HASTES (1/3) & HASTES (2/3) \\
\hline & 1,17 & $\mathrm{~b}$ & 1,35 & $\mathrm{c}$ & 1,96 & $\mathrm{~b}$ & 2,18 & $\mathrm{~b}$ \\
ATLAS & 0,93 & $\mathrm{c}$ & 1,01 & $\mathrm{~d}$ & 1,07 & $\mathrm{c}$ & 1,13 & $\mathrm{c}$ \\
MASSAI & 1,37 & $\mathrm{a}$ & 1,59 & $\mathrm{~b}$ & 3,16 & $\mathrm{a}$ & 3,36 & $\mathrm{a}$ \\
MOMBAÇA & 1,24 & $\mathrm{~b}$ & 1,51 & $\mathrm{~b}$ & 3,31 & $\mathrm{a}$ & 3,63 & $\mathrm{a}$ \\
TANZÂNIA & 1,40 & $\mathrm{a}$ & 1,67 & $\mathrm{a}$ & 3,46 & $\mathrm{a}$ & 3,86 & $\mathrm{a}$ \\
TOBIATÃ & 1,19 & $\mathrm{D}$ & 1,40 & $\mathrm{C}$ & 2,62 & $\mathrm{~B}$ & 2,88 & $\mathrm{~A}$ \\
MÉDIAS & $1,0 .-k g$ & &
\end{tabular}

Médias de mesma letra minúscula, na coluna, ou maiúscula, na mesma linha, não diferem entre si (Tukey, $\mathrm{P}<0,05)$

Os valores de RC para folhas, 1/3 e 2/3 do comprimento, foram inferiores àqueles encontrados por Hughes et al. (1998) que estudaram quatro espécies de Brachiaria spp quanto à RC de folhas, em duas idades de corte (4 e 6 semanas) e encontraram diferenças entre as espécies, porém elas não existiram entre idades. Foram observados, na média das duas idades, em Brachiaria brizantha $(2,73 \mathrm{~kg})$ maiores valores de $\mathrm{RC}$ que $B$. humidicula $(1,9 \mathrm{~kg})$, . decumbens $(1,4 \mathrm{~kg})$ e B. ruziziensis $(1,2$ $\mathrm{kg}$ ). Henry et al. (1996) encontrou diferenças entre cinco espécies forrageiras (Dactilis glomerata, Festuca arundinacea, Lolium perene, Phalaris aquática e Thinopyrum 
ponticum) quanto à RC. O L. perenne $(6,2 \mathrm{~N})$ apresentou menor $\mathrm{RC}$ que $D$. glomerata $=$ $P$. aquática $=T$. ponticum $(12,4 \mathrm{~N})$ que foram menores que $F$. arundinacea $(15,6 \mathrm{~N})$.

Iwaasa (1998) mediu resistência ao cisalhamento de hastes de capins de alfafa e classificou os segmentos de haste em três: inferior, meio e superior. De modo diferente ao que ocorreu neste trabalho, a parte inferior (93,9 a 132,9 N) apresentou maior RC que o meio $(50,2$ a $73,0 \mathrm{~N})$ o qual apresentou maior que a parte superior das hastes $(11,4 \mathrm{a}$ $17,2 \mathrm{~N}$ ). Os autores encontraram elevada correlação entre $\mathrm{RC}$ e diâmetro das hastes ( $\mathrm{r}$ entre 0,58 a 0,91, P,0,01). Naquele trabalho, a parte inferior da haste $(2,11$ a 2,59 mm) apresentava maior diâmetro que o meio $(1,78$ a $2,31 \mathrm{~mm})$ e este maior que a parte superior $(0,87$ a $1,1 \mathrm{~mm})$. Neste estudo a média do diâmetro de hastes foi 0,35 (1/3 do comprimento) e $0,42 \mathrm{~cm}$ (2/3 do comprimento).

A resistência ao cisalhamento apresentou correlação $(\mathrm{P}<0,05)$ com o valor nutritivo da forragem (Tabela 10) Os teores de hemicelulose, FDN, matéria mineral, além da digestibilidade da FDN e da FDA se correlacionaram positivamente com a resistência ao cisalhamento enquanto que a correlação com o teor proteína foi negativa. A digestibilidade da matéria seca e da matéria orgânica e lignina não apresentaram correlação significativa com a resistência ao cisalhamento. Os carboidratos estruturais dos tecidos vegetais têm como uma de suas funções principais conferir resistência e sustentação à planta dando rigidez aos tecidos onde estão presentes. Hughes et al. (1998) estudaram resistência ao cisalhamento e à moagem de quatro espécies de Brachiaria e encontraram diferenças na resistência ao cisalhamento entre as espécies estudadas. Naquele estudo, as forças necessárias ao cisalhamento e composição da fibra apresentaram correlação positiva $(\mathrm{P}<0,05)$ entre resistência ao cisalhamento e características morfológicas: área $(\mathrm{r}=0,67)$, peso $(\mathrm{r}=0,70)$ e comprimento de folhas $(\mathrm{r}$ $=0,82)$ e composição química: FDN $(\mathrm{r}=0,65)$; FDA $(\mathrm{r}=0,76)$ e celulose $(\mathrm{r}=0,77)$. Os autores sugeriram que os arranjos estruturais dos tecidos e os padrões de lignificação merecem ser estudado assim como estudos de anatomia foliar a fim de caracterizar melhor, as folhas das espécies estudadas. Iwaasa et al. (1998) encontrou correlação significativa entre $\mathrm{RC}$ e $\mathrm{FDN}(\mathrm{r}=0,26, \mathrm{P}<0.05)$, FDA $(\mathrm{r}=0,32, \mathrm{P}<0.01)$ na parte 
superior das hastes e FDA $(r=0,28, \mathrm{P}<0.05), \operatorname{HEM}(\mathrm{r}=-0.42, \mathrm{P}<0.001)$ e $\operatorname{CEL}((\mathrm{r}=0,40$, $\mathrm{P}<0.001$ ) na parte inferior.

Tabela 10. Correlação entre resistência ao cisalhamento e componentes do valor nutritivo de capins de Panicum spp.

\begin{tabular}{cccccccccc}
\hline COMPONENTE & HEM & FDN & PB & MM & DMS & DMO & DFDN & DFDA & LIG \\
\hline$r$ & 0,403 & 0,437 & 0,474 & 0,515 & ns & ns & 0,193 & 0,229 & ns \\
\hline$(\mathrm{P}<0,05)$ & & & & & & & & &
\end{tabular}

\subsubsection{Resistência à moagem}

A resistência à moagem (RM) foi expressa como a quantidade de material de resistente à moagem em relação ao peso total da amostra moída. $\mathrm{Na}$ amostras do primeiro verão (Tabela 11), foram encontradas diferenças entre capins para os componentes analisados. A RM foi maior Massai e menor par Mombaça para planta toda, folhas e haste, tendo sido intermediário para os demais capins. Os valores de RM nas hastes foram maiores para Massai.

Tabela 11. Resistência à moagem - Proporção da amostra resistente à moagem na planta toda, em folhas, hastes e material morto da forragem obtida nos cortes de acompanhamento da rebrotação do primeiro verão

\begin{tabular}{ccccccccc}
\hline CAPIM & PLANTA TODA & FOLHAS & HASTES & MATERIAL MORTO \\
\hline ATLAS & 0,72 & ab & 0,70 & ab & 0,75 & b & 0,85 & a \\
MASSAI & 0,74 & a & 0,74 & a & 0,95 & $\mathrm{a}$ & 0,77 & b \\
MOMBAÇA & 0,66 & $\mathrm{c}$ & 0,67 & $\mathrm{~b}$ & 0,85 & $\mathrm{~b}$ & 0,78 & $\mathrm{~b}$ \\
TANZÂNIA & 0,69 & $\mathrm{bc}$ & 0,66 & $\mathrm{~b}$ & 0,80 & $\mathrm{~b}$ & 0,82 & $\mathrm{ab}$ \\
TOBIATÃ & 0,70 & $\mathrm{bc}$ & 0,70 & $\mathrm{ab}$ & 0,78 & $\mathrm{~b}$ & 0,77 & $\mathrm{~b}$ \\
\hline
\end{tabular}

Médias seguidas de mesma letra, na mesma coluna, não diferem entre si (Tukey, $\mathrm{P}<0,05$ ) 
Hughes et al (1998) estudaram quatro espécies de Brachiaria spp quanto à RM de folhas, em duas maturidades (4 e 6 semanas) e encontraram diferenças entre espécies e idades. As plantas colhidas com 4 semanas apresentavam menor RM $\left(0,76 \mathrm{~g} \mathrm{~g}^{-1}\right)$, eram mais macias, que as de 6 semanas $\left(0,83 \mathrm{~g} \mathrm{~g}^{-1}\right)$. Para Brachiaria brizantha $\left(0,79 \mathrm{~g} \mathrm{~g}^{-1}\right)$ foram maiores que para $B$. humidicula $\left(0,81 \mathrm{~g} \mathrm{~g}^{-1}\right), B$. decumbens $\left(0,81 \mathrm{~g} \mathrm{~g}^{-1}\right)$ e $B$. ruziziensis $\left(0,77 \mathrm{~g} \mathrm{~g}^{-1}\right)$. Os dados indicam uma menor RM neste trabalho, com Panicum ssp, a medida por Hughes et al. (1998), com Brachiaria spp.

Nas amostras de crescimento, se analisou o resultado nos cortes finais de crescimento. A RM foi a mesma entre capins $(\mathrm{P}<0,05)$ para planta toda, folhas e material morto, no segundo verão. Para hastes, a RM para o capim Atlas foi menor que para Mombaça não diferindo dos demais capins que não diferiram entre si (Tabela 12). Também no segundo verão, os valores de RM encontrados para folhas foram menores que os encontrados por Hughes et al. (1998).

Tabela 12. Resistência à moagem - Proporção da amostra resistente à moagem, na planta toda, em folhas, hastes e material morto da forragem obtida nos cortes de acompanhamento da rebrotação do segundo verão

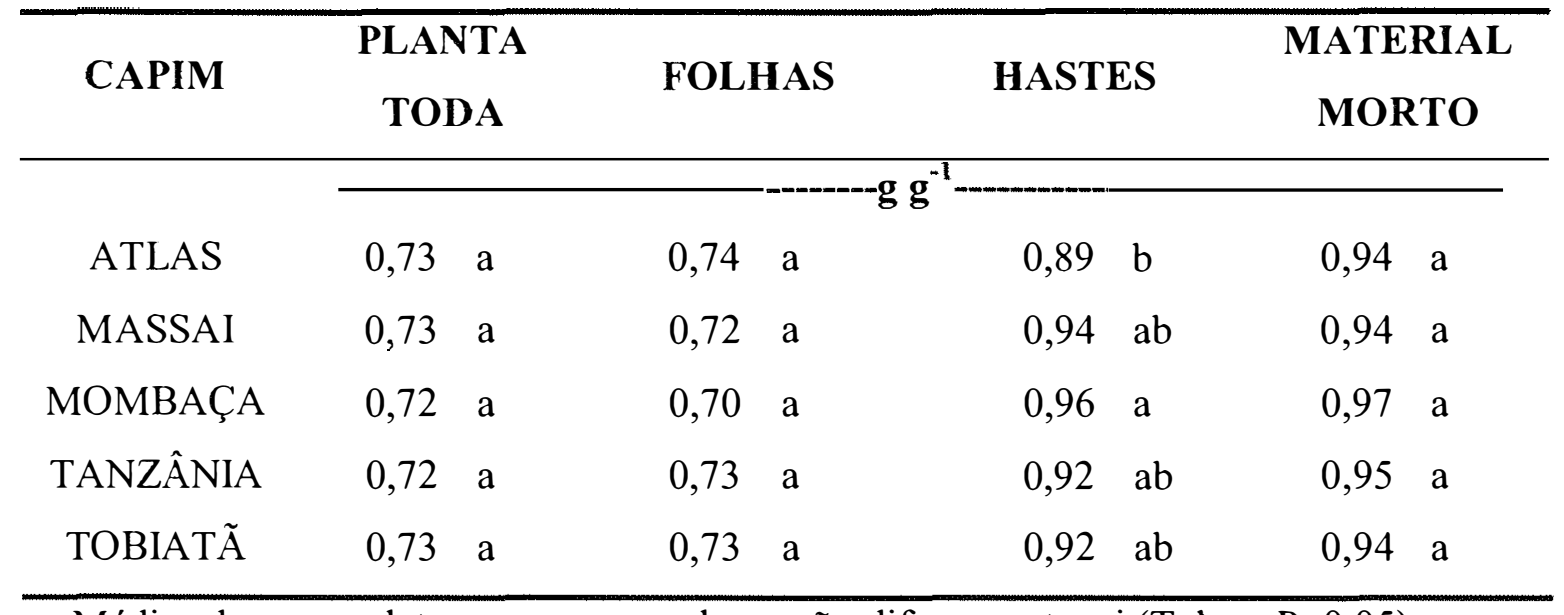

Médias de mesma letra, na mesma coluna, não diferem entre si (Tukey, $\mathrm{P}<0,05)$

No inverno, não foi obsevado deiferenças entre os capins quantoa à resistência à moagem $(\mathrm{RM})$ para planta toda, folhas e material morto $(\mathrm{P}<0,05)$. Quando se comparou hastes, a RM de Mombaça, Tobiatã e Massai foram superiores aos capins Atlas e 
Tanzânia (Tabela 13). No inverno assim como no verão, os valores de RM encontrados para folhas foram menores que os encontrados por Hughes et al. (1998).

Tabela 13. Resistência à moagem - Proporção da amostra, na planta toda, em folhas, hastes e material morto da forragem obtida nos cortes de acompanhamento da rebrotação (Inverno)

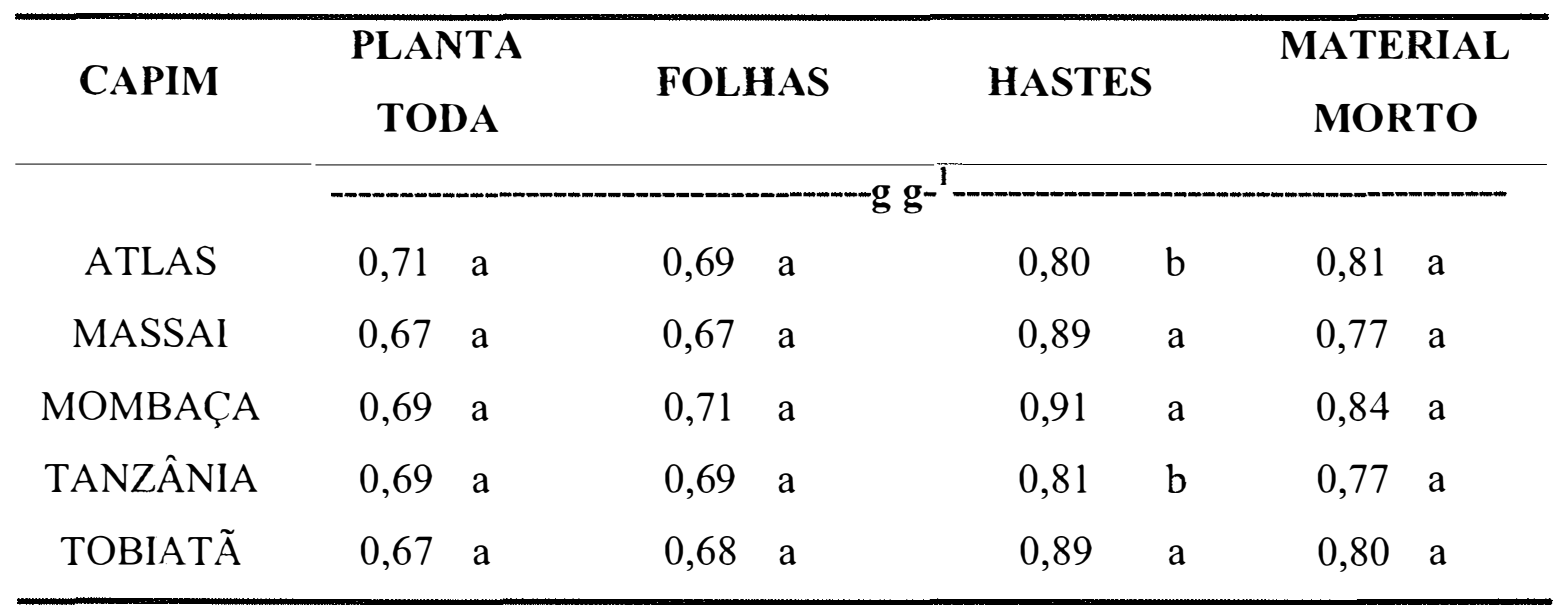

Médias de mesma letra, na mesma coluna, não diferem entre si (Tukey, $\mathrm{P}<0,05)$

\subsubsection{Densidade da forragem seca moída}

Não houve diferença de densidade da forragem moída entre os capins nas diferentes épocas de corte $(\mathrm{P}<0,05)$, verão $1\left(\right.$ média $\left.=0,24 \mathrm{~g} \mathrm{~mL}^{-1}\right)$, inverno (média $=$ $0,24 \mathrm{~g} \mathrm{~mL}^{-1}$ ) e verão 2 (média $=0,25 \mathrm{~g} \mathrm{~mL}^{-1}$ ), quando se comparou as médias de planta toda e folhas. Para as frações, haste e material, morto não houve material suficiente para as análises.

\subsubsection{Tamanho médio de partículas}

Os capins avaliados apresentaram diferenças quanto a tamanho médio de partícula (TMP) nas amostras obtidas nos cortes finais de acompanhamento, 28 dias no verão para Atlas, Massai e Mombaça e 35 dias para Tanzânia e Mombaça e no inverno 
49 dias para Atlas, Massai e Mombaça e 63 dias para Tobiatã. No primeiro verão (Tabela 14), o tamanho médio de partícula (TMP) da planta toda e folhas para os capins Mombaça, Tanzânia e Tobiatã foram maiores que para Atlas e Massai. Para o Massai, o tamanho médio de partículas de folhas foi igual aos dos demais capins. Hastes de Atlas e Tanzânia foram não diferiram quanto ao TMP, porém o TMP foi maior que os obtidos para Mombaça e Tobiatã.

Tabela 14. Tamanho médio de partícula da planta toda, folhas e hastes da forragem obtida nos cortes de acompanhamento da rebrotação do primeiro verão

\begin{tabular}{|c|c|c|c|}
\hline CAPIM & PLANTA TODA & FOLHAS & HASTES \\
\hline ATLAS & $0,18 \quad b$ & $0,18 \quad b$ & 0,26 a \\
\hline MASSAI & $0,19 \quad b$ & $0,21 \quad a b$ & $---\quad--$ \\
\hline MOMBAÇA & 0,21 a & 0,22 a & $0,22 \quad b$ \\
\hline TANZÂNIA & 0,21 a & $0,20 \quad a b$ & 0,26 a \\
\hline TOBIATÃ & $0,22 \quad a$ & $0,21 \quad a b$ & $0,23 \quad b$ \\
\hline MÉDIA & $0,21 \mathrm{~B}$ & $0,20 \mathrm{~B}$ & $0,24 \mathrm{~A}$ \\
\hline EPM & 0,02 & 0.04 & 0,02 \\
\hline
\end{tabular}

Médias de mesma letra minúscula na mesma coluna e letra maiúscula na mesma linha não diferem entre si (Tukey, $\mathrm{P}<0,05)$.

Hastes de Massai e material morto de todos os capins não apresentaram material suficiente para avaliação.

O TMP obtido com hastes foi superior ao de folhas e de planta toda. Hastes apresentaram maior TMP e isso pode estar relacionado com a maior resistência à degradação desta fração no rúmen. Deschamps (1999) encontrou maior degradabilidade de folhas em relação às de hastes quando estudou valor nutritivo de capim elefante (Pennisetum purpureum, Schum.) cortado a cada duas semanas até 126 após o corte inicial. A degradação de MS de folhas foi superior a de hastes em todas as idades de corte variando entre 784 e $539 \mathrm{~g} \mathrm{~kg}^{-1}$ e 763 e $373 \mathrm{~g} \mathrm{~kg}^{-1}$ respectivamente para folhas e hastes. Giger-Riverdin (2000) não encontrou correlação entre a distribuição média de 
tamanho de partículas e parâmetros químicos da planta. Pond et al. (1987) estudaram o tamanho de partículas do bolo alimentar, estrato superior e inferior do rúmen e fezes de animais pastejando capim bermuda cv. Coastal (Cynodon spp.) com duas maturidades (20 e 42 dias de rebrotação) e duas digestibilidades da matéria seca (548 e $643 \mathrm{~g} \mathrm{~kg}^{-1}$ ) e encontraram maior tamanho de partícula no estrato superior do rúmen em relação ao estrato inferior, tanto para animais pastejando forragens imaturas como mais maduras. Apesar da diferença de tamanho de partícula encontrado nos dois estratos foi observado que o tamanho nas fezes sempre foi menor que nos estratos, indicando a necessidade de redução de tamanho do alimento para que o alimento deixe o rúmen.

No segundo verão (Tabela 15), a TMP da planta toda para o capim Tobiatã foi maior que para o capim Atlas, porém o TMP dos demais capins não diferiram de Atlas ou Tobiatã. Nas folhas, os valores de TMP não diferiram entre si. Valores de TMP de hastes de Mombaça e Tanzânia não diferiram entre si, porém foram superiores aos de Atlas e Massai. O TMP para hastes de Tobiatã não diferiu dos demais capins. O TMP de hastes também nesta época foram superiores aos de folhas e de planta toda. 
Tabela 15. Tamanho médio de partícula da planta toda, folhas e hastes da forragem obtida nos cortes de acompanhamento da rebrotação do segundo verão

\begin{tabular}{|c|c|c|c|}
\hline CAPIM & PLANTA TODA & FOLHAS & HASTES \\
\hline & & ---mm--- & 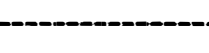 \\
\hline ATLAS & $0,18 \quad b$ & 0,20 & $0,24 \quad \mathrm{~b}$ \\
\hline MASSAI & 0,21 ab & 0,20 & $0,24 \quad \mathrm{~b}$ \\
\hline MOMBAÇA & $0,19 \quad b$ & 0,20 & $0,28 \quad \mathrm{a}$ \\
\hline TANZÂNIA & $0,20 \quad a b$ & 0,22 & $0,28 \quad \mathrm{a}$ \\
\hline TOBIATÃ & $0,23 \quad \mathrm{a}$ & 0,23 & $0,26 \mathrm{ab}$ \\
\hline MÉDIA & $0,21 \mathrm{~B}$ & $0,21 \mathrm{~B}$ & $0.27 \mathrm{~A}$ \\
\hline EPM & 0,05 & 0,05 & 0,02 \\
\hline
\end{tabular}

Médias seguidas de mesma letra minúscula na mesma coluna e letra maiúscula na mesma linha não diferem entre si (Tukey, $\mathrm{P}<0,05)$.

Durante o inverno (Tabela 16), os maiores de TMPs na planta toda foram obtidos no Tobiatã, resultados que não diferiram daqueles de Tanzânia e Mombaça, porém superiores aos valores de Atlas e Massai. Na folhas os valores de TMP de Tobiatã foram superiores aos TMPs de Atlas e Massai e não diferiram de Mombaça e Tanzânia. As amostras de hastes, no inverno, apresentaram quantidades reduzidas de material, sendo possível apenas analisar os valores de Atlas e Tanzânia que apresentaram valores que não diferiram entre si no TMP. No material morto de Mombaça o TMP foi superior a todos os demais capins, que não diferiram entre si. O material morto apresentou maior TMP, superior ao de hastes superiores por sua vez ao de folhas e planta toda, os quais não diferiram entre si. 
Tabela 16. Tamanho médio de partícula da planta toda, folhas e hastes da forragem obtida nos cortes de acompanhamento da rebrotação (Inverno)

\begin{tabular}{ccccccccc}
\hline CAPIM & $\begin{array}{c}\text { PLANTA } \\
\text { TODA }\end{array}$ & FOLHAS & HASTES & $\begin{array}{c}\text { MATERIAL } \\
\text { MORTO }\end{array}$ \\
\hline ATLAS & 0,16 & $\mathrm{c}$ & 0,16 & $\mathrm{c}$ & 0,23 & & 0,26 & $\mathrm{~b}$ \\
MASSAI & 0,19 & $\mathrm{bc}$ & 0,19 & $\mathrm{bc}$ & -- & -- & 0,24 & $\mathrm{~b}$ \\
MOMBAÇA & 0,20 & $\mathrm{abc}$ & 0,20 & $\mathrm{abc}$ & -- & -- & 0,32 & $\mathrm{a}$ \\
TANZÂNIA & 0,21 & $\mathrm{ab}$ & 0,21 & $\mathrm{ab}$ & 0,23 & & 0,26 & $\mathrm{~b}$ \\
TOBIATÃ & 0,23 & $\mathrm{a}$ & 0,23 & $\mathrm{a}$ & -- & -- & 0,27 & $\mathrm{~b}$ \\
MÉDIA & $0,20 \mathrm{C}$ & $0,20 \mathrm{C}$ & $0,23 \mathrm{~B}$ & $0,27 \mathrm{~A}$ & \\
EPM & 0,04 & 0,04 & 0,01 & 0,03 & \\
\hline
\end{tabular}

Médias de mesma letra minúscula na mesma coluna e letra maiúscula na mesma linha não diferem entre si (Tukey, $\mathrm{P}<0,05)$.

As amostras de haste dos capins Massai, Mombaça e Tobiatã não foram suficientes para avaliação.

Os capins podem ser classificados quanto ao TMP: Atlas e Massai, com menor TMP e Mombaça, Tanzânia e Tobiatã com TMO mais alto. A utilização de características físicas para diferenciar materiais pode ser uma poderosa ferramenta na identificação de valor nurritivo superior em programas de melhoramento e seleção (Hughes et al., 2000). A seleção de genótipos com características físicas desejáveis podem aumentar digestibilidade e o potencial de consumo voluntário de forragem (lwaasa et al., 1998). Mackinnon et al. (1988) afirmaram que a seleção de azevém (Lolium perenne) utilizando-se caracterização física reduziram a concentração de celulose e hemicelulose, aumentou levemente a concentração de nitrogênio e elevou a taxa de consumo de matéria seca, por carneiros (17\%) mas não afetou a taxa de degradação ruminal da matéria seca.

A caracterização de forragens utilizando PMP também foi eficiente na classificação dos componentes diferenciando bem folhas, hastes e material morto. A 
caracterização física pode ser também utilizada para caracterizar e diferenciar alimentos (Giger-Riverdin, 2000).

\subsection{Caracterização químico-bromatológica de capins Panicum spp.}

A digestibilidade da matéria orgânica foi diferente entre os capins $(\mathrm{P}<0,05)$. $\mathrm{O}$ capim Atlas foi o de maior digestibilidade, semelhante a Mombaça. Este por sua vez, teve valores de DIVMO foi semelhante a Tobiatã e superior aos demais capins. $\mathrm{O}$ valor do capim Massai foi semelhante ao de Tobiatã e Tanzânia, enquanto que o menor valor foi encontrado para o capim Tanzânia (Tabela 17).

Tabela 17. DIVMO, DIVMS e concentração de PB na forragem obtida na média de todos cortes de produção

\begin{tabular}{|c|c|c|c|}
\hline CAPIM & DIVMO média & DIVMS média & Teor médio de PB \\
\hline & & - $\mathrm{g} \mathrm{kg}^{-1}$ & \\
\hline ATLAS & 695,92 & 724,68 & 159,42 \\
\hline MASSAI & 664,22 & 665,82 & 141,30 \\
\hline MOMBAÇA & 681,99 & 718,85 & 156,08 \\
\hline TANZÂNIA & $647,31 \quad d$ & 666,40 & 133,79 \\
\hline TOBIAT $\tilde{A}$ & 671,99 & 700,32 & 133,01 \\
\hline EPM & 50,85 & 4,14 & 18,74 \\
\hline
\end{tabular}

Médias seguidas de mesma letra, na coluna, não diferem entre si (Tukey, $\mathrm{P}<0,05)$.

Os capins apresentaram digestibilidade elevada. Brâncio et al. (2003a) estudaram a composição da dieta selecionada por animais pastejando Tanzânia, Mombaça e Massai e encontraram valores de DIVMO inferiores aos deste trabalho. A DIVMO para Tanzânia, Mombaça e Massai, naquele estudo, se situou entre 500 e $600 \mathrm{~g} \mathrm{~kg}^{-1}$, sendo sempre menor para Massai nas épocas estudadas (setembro e novembro de 1998 e março de 1998. Fernandes et al. (2004) avaliaram a qualidade de laminas foliares de 24 materiais de Panicum spp., e encontraram valores para os capins Mombaça (577 a $696 \mathrm{~g}$ $\mathrm{kg}^{-1}$ ), Tanzânia (653 a $736 \mathrm{~g} \mathrm{~kg}^{-1}$ ) e Massai (544 a $712 \mathrm{~g} \mathrm{~kg}^{-1}$ ) semelhantes aos 
encontrados neste trabalho. Fernandes et al. (2004) encontrou efeito de época, onde no primeiro e segundo corte (respectivamente, 05/02/2003 e 12/03/2003) os valores para Mombaça foram menores que para o capim Massai, enquanto que no terceiro e quarto corte (respectivamente, 16/04/2003 e 25/06/2003), os valores para Massai foram maiores. Os valores do capim Tanzânia foram superiores no segundo, terceiro e quarto corte aos de Massai e Tanzânia.

As diferenças de digestibilidade podem estar relacionadas à composição de tecidos presentes nas plantas. Akin \& Burdick (1975) afirmaram que as características micro-anatômicas da parede celular podem afetar a degradabilidade por microorganismos. Naquele estudo, os autores encontraram maior degradabilidade para floema e bainhas parenquimáticas e mesófilo, intermediário para epiderme e considerou indegradáveis tecidos vasculares lignificados e esclerênquima. Neste trabalho, foram feitos cortes exploratórios de lâminas foliares dos capins (Figura 9) e avaliado a área dos tecidos em secções transversais usando-se o software AutoCAD MAP 2000, onde se determinou menores porcentagem na área da secção transversal de esclerênquima e xilema para lâminas de Atlas $(9,8 \%)$ seguido por Tobiatã $(12,1 \%)$, Tanzânia $(15,3 \%)$, Massai (16,6\%) e Mombaça (17,1\%). A área de floema medida foi maior para Mombaça (12,2\%), seguido por Tanzânia (10,1\%) e Atlas (7,9\%). Os valores para Tobiatã (1,0\%) e Massai $(1,3 \%)$ podem ter sido subestimados pelo método usado na medição da área da secção. Lempp et al.(2004) encontraram menores valores para área de seção de esclerênquima e tecidos vasculares $(6 \%)$ e estes autores não encontraram efeito de maturidade nas áreas de secções de tecidos. Paciullo et al. (2002) encontrou menor degradabilidade do mesofilo e parênquima com o aumento da idade da planta. Ventrella et al. (1997) estudaram anatomia e composição químico-bromatológica de três espécies de Cynodon spp.( C. dactylon, $C$ - plectostanachyus e C.nlemfuensis), cortadas em duas épocas (verão e inverno) e encontraram melhor proporções de tecidos facilmente digeridos assim como melhor composição bromatológica no inverno. Entre as espécies, C. dactylon mostrou valor nutritivo superior e $C$-nlemfuensis a menor digestibilidade. Brito et al. (1997a) estudaram alterações histológicas em três cultivares de capim elefante (P. purpureum) (Roxo, EMPASC 307 Testo e EMPASC 309 Areia), em três 
idades de rebrotação ( 4,8 e 16 semanas), submetidos a três tempos de incubação em líquido ruminal (6, 24 e 48 horas). Os autores não encontraram diferenças anatômicas entre os cultivares, mas o cultivar Roxo apresentou maior proporção de lignina no caule e a bainha apresentou grande área de degradação mesmo com o envelhecimento dos tecidos, que aumentou a porcentagem de tecidos lignificados em todos os órgãos.

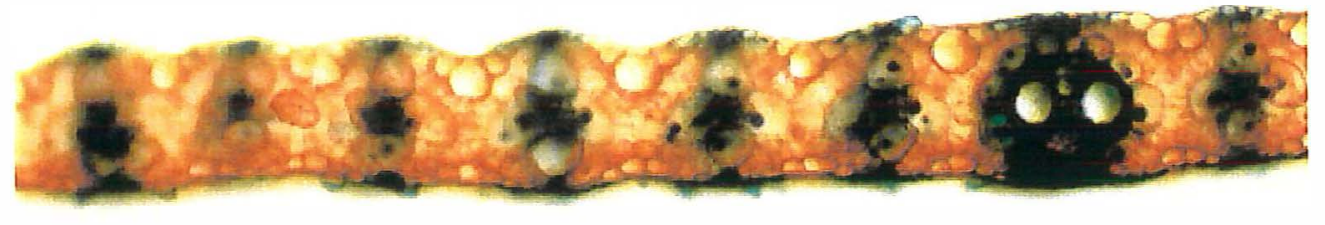

Atlas

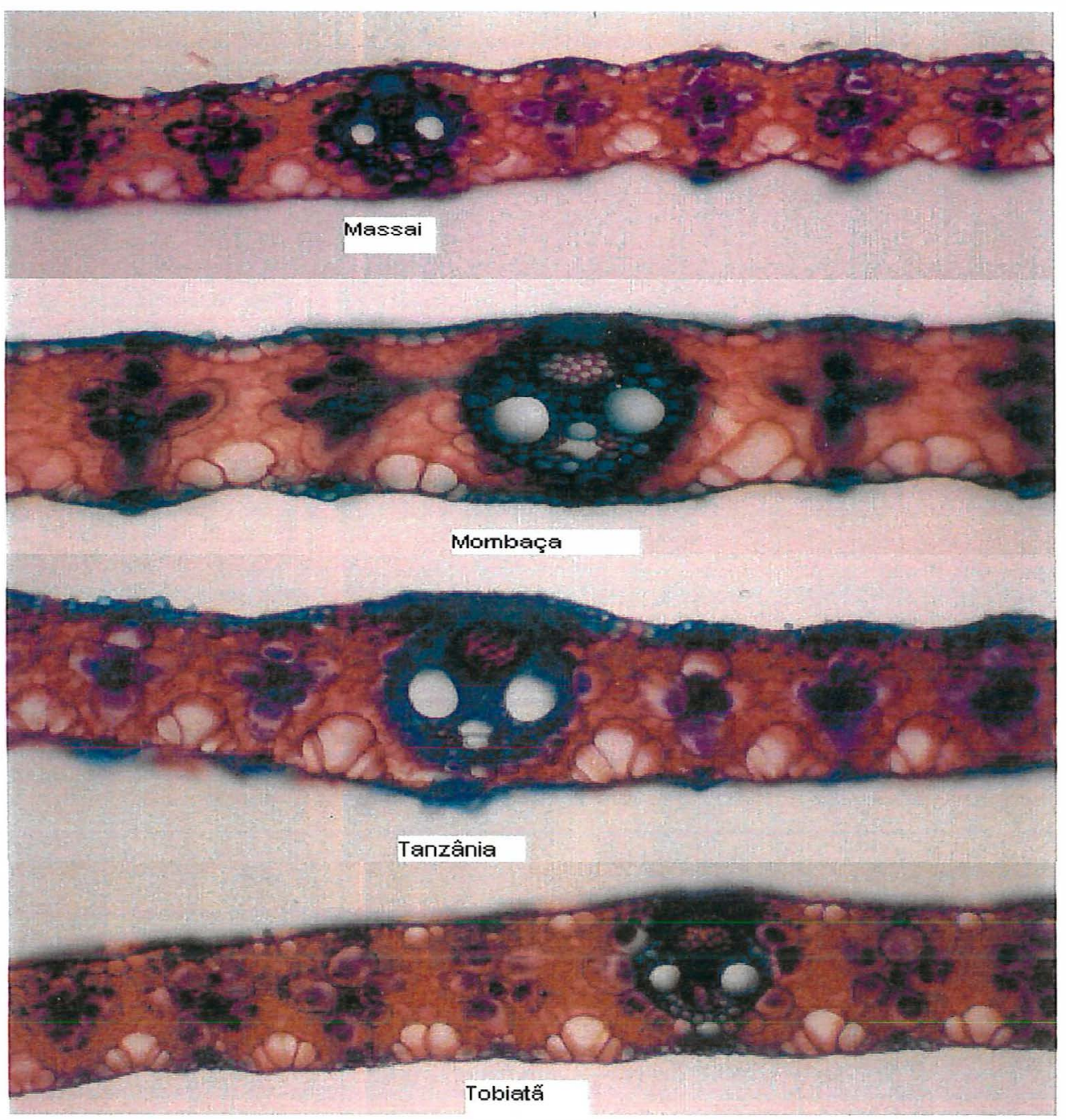

Figura 9 - Cortes anatômicos de lâminas foliares de capins de Panicum spp. 
Os valores encontrados para DIVMS foram parecidos aos de DIVMO. A DIVMS para Atlas $\left(725 \mathrm{~g} \mathrm{~kg}^{-1}\right)$ foi igual à obtida para Mombaça $\left(719 \mathrm{~g} \mathrm{~kg}^{-1}\right)$. A digestibilidade de Mombaça foi igual à conseguida para o capim Tobiatã $\left(700 \mathrm{~g} \mathrm{~kg}^{-1}\right)$ e este foi superior a Massai (665 $\left.\mathrm{g} \mathrm{kg}^{-1}\right)$ e Tanzânia $\left(666 \mathrm{~g} \mathrm{~kg}^{-1}\right)$ que por sua vez, não diferiram entre si. Postiglioni et al. (2004) encontraram valores análogos de DIVMS para Tanzânia (647 a $731 \mathrm{~g} \mathrm{~kg}^{-1}$ ), Mombaça (621 a $697 \mathrm{~g} \mathrm{~kg}^{-1}$ ) e Tobiatã (607 a $700 \mathrm{~g} \mathrm{~kg}^{-1}$ ). Gonçalves et al.(2004) obteve valores de DIVMS para Panicum maximum cv. Tobiatã de $609 \mathrm{~g} \mathrm{~kg}^{-1} \mathrm{e}$ $572 \mathrm{~g} \mathrm{~kg}^{-1}$, respectivamente para folhas e hastes.

O conteúdo de proteína bruta foi diferente entre os capins, sendo maior para Atlas $\left(159 \mathrm{~g} \mathrm{~kg}^{-1}\right)$ e Mombaça $\left(156 \mathrm{~g} \mathrm{~kg}^{-1}\right)$ seguido por Massai $\left(141 \mathrm{~g} \mathrm{~kg}^{-1}\right)$ que foi superior a Tanzânia (134 $\left.\mathrm{g} \mathrm{kg}^{-1}\right)$ e Tobiatã (133 $\left.\mathrm{g} \mathrm{kg}^{-1}\right)$ que não diferiram entre si. $\mathrm{O}$ Mombaça apresentou valores de PB semelhante aos do capim Massai e superior a Tanzânia e Mombaça. Não houve diferença entre Massai, Tanzânia e Tobiatã quanto aos teores de proteína (Tabela 17). Machado et al. (2004) encontraram valores de PB para Massai entre $190 \mathrm{~g} \mathrm{~kg}^{-1}$ (7 dias de rebrotação) e $60 \mathrm{~g} \mathrm{~kg}^{-1}$ (42 dias de rebrotação). Fernandes et al. (2004) encontram valores de PB para lâminas foliares de capins Mombaça (87 a $168 \mathrm{~g} \mathrm{~kg}^{-1}$ ), Tanzânia (103 a $197 \mathrm{~g} \mathrm{~kg}^{-1}$ ) e Massai (98 a $179 \mathrm{~g} \mathrm{~kg}^{-1}$ ) análogos aos deste trabalho. Os menores valores de PB obtidos naquele trabalho foram para o último corte, realizado no inverno com 69 dias de crescimento. Postiglioni et al. (2004) encontraram valores menores de PB para Tanzânia (99 a $125 \mathrm{~g} \mathrm{~kg}^{-1}$ ), Mombaça (100 a $\left.130 \mathrm{~g} \mathrm{~kg}^{-1}\right)$ e Tobiatã $\left(113\right.$ a $\left.132 \mathrm{~g} \mathrm{~kg}^{-1}\right)$.

Os capins Mombaça e principalmente o Atlas foram os que acumularam menos massa de forragem. Com a adubação nitrogenada foi igual para todos os tratamentos, pode ter havido um consumo de nitrogênio que se acumulou na planta, e não foi utilizado para produção de massa pela planta. Santos (2004) afirmou que as plantas são capazes de armazenar elevados níveis de nitrato ou transportá-los de um órgão para outro, sem que isto lhe provoque nenhum dano. Balsalobre (2002) trabalhou com pastagens irrigadas de Panicum maximum cv. Tanzânia onde foi aplicado $80 \mathrm{~kg} \mathrm{~N} \mathrm{ha}^{-1}$ pastejo $^{-1}$ tanto no verão como no inverno. Ele atribuiu os maiores teores de PB no inverno (146 $\left.\mathrm{g} \mathrm{kg}^{-1}\right)$ em relação ao verão $\left(115 \mathrm{~g} \mathrm{~kg}^{-1}\right)$ a um consumo de luxo de 
nitrogênio, já que a produção de inverno foi $50 \%$ daquela obtida no verão. Kichel (2004) encontraram elevação dos teores de $\mathrm{N}$ na planta quando elevaram as doses de adubação nitrogenada em capim Massai.

A concentração de fibra em detergente neutro (FDN) foi inferior para o Atlas e igual nos demais capins e foi determinado para o capim Tanzânia o menor valor de DFDN (Tabela 18). Estes resultados, conjuntamente com os de DIVMO, DIVMS e PB indicam o capim Atlas como sendo o de melhor valor nutritivo entre os capins estudados. Balsalobre (2002) encontrou teores de FDN do capim Tanzânia (628 a 683 g $\mathrm{kg}^{-1}$ ) próximos àqueles encontrados neste trabalho. Fernandes et al.(2004) encontrou valores de FDN superiores aos deste trabalho tanto para o capim Mombaça (718 a $765 \mathrm{~g}$ $\mathrm{kg}^{-1}$ ), Tanzânia (703 a $755 \mathrm{~g} \mathrm{~kg}^{-1}$ ) e Massai (733 a $\left.786 \mathrm{~g} \mathrm{~kg}^{-1}\right)$.

Tabela 18. Concentração e digestibilidade de FDN na forragem obtida nos cortes de produção (média de todos os cortes)

\begin{tabular}{|c|c|c|}
\hline CAPIM & teor de FDN & Digestibilidade de FDN \\
\hline & $x^{2}+x^{2}$ & \\
\hline ATLAS & $664,11 \quad b$ & $432,03 \quad a$ \\
\hline MASSAI & 685,20 a & $423,68 \quad \mathrm{a}$ \\
\hline MOMBAÇA & 685,92 a & $416,02 \mathrm{ab}$ \\
\hline TANZÂNIA & 683,36 a & $388,77 \quad b$ \\
\hline TOBIAT $\tilde{A}$ & 695,58 a & 439,62 a \\
\hline EPM & 20,78 & 51,51 \\
\hline
\end{tabular}

Médias de mesma letra, na mesma coluna, não diferem entre si (Tukey, $\mathrm{P}<0,05)$

O capim que apresentou maior teor de FDA foi o Mombaça $\left(346 \mathrm{~g} \mathrm{~kg}^{-1}\right)$, superior aos valores de Atlas (333 $\mathrm{g} \mathrm{kg}^{-1}$ ) e Massai (330 $\mathrm{g} \mathrm{kg}^{-1}$ ). Os valores de FDA encontrados por Balsalobre (2002) para o P. maximum cv. Tanzânia (325 a $349 \mathrm{~g} \mathrm{~kg}^{-1}$ ) foram próximos aos encontrados neste trabalho. Os teores obtidos para o capim Tanzânia (336 $\mathrm{g} \mathrm{kg}^{-1}$ ) e o Tobiatã (335 $\mathrm{g} \mathrm{kg}^{-1}$ ) não diferiram de Atlas, Massai e Tobiatã (Tabela 19). Os valores de DFDA variaram entre 220 a $242 \mathrm{~g} \mathrm{~kg}^{-1}$ sendo o menor valor para Tanzânia e não diferindo entre os demais capins (Tabela 19). Os teores de lignina variaram entre os capins (29 a $40 \mathrm{~g} \mathrm{~kg}^{-1}$ ) sendo maiores para Mombaça e menor para Massai (Tabela 19). 
Balsalobre (2002) obteve valores de lignina variando entre 31 a $47 \mathrm{~g} \mathrm{~kg}^{-1}$. Os dados obtidos para capim Tanzânia demonstraram que esta forrageira possui valor nutritivo elevado, porém foi menor que todos os demais capins estudados, indicando que talvez o intervalo entre cortes possa ter sido elevado para este capim. Singh et al. (1995) observaram a queda da DIVMS e PB quando se aumentou o intervalo entre cortes.

Tabela 19. Concentração de FDA, digestibilidade de FDA e Lignina na forragem obtida nos cortes de produção

\begin{tabular}{|c|c|c|c|}
\hline Capim & FDA & DFDA & LIG \\
\hline & & $-\mathrm{g} \mathrm{kg}^{-1}$ & \\
\hline ATLAS & $333,30 \quad b$ & $243,48^{\circ}$ a & 38,26 \\
\hline MASSAI & 329,78 & $242,44 \quad a$ & 29,46 \\
\hline MOMBAÇA & 346,23 & $241,91 \quad$ a & 39,87 \\
\hline TANZÂNIA & 335,77 & $196,63 \mathrm{~b}$ & 35,13 \\
\hline TOBIAT $\tilde{A}$ & 335,07 & 227,79 & 30,98 \\
\hline EPM & 20,33 & 32,95 & 13,44 \\
\hline
\end{tabular}

Houve efeito de época de corte sobre a DIVMO e PB (Figura 10).Os maiores valores de DIVMO foram obtidos nos primeiros cortes e os menores nos últimos cortes (Figura 10). Os primeiros cortes foram obtidos após a implantação da área experimental e toda a forragem obtida provinha de plantas novas, de maior digestibilidade. Com o passar dos meses, houve elongação de hastes e crescimento de folhas residuais do corte anterior. Postiglioni et al. (2004) trabalharam com vários de capins de capim elefante (Pennisetum purpureum Schum) e $P$. maximum, entre eles Tobiatã, Tanzânia e Mombaça e obteve maiores produções de proteína bruta por área para estes capins no ano de implantação (1700 $\mathrm{Mg} \mathrm{ha}^{-1}$ ) que no segundo ano (850 $\left.\mathrm{Mg} \mathrm{ha}^{-1}\right)$. Gonçalves et al.(2004) encontraram maiores DIVMO no ano de implantação de capim Tobiatã $(612$ g kg $\left.{ }^{1}\right)$ que no terceiro ano $\left(603 \mathrm{~g} \mathrm{~kg}^{-1}\right)$. Santos et al. (2002) encontrou uma queda da digestibilidade de perfilhos das primeiras gerações com o aumento dos ciclos de pastejos. A primeira geração de perfilhos apresentava DIVMO de $584 \mathrm{~g} \mathrm{kg-1} \mathrm{no}$ 
primeiro ciclo de pastejo e $448 \mathrm{~g} \mathrm{~kg}^{-1}$ no quinto ciclo de pastejo. Na segunda geração de perfillhos foi obtido DIVMO de $591 \mathrm{~g} \mathrm{~kg}^{-1}$ no terceiro ciclo de pastejo e $491 \mathrm{~g} \mathrm{~kg}^{-1}$ no quinto ciclo de pastejo.Em março e abril houve florescimento dos capins, e isto pode ter influenciado a DIVMO e PB do corte subseqüente, junho de 2003. Balsalobre (2002) encontrou maiores teores de lignina e pior qualidade da fração carboidratos em forragem de $P$. Maximum cv. Tanzânia a partir do mês de maio. Este autor atribuiu esta pior qualidade da planta ao florescimento, ocorrido em várias épocas do ano, mas visualmente maior em abril, com boa parte dos perfilhos florescendo novamente em junho.

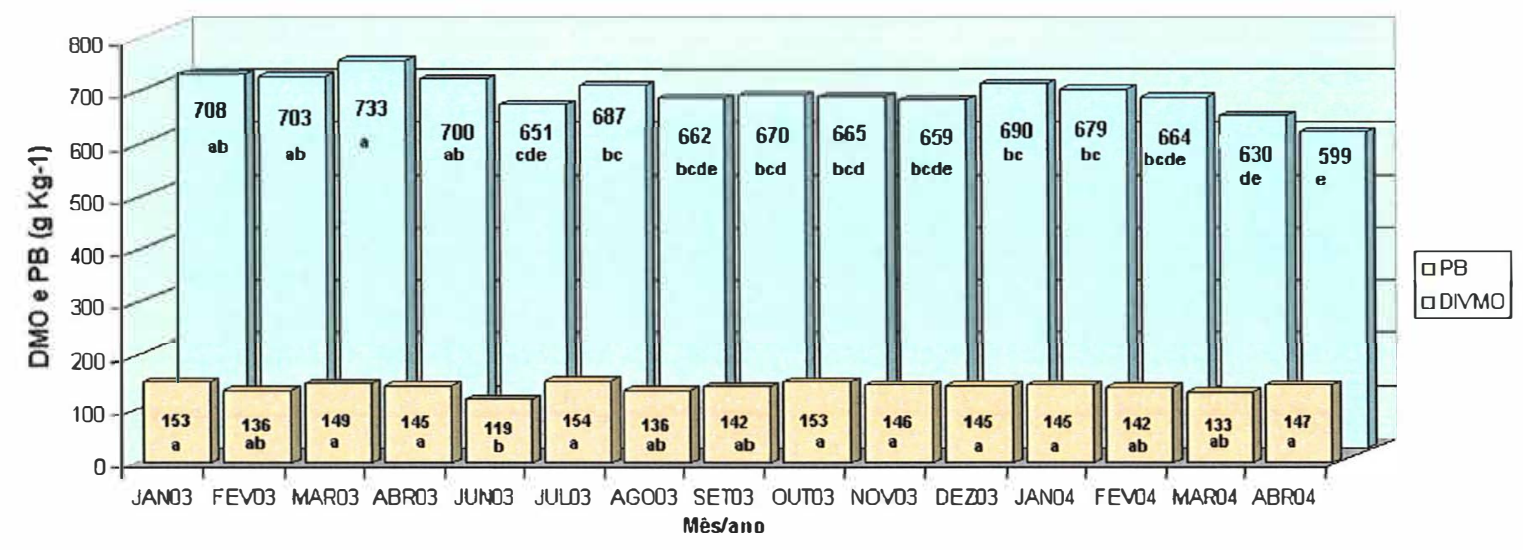

Figura 10 - DIVMO e teores de PB obtidos em diferentes cortes ao longo do período experimental (médias seguidas por mesma letra não diferem entre si, Tukey, $\mathrm{P}<0,05)$

Os valores nutritivos de plantas forrageiras podem ser afetados pelas condições climáticas a que estas estão submetidas. Fahey \& Hussein (1999) encontraram para cada um grau de aumento na temperatura, diminuição, respectivamente para o estádio vegetativo e reprodutivo de gramíneas, de 2 e $0,7 \%$ do enfolhamento, 6,5 e $0,8 \mathrm{~g} \mathrm{~kg}^{-1}$ na

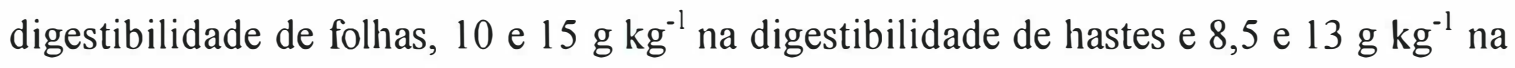
digestibilidade total. Minson \& McLeod (1970) afirmaram que o valor nutritivo de gramíneas tropicais e temperadas é mais bem explicado por diferenças genéticas e fatores climáticos que deficiências nutricionais de plantas. Para esses autores que estudaram fatores climáticos afetando Lolium perenne, Phalaris tuberosa x arundinacea, 
Cloris gayana e Setária spp. quando submetidos às mesmas condições climáticas, gramíneas tropicais e temperadas apresentam similar DIVMS. A DIVMS teve correlação com temperatura $(r=-0,76)$, evaporação $(r=-0,64)$ e ambos $(r=-0,83)$. A fim de observamos se houve também neste trabalho efeito de clima, foram feitos cortes de acompanhamento das rebrotações em dois verões e um inverno.

Durante o primeiro verão, a DIVMO da planta toda para capim Atlas foi superior à obtida para o Tanzânia (Tabela 20). Os demais capins não diferiram entre si e apresentaram valores de DIVMO semelhantes aos de Atlas e Tanzânia (Tabela 20). Para o segundo verão e inverno não houve diferença entre os capins dentro da mesma época. O capim Atlas foi o único que apresentou efeito de época sobre a DIVMO sendo maior no primeiro que no segundo verão. Os primeiros cortes foram obtidos após a implantação da área experimental e toda a forragem obtida provinha de plantas novas, de maior digestibilidade. Com o passar dos meses, houve elongação de hastes e crescimento de folhas residuais do corte anterior. Resultados parecidos foram obtidos por Postiglioni et al.(2004), Gonçalves et al.(2004) e Santos et al. (2002).

Para PB da planta toda, nos cortes de acompanhamento, não houve diferenças entre os capins nas três épocas e a média obtida entre os capins foi de $137 \mathrm{~g} \mathrm{~kg}^{-1}$. Brâncio et al. (2001) encontrou menores valores de PB para estes capins, sendo respectivamente 97, 99 e $71 \mathrm{~g} \mathrm{~kg}^{-1}$ os teores de para o capim Tanzânia, Mombaça e Massai. Em outros trabalhos, Machado et. al. (2004), Fernandes (2004) e Postiglioni et al (2004) foram obtidos valores próximos ao deste estudo. 
Tabela 20. DIVMO de planta toda obtida nos cortes finais de acompanhamento da rebrotação observados em dois verões (intervalo entre cortes de 28 dias para Atlas, Massai e Mombaça e 35 dias para Tanzânia e Tobiatã) e um inverno (intervalo entre cortes de 49 dias para Atlas, Massai e Mombaça e 63 dias para Tanzânia e Tobiatã)

\begin{tabular}{|c|c|c|c|c|}
\hline CAPIM & VERÃO 1 & VERÃO 2 & \multicolumn{2}{|c|}{ INVERNO } \\
\hline & & $-\mathrm{g} \mathrm{kg}^{-1}$ & & \\
\hline ATLAS & $738,67 \quad a$ & $663,97 \quad b$ & 672,32 & $a b$ \\
\hline MASSAI & $717,85 \quad$ ab & 665,54 & 668,08 & $a b$ \\
\hline MOMBAÇA & $685,36 \quad a b$ & $667,06 \quad a b$ & 652,56 & b \\
\hline TANZÂNIA & $655,31 \quad b$ & 690,40 & 670,51 & $a b$ \\
\hline TOBIATÃ & 701,19 ab & 666,78 & 677,23 & $a b$ \\
\hline
\end{tabular}

Médias seguidas de mesma letra, na linha ou coluna, não diferem entre si $\left(\mathrm{EPM}=57,14 \mathrm{~g} \mathrm{~kg}^{-1}\right.$,Tukey, $\left.\mathrm{P}<0,05\right)$

Os capins não diferiram entre si para DIVMS dentro da mesma estação ou entre estações (Tabela 21). O valor de DIVMS de planta toda para capim Atlas foi maior no segundo verão que o obtido no inverno e assim como para DIVMO houve efeito de estação de DIVMS para o capim Atlas. O capim Atlas tem características de crescimento diferentes dos demais capins estudados, com maior número de florescimentos e perfilhamento lateral que pode estar influenciando na variação composição morfológica e conseqüentemente sua digestibilidade. 
Tabela 21. DIVMS de planta toda obtida nos cortes finais de acompanhamento da rebrotação observados em dois verões (intervalo entre cortes de 28 dias para Atlas, Massai e Mombaça e 35 dias para Tanzânia e Tobiatã) e um inverno (intervalo entre cortes de 49 dias para Atlas, Massai e Mombaça e 63 dias para Tanzânia e Tobiatã)

\begin{tabular}{cllllll}
\hline CAPIM & \multicolumn{1}{l}{ VERÃO 1 } & VERÃO 2 & \multicolumn{1}{l}{ INVERNO } \\
\cline { 2 - 7 } ATLAS & 672,32 & ab & 738,67 & a & 663,98 & b \\
MASSAI & 652,56 & $\mathrm{~b}$ & 685,36 & ab & 667,07 & ab \\
MOMBAÇA & 668,08 & ab & 717,85 & ab & 665,55 & b \\
TANZÂNIA & 670,51 & ab & 655,32 & b & 690,41 & ab \\
TOBIATÃ & 677,23 & ab & 701,20 & ab & 666,79 & ab \\
\hline
\end{tabular}

Médias de mesma letra, na mesma coluna ou linha, não diferem entre si $(\mathrm{EPM}=54,38$, Tukey, $\mathrm{P}<0,05)$

Os teores de FDN para os capins Tanzânia e Tobiatã foram superiores ao obtidos para o capim Tanzânia no segundo verão, porém não houve diferença para os teores de FDN dos demais capins dentro de época e entre épocas (Tabela 22). Os valores de FDN obtidos foram inferiores aos obtidos por Fernandes et al. (2004) e Brâncio et al. (2001). 
Tabela 22. Teores de FDN de planta obtida nos cortes finais de acompanhamento da rebrotação observados em dois verões (intervalo entre cortes de 28 dias para Atlas, Massai e Mombaça e 35 dias para Tanzânia e Tobiatã) e um inverno (intervalo entre cortes de 49 dias para Atlas, Massai e Mombaça e 63 dias para Tanzânia e Tobiatã)

\begin{tabular}{|c|c|c|c|}
\hline CAPIM & VERÃO 1 & VERÃO 2 & INVERNO \\
\hline & \multicolumn{3}{|c|}{$\longrightarrow--\mathrm{g} \mathrm{kg}^{-1}-\ldots$} \\
\hline ATLAS & $63,91 \quad a b$ & $64,95 \mathrm{ab}$ & $64,12 \mathrm{ab}$ \\
\hline MASSAI & $66,89 \mathrm{ab}$ & $66,89 \mathrm{ab}$ & $67,33 \mathrm{ab}$ \\
\hline MOMBAÇA & $65,62 \mathrm{ab}$ & $65,15 \mathrm{ab}$ & 65,59 \\
\hline TANZÂNIA & 68,10 & $62,29 \quad b$ & $67,55 \mathrm{ab}$ \\
\hline TOBIAT $\tilde{A}$ & 67,67 & $64,31 \quad a b$ & $65,71 \quad a b$ \\
\hline
\end{tabular}

Médias de mesma letra, na mesma coluna ou linha, não diferem entre si $(\mathrm{EPM}=30,79$, Tukey, $\mathrm{P}<0,05)$

Não houve diferença entre DIVMO e PB para folhas dentro de épocas e épocas. As médias DIVMO e PB obtidas para as folhas foram, respectivamente, $670 \mathrm{~g} \mathrm{~kg}^{-1}$ e $149 \mathrm{~g} \mathrm{~kg}^{-1}$. Resultados semelhantes a estes foram obtidos por Fernandes et al. (2004).

No primeiro verão, a DIVMS de folhas para o capim Atlas foi superior àquelas obtidas para os capins Mombaça e Tanzânia (Tabela 23). Nas demais estações, os resultados de DIVMS indicam que não houve diferença entre os capins dentro da mesma época e entre épocas. . Resultados semelhantes a estes foram obtidos por Postiglioni et al. (2004). 
Tabela 23. DIVMS de folhas obtida nos cortes finais de acompanhamento da rebrotação observados em dois verões (intervalo entre cortes de 28 dias para Atlas, Massai e Mombaça e 35 dias para Tanzânia e Tobiatã) e um inverno (intervalo entre cortes de 49 dias para Atlas, Massai e Mombaça e 63 dias para Tanzânia e Tobiatã)

\begin{tabular}{|c|c|c|c|}
\hline CAPIM & VERÃO 1 & VERÃO 2 & INVERNO \\
\hline & \multicolumn{3}{|c|}{$\Longrightarrow \mathrm{g} \mathrm{kg}^{-1}$} \\
\hline ATLAS & 716,19 a & $704,55 \mathrm{ab}$ & $660,87 \mathrm{ab}$ \\
\hline MASSAI & $674,26 \mathrm{ab}$ & $663,94 a b$ & $635,40 \quad b$ \\
\hline MOMBAÇA & 645,00 & $706,70 \mathrm{ab}$ & $682,46 \mathrm{ab}$ \\
\hline TANZÂNIA & $624,65 \mathrm{~b}$ & $689,17 \quad a b$ & $699,14 \mathrm{ab}$ \\
\hline TOBIATÃ & $661,22 \mathrm{ab}$ & $690,61 \mathrm{ab}$ & $693,34 \mathrm{ab}$ \\
\hline
\end{tabular}

Médias de mesma letra, na mesma coluna ou linha, não diferem entre si $(\mathrm{EPM}=53,22$, Tukey, $\mathrm{P}<0,05)$

Os teores de FDN de folhas não apresentaram diferenças entre os capins tanto dentro da mesma época como entre épocas (Tabela 24). O teor de FDN do capim Tanzânia foi maior no invemo que no primeiro verão. Apesar de não ficar evidente para outros parâmetros analisados (DIVMO, PB e DIVMS), este maior valor de FDN de Tanzânia no inverno pode indicar que as folhas apresentavam maiores maturidades fisiológicas no inverno, onde o corte era feito a cada 63 dias enquanto que no verão foi feito a cada 35 dias. Os valores de FDN obtidos foram inferiores aos obtidos por Fernandes et al. (2004) e Brâncio et al. (2001). 
Tabela 24. Teores de FDN de folhas obtida nos cortes finais de acompanhamento da rebrotação observados em dois verões (intervalo entre cortes de 28 dias para Atlas, Massai e Mombaça e 35 dias para Tanzânia e Tobiatã) e um inverno (intervalo entre cortes de 49 dias para Atlas, Massai e Mombaça e 63 dias para Tanzânia e Tobiatã)

\begin{tabular}{ccccccc}
\hline CAPIM & VERÃO 1 & \multicolumn{2}{c}{ VERÃO 2 } & \multicolumn{2}{c}{ INVERNO } \\
\cline { 2 - 7 } ATLAS & 660,97 & ab & 652,70 & ab & 649,33 & ab \\
MASSAI & 672,85 & ab & 673,68 & ab & 679,80 & ab \\
MOMBAÇA & 673,42 & ab & 671,46 & ab & 660,16 & ab \\
TANZÂNIA & 645,41 & b & 684,89 & ab & 694,79 & a \\
TOBIATÃ & 662,81 & ab & 685,35 & ab & 676,87 & ab \\
\hline
\end{tabular}

Médias de mesma letra, na mesma coluna ou linha, não diferem entre si $(\mathrm{EPM}=30,79$, Tukey, $\mathrm{P}<0,05)$

Não houve material suficiente nas amostras de hastes e material morto para as análises. Essas frações de hastes foram combinadas entre blocos para se conseguir material suficiente para as análises químicas, perdendo-se então as repetições e não permitindo análise estatística. A DIVMO foi maior que a obtida por Brâncio et al. (2001) e inferior a obtida por Gonçalves et al. (2004) para DIVMS (Tabela 25). O teor de PB foi inferior aos obtidos por Brâncio et al (2001) e Gonçalves et al. (2004).

A DIVMO para planta toda e folhas, média de todos os capins, não diferiram, sendo igual a $681 \mathrm{~g} \mathrm{~kg}^{-1}$. O manejo dos cortes empregados, altura e intervalos entre cortes, favoreceram a presença de elevada proporção de folhas na forragem, sendo estas seu principal componente e conseqüentemente o que mais influenciou a DIVMO. O teor de $\mathrm{PB}$ foi maior para folhas $\left(148 \mathrm{~g} \mathrm{~kg}^{-1}\right)$ que para planta toda $\left(136 \mathrm{~g} \mathrm{~kg}^{-1}\right)$ que para planta toda indicando que hastes mesmo em pequenas proporções pequenas contribuiu para reduzir o teor de proteína da planta. 
Tabela 25. DIVMO média e teor médio de PB de hastes obtidos nos cortes finais de acompanhamento da rebrotação, em dois verões (intervalo entre cortes de 28 dias para Atlas, Massai e Mombaça e 35 dias para Tanzânia e Tobiatã) e um inverno (intervalo entre cortes de 49 dias para Atlas, Massai e Mombaça e 63 dias para Tanzânia e Tobiatã)

\begin{tabular}{|c|c|c|c|c|c|c|}
\hline \multirow[t]{2}{*}{ CAPIM } & \multicolumn{2}{|c|}{ VERÃO 1} & \multicolumn{2}{|c|}{ VERÃO 2} & \multicolumn{2}{|c|}{ INVERNO } \\
\hline & DIVMO & PB & DIVMO & PB & DIVMO & PB \\
\hline & & & $-\mathrm{g} \mathrm{kg}^{-1}$ & & & - \\
\hline ATLAS & 595 & 60 & 615 & 82 & 552 & 73 \\
\hline MASSAI & & & 601 & 63 & & \\
\hline MOMBACA & 661 & 71 & 596 & 74 & 497 & 73 \\
\hline TANZÂNIA & 599 & 73 & 647 & 69 & 476 & 71 \\
\hline TOBIATÃ & 632 & 74 & 632 & 69 & 532 & 61 \\
\hline
\end{tabular}

Para Massai, não houve material suficiente para as análise.

Os dados obtidos para DIVMO, PB e FDN no primeiro verão foram usados para testar regressão com variáveis de cronológicos e climáticos da planta (dias, graus dias e unidade fototérmicas) (Tabela 26). Durante o primeiro verão não foi possível estabelecer regressão entre as variáveis cronológicas e valor nutritivo para o capim Tanzânia. Para o capim Tobiatã somente FDN apresentou regressão significativa. As regressões obtidas para Atlas, Massai e Mombaça permitem estimar a queda de valor nutritivo para esses capins ( $\mathrm{P}<0,05)$, porém não houve uma variável que fosse melhor para estimar o valor nutritivo na época avaliada. Minson \& McLeod (1970) encontraram alta correlação entre temperatura e DIVMS $(r=-0,89)$. Fahey \& Hussein (1999) observaram queda da digestibilidade de folhas e hastes com o aumento da temperatura e intensidade luminosa. Teixeira Neto (1977) reportou que a digestibilidade "in vitro" da forragem de capim colonião (Panicum maximum Jacq.) caiu 0,23 unidades percentuais por dia. Perdas maiores foram registradas com capim buffel (Cenchrus ciliaris L.), quando o tempo da rebrotação variou de 42 a 84 dias, com queda média diária da digestibilidade in vitro de 0,47 unidades percentuais por dia para a planta inteira; os valores foram menores para 
folhas $(0,11$ unidades percentuais por dia) e maiores para haste $(0,62$ unidades percentuais por dia), demonstrando a maior influência das hastes na perda total de digestibilidade da forragem (Silva, 1977)

Tabela 26. Equações de regressão entre parâmetros cronológicos, climáticos e nutritivos de Panicum spp.

\begin{tabular}{|c|c|c|c|c|c|}
\hline CAPIM & $\begin{array}{c}\text { VARIÁVEL } \\
\text { CRONOLÓGICA }\end{array}$ & $\begin{array}{c}\text { VARIÁVEL } \\
\text { DEPENDENTE }\end{array}$ & EQUAÇÃO & $\mathbf{R}^{2}$ & $\begin{array}{c}\text { Significância } \\
(\mathrm{P}<\mathrm{x})\end{array}$ \\
\hline Mombaça & Dia & $\mathrm{PB}$ & $Y=21,249-0,3198 x$ & 0,83 & 0,0001 \\
\hline Mombaça & GD & PB & $Y=20,618-0,0458 x$ & 0,83 & 0,0001 \\
\hline Atlas & Dia & PB & $Y=22,4441-0,3894 x$ & 0,82 & 0,0001 \\
\hline Atlas & GD & PB & $Y=21,785-0,0468 x$ & 0,82 & 0,0001 \\
\hline Atlas & UF & PB & $Y=19,262-0,0015 x$ & 0,79 & 0,0001 \\
\hline Mombaça & UF & PB & $Y=18,559-0,0018 x$ & 0,77 & 0,0001 \\
\hline Atlas & GD & $\mathrm{DMO}$ & $Y=87,319-0,095 x$ & 0,58 & 0,001 \\
\hline Atlas & Dia & DMO & $Y=88,573-0,7919 x$ & 0,57 & 0,0011 \\
\hline Atlas & UF & DMO & $Y=82,255-0,0032 x$ & 0,57 & 0,0011 \\
\hline Massai & Dia & FDN & $Y=55,919+0,528 x$ & 0,46 & 0,0024 \\
\hline Massai & GD & FDN & $Y=56,756+0,0591 x$ & 0,45 & 0,0026 \\
\hline Tobiatã & GD & FDN & $Y=60,677+0,0261 x$ & 0,43 & 0,0019 \\
\hline Massai & UF & FDN & $Y=60,18+0,0018 x$ & 0,42 & 0,0039 \\
\hline Tobiatã & Dia & FDN & $Y=59,98+0,2005 x$ & 0,42 & 0,0022 \\
\hline Tobiatã & UF & FDN & $Y=62,022+0,0009 x$ & 0,37 & 0,0044 \\
\hline Atlas & UF & FDN & $Y=62,156+0,001 x$ & 0,36 & 0,0139 \\
\hline Atlas & GD & FDN & $Y=60,722+0.0299 x$ & 0,32 & 0,0213 \\
\hline Atlas & Dia & FDN & $Y=60.446+0,2412 x$ & 0,29 & 0,0268 \\
\hline Mombaça & Dia & FDN & $Y=62,259+0,2644 x$ & 0,28 & 0,0196 \\
\hline Mombaça & GD & FDN & $Y=62,79+0,0378 x$ & 0,28 & 0,0203 \\
\hline Mombaça & UF & FDN & $Y=64,476+0,0015 x$ & 0,26 & 0,0243 \\
\hline Massai & Dia & DMO & $Y=81,114-0,5331 x$ & 0,22 & 0,0376 \\
\hline Massai & GD & DMO & $Y=80,112-0,0586 x$ & 0,21 & 0,0432 \\
\hline Massai & UF & DMO & $Y=76,627-0,0017 x$ & 0,18 & 0,0557 \\
\hline
\end{tabular}




\section{CONCLUSÕES}

O capim Massai possui produtividade elevada, igual ou superior aos demais capins estudados, tanto no verão como no inverno, grande proporção de folhas na massa de forragem no momento do corte ou pastejo e conseqüentemente pequena proporção de hastes e material morto, tem valor nutritivo similar a outros cultivares, sendo uma alternativa de plantio aos atuais capins Tanzânia e Mombaça para o estabelecimento de pastagens de Panicum spp.

O capim Atlas tem produtividade muito inferior aos demais capins de Panicum $s p p$, tanto no verão como no inverno, não se constituindo em alternativa às capins adotadas atualmente para elevação da produtividade, porém foi o que apresentou maior valor nutritivo.

As alturas de corte e intervalos entre cortes adotados no experimento proporcionaram forragem colhida com alta proporção de folhas e elevada produção de matéria seca durante a rebrotação, podendo ser adotados em sistemas pastoris que exploram estas forragens.

A avaliação física da forragem permite a caracterização e diferenciação dos capins de $P$. maximum e seus componentes, porém apenas resistência ao cisalhamento, tamanho médio de partículas e resistência à moagem se mostraram eficientes para caracterizar cultivares e seus componentes morfológicos, indicando que estas avaliações podem ser usadas em programas de melhoramento e na caracterização de alimentos advindo de pastagens.

Resistência ao cisalhamento apresentou correlação com parâmetros químicobromatológicos, podendo ser uma avaliação indicativa do valor nutritivo de forragens. 
O valor nutritivo do capim Atlas foi o maior entre os capins estudados enquanto que o Tanzânia apresentou menor valor nutritivo.

A época de corte ou estação de crescimento teve influência no valor nutritivo dos capins estudados.

O valor nutritivo de folhas não variou entre capins e foi superior ao de hastes.

O valor nutritivo de Panicum spp. está mais relacionada com a presença de hastes na massa total de forragem que com diferenças de genótipos.

O valor nutritivo diminuiu com a maturidade da planta e esta queda pode ser estimada para os capins Atlas, Massai, Mombaça e Tobiatã através de equações de regressão que relacionem tanto variáveis cronológicas (dias de crescimento) com climáticas (graus dias ou unidade fototérmica). 


\section{REFERÊNCIAS BIBLIOGRÁFICAS}

AKIN, D.E; BURDICK, D. Percentage of tissues types in tropical and temperate grass leaf blades and degradation by rumen microorganisms. Crop Science. v.15, p. 661$668,1975$.

AKIN, D.E.; FALES, S.L.; RIGSBY, L.L.; SNOOK, M.E. Temperature effects on leafs anatomy, phenolic acids and tissue disgestibility in tall fescue. Agronomy Journal v. $79, \mathrm{p} 271-275,1987$

AKIN, D.E.; RIGSBY, L.L.; LYON, C.E.; WINDHAM, W.R. Relationship of tissue digestion to textural strength in Bermuda grass and alfalfa stems. Crop Science, v. 30, p. 990-993, 1990.

AKIN, D.E.; KIMBALL, B.A.;WINDRAM, W.R.; PINTER Jr, P.J.; WALL, G.W.; GARCIA, R.L.; LaMORTE, R.L; MORRISON III, W.H. Effect of free-air CO2 enrichment (FACE) on forage quality of wheat. Animal feed Science and Technology. v. 53, p. 29-43, 1995.

ARONOVICH, S. O capim colonião e outros cultivares de Panicum maximum (Jacq.): Introdução e evolução do uso no Brasil. In: SIMPÓSIO DE MANEJO DE PASTAGENS - O CAPIM COLONIÃO, 12., Piracicaba, 1995. Anais. Piracicaba: FEALQ, 1995. p.1-20.

BALSALOBRE, M.A.A. Valor alimentar do capim Tanzânia irrigado. Piracicaba, 2002. 113p. Tese (Doutorado) - Escola Superior de Agricultura "Luiz de Queiroz", Universidade de São Paulo.

BERZAGHI, P.; COZZI, G.; ANDRIGHETTO, I. The use of near infrared analysis for in situ studies. Journal of Dairy Science, v.80, p.3263-3270, 1997.

BOTREL, M.A.; ALVIM, M.J.; XAVIER, D.F. Efeito da irrigação sobre algumas características agronômicas de cultivares de Capim elefante. Pesquisa Agropecuária Brasileira, v.26, p. 1731-1736, 1992. 
BRÂNCIO, P.A.; NASCIMENTO JÚNIOR, D.; EUCLIDES, V.P.B.; REGAZZI, J.A. ALMEIDA, R.G.; FONSECA, D.M. Valor nutritivo da forragem disponível e da dieta selecionada por bovinos em pastagens de cultivares de Panicum maximum Jacq. In: REUNIÃO ANUAL DA SOCIEDADE BRASILEIRA DE ZOOTECNIA, 38., Piracicaba, 2001. Anais. Piracicaba: SBZ, 2001. p.222-223.

BRÂNCIO, P.A.; EUCLIDES, V.P.B.; NASCIMENTO JÚNIOR, D.; FONSECA, D.M.; ALMEIDA, R.G.; MACEDO, M.C.M.; BARBOSA, R.A.. Avaliação de três cultivares de Panicum spp. sob pastejo: disponibilidade de forragem, altura do resíduo pós-pastejo e participação de folhas, colmos e material morto. Revista Brasileira de Zootecnia, v.32, n. 1, p.55-63, 2003a.

BRÂNCIO, P.A.; NASCIMENTO JÚNIOR, D.; EUCLIDES, V.P.B.; FONSECA, D.M.; ALMEIDA, R.G.; MACEDO, M.C.M.; BARBOSA, R.A.. Avaliação de três cultivares de Panicum spp. sob pastejo: Composição da dieta, consumo de material seca e ganho de peso animal. Revista Brasileira de Zootecnia, v.32, n.5, p.1037$1044,2003 b$.

BRITO, C.J.F.A.; ALQUINI, Y.; RODELLA, R.A.; DESCHAMPS, F.C. Alterações histológicas de três ecotipos de capim-elefante (Pennisetum purpureum Schum.) após digestão in vitro. In: REUNIÃO ANUAL DA SOCIEDADE BRASILEIRA DE ZOOTECNIA, 34., Juiz de Fora, 1997. Anais. Juiz de Fora: SBZ, 1997a. p.12-14.

BRITO, C.J.F.A.; ALQUINI, Y.; RODELLA, R.A.; DESCHAMPS, F.C. Perfil anatômico dos tecidos de três ecotipos de capim-elefante (Pennisetum purpureum Schum.). In: REUNIÃO ANUAL DA SOCIEDADE BRASILEIRA DE ZOOTECNIA, 34., Juiz de Fora, 1997. Anais. Juiz de Fora: SBZ, 1997b. p.9-11.

BRITO, D.P.P.S.; ARONOVICH, S.; RIBEIRO, H. Comparação entre 2 variedades de capim-elefante (Pennisetum purpureum, SCHUM.) e de 6 diferentes espaços de tempo entre cortes de plantas. In: INTERNATIONAL GRASSLAND CONGRESS, 9., São Paulo, 1962. Proceedings. São Paulo, 1962. p. 1683-1685.

BUENO, A.A. O. Características estruturais do dossel forrageiro, valor nutritivo e produção de forragem nos pastos de capim-mombaça submetidos a regimes de lotação intermitente. Piracicaba, 2003. Disssertação (Mestrado). Escola Superior de Agricultura 'Luiz de Queiroz'.

BURNS, J.C.; FISHER D.S.; POND, K.R.; TIMOTHY D.H. Diet characteristics, digesta kinetics, and dry matter intake of steers grazing eastern gamagrass. Journal of Animal Science, v.70, p. 1251-1261, 1992. 
BUXTON, D.R.; CASLER, M.D. Environmental and genetic effects on cell wall composition and digestibility. In: JUNG, H.G.; BUXTON, D.R.; HATFIELD, R.D.; RALPH, J. (Ed.). Forage cell wall structure and digestibility. Madison: ASA; CSSA; SSSA, 1993.p. 685-714.

BUXTON, D.R.; FALES, S.L. Plant environment and quality, In: FAHAY JR., G. C.; COLLINS, M.; MERTENS, D.R.; MOSER, L.E. (Ed.). Forage quality. Lincoln: ASA; CSSA; SSSA, 1994. p. 155-199.

CASLER, M.D. Breeding forage crops for increased nutritional value. Advances in Agronomy, v 71, p. 51-107, 2001.

CASLER, M.E.; JUNG, H.G. Selection and evaluation of Smooth Brome grass clones with divergent lignin or etherified ferulic acid concentration. Crop Science. v. 39, p. 1866-1873, 1999.

CECATO, U.; MACHADO, A.O.; MARTINS, E.N.; PEREIRA, L.A.F.; BARBOSA, M. A.A.F.; SANTOS, G.T. Avaliação da produção e de algumas características da rebrota de cultivares e acessos de Panicum maximum Jacq. sob duas alturas de corte. Revista Brasileira de Zootecnia, v. 29, n. 3, p.660-668, 2000.

CORSI, M. Estudo da produtividade e do valor nutritivo do capim-elefante (Pennisetum purpureum Schum.), variedade napier submetido a diferentes freqüências e alturas de corte. Piracicaba, 1972. Tese (Doutorado) - Escola Superior de Agricultura "Luiz de Queiroz", Universidade de São Paulo.

CORSI, M. Espécies forrageiras em pastagens. In: SIMPÓSIO SOBRE MANEJO DE PASTAGEM, 6., Piracicaba, 1976. Anais. Piracicaba: ESALQ, 1976. p. 5-36.

CORSI, M.; AGUIAR, R.N.; MENEZES, M. 30 anos do Simpósio sobre Manejo de Pastagens. In: SIMPÓSIO SOBRE MANEJO DE PASTAGEM, 21., Piracicaba, 2004. Anais. Piracicaba: FEALQ, 2004. p. 473-480.

COX, W. J., KALONGE, S., CHERNEY, D. J. R., REID, W. S. Growth, yield and quality of forage maize under different nitrogen management practices. Agronomy Journal. v. 85, p. 341-347, 1993.

COZZOLINO, D.; ACOSTA, Y.; GARCIA, J. Application of near infrared reflectance spectroscopy (NIRS) to forage evaluation in Uruguay. In: INTERNATIONAL GRASSLANDS CONGRESS, 19., São Pedro, 2001. Proceedings. Piracicaba: FEALQ, 2001.p.370.

DESCHAMPS, F.C. Implicações do período de crescimento na composição química e digestão dos tecidos de cultivares de capim-elefante (Pennissetum purpureum Schum.). Revista Brasileira de Zootecnia, v.28, n.6, p.1358-1369, 1999. 
DIAS-FILHO, M. B. Colonião como planta pioneira. In.: SIMPÓSIO DE MANEJO DE PASTAGENS - O CAPIM COLONIÃO, 12., Piracicaba, 1995. Anais. Piracicaba: FEALQ, 1995. p. 305-314.

DUBEUX JR, J.C.B., SANTOS, H.Q, SOLLENBERGER, L.E. Ciclagem de nutrientes: Perspectivas de aumento da sustentabilidade da pastagem manejada intensivamente. In: SIMPÓSIO SOBRE MANEJO DE PASTAGEM, 21., Piracicaba, 2004. Anais. Piracicaba: FEALQ, 2004. p. 357-400.

EUCLIDES, V.P.B.; ZIMMER, A.H.; OLIVEIRA, M.P. Evaluation of Brachiaria decumbens and Brachiaria brizantha under grazing. In: INTERNATIONAL GRASSLAND CONGRESS, 17., Rock Hampton, 1993. Proceedings. Palmerston North: New Zealand Grassland Association, 1993. p.1997-1998.

EUCLIDES, V. P. B Valor alimentício de espécies do gênero Panicum. In.: SIMPÓSIO DE MANEJO DE PASTAGENS - O CAPIM COLONIÃO, 12., Piracicaba, 1995. Anais. Piracicaba: FEALQ, 1995. p. 245-273.

FALES, S. L. Effects of temperature on Fiber concentration, composition, and in vitro digestion kinetics of tall fescue. Agronomy Journal, v. 78:963-966, 1986.

FARIA, V.P.; PEDREIRA, C.G.S.; SANTOS, F.A.P. Evolução do uso de pastagens para bovinos. In: SIMPÓSIO SOBRE MANEJO DA PASTAGEM, 13., Piracicaba, 1996. Anais. Piracicaba: FEALQ, 1996. p. 1-14.

FERNANDES, F.D; MARTHA JUNIOR, G.B.; RAMOS, A.K.B.; JANK, L.; VILELA, L.; KARIA, C.T.; ANDRADE, R.P. FALEIRO, F.G. Valor Nutritivo de acessos de Panicum maximum Jacq. No distrito federal (compact disc). In: REUNIÃO ANUAL DA SBZ, 41., Campo Grande, 2004. Anais: Resumos. Campo Grande: SBZ, 2004.

FLORES, J.A.; MOORE, J.E.; SOLLENBERGER, L.E. Determinants of forage quality in Pensacola bahiagrass and Mott elefantgrass. Journal of Animal Science, v.71, pl.606-1614, 1993.

FUNDAÇÃO INSTITUTO BRASILEIRO DE GEOGRAFIA E ESTATÍSTICA. Censo Agropecuário 1995-1996. Número 19 - São Paulo. Rio de Janeiro: IBGE, 1998.

FUNDAÇÃO INSTITUTO BRASILEIRO DE GEOGRAFIA E ESTATÍSTICA. Produção da pecuária municipal 2002. Rio de Janeiro: IBGE, 2002.v. 30, 29 p.

FURTADO, R. Agribusiness brasileiro: a história. São Paulo: Evoluir, 2002. 225 p. 
GERDES, L.; WERNER, J.C.; FERREIRA, T.A.; BARDUIL, A.; BEISMAN, D.A. Produção de matéria seca e algumas características morfológicas de três capins em três idades de corte (compact disc). In: REUNIÃO ANUAL DA SOCIEDADE BRASILEIRA DE ZOOTECNIA, 35., Botucatu, 1998. Anais. Botucatu: SBZ. 1998.

GIGER-RIVERDIN, S. Characterization of feedstuffs for ruminants using some physical parameters. Animal Feed Science and Technology, v. 82, p. 53-69, 2000.

HENDRICKSON, J. E.; MOSER, L. E.; MOORE, K. J.; WALLER, S. S. Leaf nutritive value related to tiller development in warm-season grasses. Journal of Ranger Management, v. 50, n. 2, p. 116-122, 1997.

HENRY, D.A; MACMILLAN, R.H.; SIMPSON; R.J. Measurement of shear and tensile fracture properties of leaves of pasture grasses. Australian Journal of Agricultural Research, v. 47, p. 587-603, 1996.

HERRERA SOTO, H.A. Um modelo simples de estimativa de produção de forragem para colonião (Panicum maximum (Jacq.)) e pangola (A-24 Digitaria pentzii Stent.) usando parâmetros climáticos. Piracicaba, 1981. 58 p. Dissertação (Mestrado) Escola Superior de Agricultura Luiz de Queiroz, Universidade de São Paulo

HUGHES, R.G.; VALLE, C.B.; HERRERO, M. Estimativa de resistência ao cisalhamento e à moagem em quatro espécies de Brachiaria. In: REUNIÃO ANUAL DA SOCIEDADE BRASILEIRA DE ZOOTECNIA, 35., Botucatu, 1998. Anais. Botucatu: SBZ, 1998. p.43-45.

HUGHES, R.G.; VALlE, C.B.; SABATEL, V.; BLOCK, J.; JESSOP, N.S.; HERRERO, M. Shearing strength as an additional selection criterion for quality in Brachiaria pastures ecotypes. Journal of Agricultural Science, v. 135, p. 123-130, 2000.

IWAASA, A.D.; BEAUCHEMIN, A.J.; ACHARYA, S.N.; BOWLEY, S.R.; BUCHANAN-SMITH, J.G.; Shearing force of alfafa stems as affected by seeding rate. Canadian Journal of Plant Science, v. 78, p.273-280, 1997.

IWAASA, A.D.; BEAUCHEMIN, A.J.; ACHARYA, S.N.; BUCHANAN-SMITH, J.G.; Shearing force of alfafa stems: effects of genotypes and year interactions. Canadian Journal of Plant Science, v. 78, p.719-722, 1998.

JANK, L.; SAVIDAN, Y.; SOUZA, M. T.; COSTA, J. C. G. Avaliação do germoplasma de Panicum maximum introduzido da África. 1. Produção forrageira. Revista Sociedade Brasileira de Zootecnia, v. 23, p.433-440, 1994. 
JANK, L. Melhoramento e seleção de variedades de Panicum maximum. In.: SIMPÓSIO DE MANEJO DE PASTAGENS - O CAPIM COLONIÃO, 12., Piracicaba, 1995. Anais. Piracicaba: FEALQ, 1995. p. 21-58.

JUNG, H. G., BUXTON, D. R. Forage quality variation among maize inbreeds: relationships of cell-wall composition na in vitro degradability for stem internodes. Journal of Science of Food and Agriculture, v. 66, p. 313-322, 1994.

JUNG, H. G.; MERTENS, D.R.; BUXTON, D.R. Forage quality variation among maize inbreeds: in vitro fiber digestion kinetics and prediction with NIRS. Crop Science, v.38, p. 205-210, 1998.

KICHEL, A.G.; MIRANDA, C.H.B; LEMPP, B. Acúmulo de material seca e nitrogênio e perfilhamento de Panicum maximum cv. Massai em função de doses crescents de nitrogênio. In: REUNIÃO ANUAL DA SOCIEDADE BRASILEIRA DE ZOOTECNIA, 41., Campo Grande, 2004. Anais: Resumos. Campo Grande: SBZ, 2004.

KLEPPER, B.; RICKMAN, R. W.; PETERSON, C. M. Quantitative characterization of vegetative development in small cereal grains. Agronomy Journal, v.74, p.789-792, 1982.

LEMPP, B.; KICHEL, A.G.; MIRANDA, C.H.B; GOMES, R.A; SILVA, E.B.A. Proporção e arranjo de tecidos em lâminas foliares de Panicum maximum cv. Massai (compact disc). In: REUNIÃO ANUAL DA SOCIEDADE BRASILEIRA DE ZOOTECNIA, 41., Campo Grande, 2004. Anais: Resumos. Campo Grande: SBZ, 2004.

LENSSEN, A.W.; SORENSEN, E.L.; POSLER, G.L.; BLODGETT, S.L. Depression of forage quality of alfafa leaves and stems by Acyrthosiphon kondoi (Homóptera: Aphididae). Annals of the Entomological Society of America, v. 20, n. 1, p.71-76, 1991.

LUPINACCI, A.V. Lançamento de cultivares de plantas forrageiras: uma visão crítica In: SIMPÓSIO SOBRE MANEJO DE PASTAGEM, 30., Piracicaba, 2003. Anais. Piracicaba: FEALQ, 2003.p. 83-104.

MACHADO, A.O.; CECATO, U.; MIRA, R.T.; PEREIRA, L.A.F.; DAMASCENO, J. C. Avaliação da composição química e digestibilidade in vitro da matéria seca de cultivares e acessos de Panicum maximum Jacq. sob duas alturas de corte. Revista Brasileira de Zootecnia, v. 27, n. 5, p.1057-1063, 1998. 
MACHADO, F.A; NASCIMENTO, M.P.S.C.B.; NASCIMENTO, H.T.S.; OLIVEIRA, M.E.; LEAL J.A. Produtividade e valor nutritivo do capim Massai, a diferentes idades, no meio-norte do Brasil (compact disc). In: REUNIÃO ANUAL DA SOCIDADE BRASILEIRA DE ZOOTECNIA, 41., Campo Grande, 2004. Anais: Resumos. Campo Grande: SBZ, 2004.

MAGALHÃES, L.J.; CARNEIRO, J.C.; CAMPOS, D.S.; MAURÍCIO; R.M., ALVIM; M.J.; XAVIER; D.F. Composição química, digestibilidade e fracionamento do nitrogênio e dos carboidratos de algumas espécies forrageiras. Pasturas Tropicales, v.25, n. 1, p. 33-36, 2002.

MACKINNON, B.W.; EASTON, H.S.; BARRY, T.N.; SEDCOLE, J.R; The effect of reduced leaf shear strength on the nutritive value of perennial ryegrass. Journal of Agricultural Science, v. 111, p.469-474, 1988.

MINSON, J.D.; McLEOD, M.N. The digestibility of temperate and tropical grasses In: INTERNATIONAL GRASSLAND CONGRESS, 11., Surfers Paradise, 1970. Proceedings. Queensland, 1970. p.719-722.

MINSON, J.D.; WILSON, J.R. Prediction of intake as an element of forage quality. ln: FAHEY JR., G.C.; COLLINS, M.; MERTENS, D.R.; MOSER, L.E. (Ed.). Forage quality, evaluation and utilization. Madison: American Society of America, 1994. cap. 4, p.533-563.

MONTEIRO, F.A. Cynodon: Exigências minerais e adubação. In: WORKSHOP SOBRE O POTENCIAL FORRAGEIRO DO GÊNERO CYNODON, Juiz de Fora, 1996. Anais. Coronel Pacheco: CNPGL, EMBRAPA, 1996. p. 23-44.

MORENO, L.B.S. Produção de forragem de capins do gênero Panicum e modelagem das respostas produtivas e morfofisiológicas em função de variáveis climáticas. Piracicaba, 2004. 86 p. Dissertação (Mestrado) - Escola Superior de Agricultura "Luiz de Queiroz", Universidade de São Paulo.

MÜLLER, M.S. Desempenho de Panicum maximum (Jacq.) (cv. Mombaça) em pastejo rotacionado, sob sistema de irrigação por pivô central, na região de cerrado. Piracicaba, 2000. 101 p. Dissertação (Mestrado) - Escola Superior de Agricultura "Luiz de Queiroz", Universidade de São Paulo.

PACIULLO, D.S.C.; GOMIDE, J.A.; SILVA, E.A.M.; QUIROZ, D.S.; GOMIDE, C.A.M. Degradação in vitro de tecidos de lâmina foliar e de colmo de gramíneas forrageiras tropicais, em função do estádio de desenvolvimento. Revista Brasileira de Zootecnia, v.31, n. 2, p.900-907, 2002. 
PARSONS, J. J. Spread of African pasture grasses of the american tropics. Journal of Ranger Manegement, v.25, n.1, p. 12-17, 1972.

PEDREIRA, C.G.S.; MELLO, A.C.L.; OTANI, L. O processo de produção de forragem em pastagem. In: MATTOS, W.R.S.; PEDREIRA, C.G.S.; SILVA, S.C.(Ed.). A produção animal na visão dos brasileiros. Piracicaba: FEALQ, 200 1. p. 772-807.

PEDREIRA, J.V.S. Crescimento estacional dos capins colonião (Panicum maximum (Jacq.), gordura (Melinis minutiflora Pal de Beauv.), jaraguá (Hyparrhenia rufa [Ness] Stapf.) e pangola de Taiwan A-24 (Digitaria pentzii Stent.). Piracicaba, 1972. 117 p. Tese (Doutorado) - Escola Superior de Agricultura Luiz de Queiroz, Universidade de São Paulo

PEDREIRA, J.V.S.; MATTOS, H.B. Crescimento estacional de vinte e cinco espécies ou variedades de capins. Boletim de Indústria Animal, v.38, n.2, p. 117 - 143, 1981 .

PENATI, M. A. Estudo do desempenho animal e produção do capim Tanzânia (Panicum maximum Jacq.) em um sistema rotacionado de pastejo sob irrigação em três níveis de resíduo pós-pastejo. Piracicaba, 2002. 115 p.Tese (Doutorado) - Escola Superior de Agricultura 'Luiz de Queiroz' - Universidade de São Paulo.

PINHEIRO, J.S. Curva de crescimento e valor nutritivo do capim-jaraguá (Hiparrenia rufa (ness) Stapf). Viçosa, 1975. Tese (Doutorado) - Universidade Federal de Viçosa.

POND, K.R.; ELLIS, W.C.; LASCANO, C.E., AKIN, D.E. Fragmentation and flow of grazed coastal Bermuda grass through the digestive tract of cattle. Journal of Animal Science, v. 65, p.609-618, 1987.

POSTIGLIONI, S.R.; GARCIA SÁ, J.P.; LEME, M.C.J. Flutuação dos valores Protéicos e da digestibilidade in vitro da matéria seca verde de cultivares de Panicum e capim elefante submetidos a pastejo nos campos gerais do Paraná (compact disc). In: REUNIÃO ANUAL DA SOCIEDADE BRASILEIRA DE ZOOTECNIA, 41., Campo Grande, 2004. Anais: Resumos. Campo Grande: SBZ, 2004.

PRADO, I. N.; MOREIRA, F.B.; CECATO, U; WADA, F.Y.;OLIVEIRA. E.; REGO, F.C.A. Sistemas para crescimento e terminação de bovinos de corte a pasto: avaliação do desempenho animal e características da forragem. Revista Brasileira de Zootecnia, v.32, n.4, p.955-965, 2003

QUEIROZ FILHO, J.L.; SILVA, D.S; NASCIMENTO, I.S. Produção de material seca e qualidade de capim-elefante (Penniseum purpureum Schum.) cultivar roxo em diferentes idades de corte. Revista Brasileira de Zootecnia, v.29, n. 2, p.69-74, 2000. 
REID, R. L.; POST, A. J.; OLSEN, F. J.; MUGERWA, J. S. Studies on the nutritional quality of grasses and legumes in Uganda. I - Application of in vitro digestibility techniques to species and stages of growth effects. Tropical Agriculture, v.50, p. 1-16, 1973.

ROLIM, F.A. Estacionalidade de produção de forrageiras. In: SIMPÓSIO SOBRE MANEJO DA PASTAGEM, 6., Piracicaba, 1980. Anais. Piracicaba, FEALQ, 1980. .p. 39-81.

ROSSETO, F. A. A. Desempenho agronômico de pastagens de capim elefante cv. Guaçu (Pennisetum purpureum Schum.) e capim Tanzânia (Panicum maximum Jacq.) em sistemas de produção de leite. Piracicaba, 2000. 174 p. Dissertação (Mestrado) Escola Superior de Agricultura 'Luiz de Queiroz' - Universidade de São Paulo.

RUFFIER, F. Manual prático de criação de gado no Brasil. São Paulo: Ed. Chácaras e quintales, 1918. p.36-73.

SANTOS, P.M.; CORSI, M.; BALSALOBRE,M.A.A. Efeito da freqüência de pastejo e da época do ano sobre a produção e a qualidade em Panicum maximum (Jacq.) cvs. Tanzânia e Mombaça. Revista Brasileira de Zootecnia, v.28, n. 2, p.244-249, 1999.

SANTOS, P.M. Aspéctos fisiológicos e metabólicos da nutrição nitrogenada de plantas forrageiras. In: SIMPÓSIO SOBRE MANEJO DE PASTAGEM, 21., Piracicaba, 2004. Anais. Piracicaba: FEALQ, 2004. p. 139-154.

SAS INSTITUTE. SAS/STAT: user's guide, version 6. 4.ed. Cary, 1989. v.2, 846p.

SAVIDAN, Y.H.; JANK, L.; COSTA, J.C.G. Registro de 25 acessos selecionados de Panicum maximum. Campo Grande: EMBRAPA, CNPGC, 1990. 68p. (EMBRAPA. CNPGC. Documentos, 44).

SEMAN, D.H.; FRERE,M.H.; STUEDEMANN, J.A.; WILKINSON, S.R. Simulating the influence of stocking rate, sward height and density on steer productivity and grazing behavior. Agricultural Systems, v.37, p.165-181, 1991.

SILVA, U.R da. Produtividade, valor nutritivo e características morfológicas do capim buffel. Viçosa, 1977. 62 p. Tese (M.S.) - Universidade Federal de Viçosa.

SINCLAIR, T.R.; SELLIGMAN, N.G. Global environment change and simulated forage quality of wheat. I. Nonstressed conditions. Field Crops Research. v. 40, p. 19-27, 1995. 
SINGH, D.K.; SINGH, V.; SALE, P.W.G. Effect of cutting management on yield and quality of different selections of Guinea grass (Panicum maximum (Jacq.) in a humid subtropical environment. Tropical Agriculture, v.72, n.3, p.181-187, 1995.

SOIL SURVEY STAFF. Keys to soil taxonomy. 4.ed. Blacksburg: Virginia Polytechnic Institute State University Press, 1990. 422 p. (Soil Management Support Services Technical Monograph, 19).

SOLLENBERGER, L.E.; BURNS, J.C. Canopy characteristics, ingestive behavior and herbage intake in cultivated tropical grasslands. In: INTERNATIONAL GRASSLANDS CONGRESS, 19., São Pedro, 2001. Proceedings. Piracicaba: FEALQ, 2001.

TEIXEIRA, E. I. Avaliação de características morfofisiológicas e nutricionais do capim Tobiatã (Panicum maximum cv. Tobiatã) sob sistema de pastejo rotacionado. Piracicaba, 1998. 87 p. Dissertação (Mestrado) - Escola Superior de Agricultura 'Luiz de Queiroz' - Universidade de São Paulo.

TEIXEIRA NETO, J.F. Produtividade e valor nutritivo do capim-colonião (Panicum maximum Jacq.) durante a estação de pastejo. Viçosa, 1977. 43 p. Tese (M.S.) Universidade Federal de Viçosa.

TOSI, P. Estabelecimento de parâmetros agronômicos para o manejo e eficiência de utilização de Panicum maximum Jacq. cv Tanzânia 1 sob pastejo rotacionado. Piracicaba, 1999. 103 p. Dissertação (Mestrado) - Escola Superior de Agricultura 'Luiz de Queiroz' - Universidade de São Paulo.

UEBELE, M. C. Padrões demográficos de perfilhamento e produção de forragem do capim Mombaça em pastos submetidos regimes de lotação intermitente. Piracicaba, 2002. 83 p. Dissertação (Mestrado) - Escola Superior de Agricultura 'Luiz de Queiroz' - Universidade de São Paulo.

VENTRELlA, M.C.; RODELlA, R.A.; COSTA, C., CURI, P.R. Anatomia e bromatologia de espécies forrageiras de Cynodon rich. I - Folha. In: REUNIÃO ANUAL DA SOCIEDADE BRASILEIRA DE ZOOTECNIA, 34., Juiz de Fora, 1997. Anais. Juiz de Fora: SBZ, 1997. p.3-5.

VILLA NOVA, N.A.; BARIONI, L.G.; PEDREIRA, C.G.S.; PEREIRA, A.R. Modelo para previsão da produtividade do capim-elefante em função de temperatura do ar, fotoperíodo e freqüência de desfolha. Revista Brasileira de Agrometeorologia, v.7, n.1, p.75-79, 1999.

WATSON, J. M. Genetic engineering of low-lignin pasture plants. In: AKIN et al. (Ed.). Genetic engineering of plants. Camberra: Elsevier, 1990. p. 215-225. 
WILSON, J.R. Environmental and nutritional factors affecting herbage quality. In: HACKER, J.B. (Ed.). Nutritional limits to animal productions from pastures. Farnham: CAB. 1982. p. 111-131. 